\title{
BUTCHER AND BOLT: \\ CANADIAN TRENCH RAIDING DURING THE GREAT WAR, 1915-1918
}

\author{
by
}

Colin David Garnett, B.A. (Hons.)

\begin{abstract}
A thesis submitted to the Faculty of Graduate and Postdoctoral Affairs in partial fulfillment of the requirements for the degree of

Master of Arts

in

History
\end{abstract}

Carleton University

Ottawa, Ontario

(C) 2011

Colin David Garnett 
Library and Archives

Canada

Published Heritage

Branch

395 Wellington Street

Ottawa ON K1A ON4

Canada
Bibliothèque et

Archives Canada

Direction du

Patrimoine de l'édition

395 , rue Wellington

Ottawa ON K1A ON4

Canada
Your file Votre référence

ISBN: 978-0-494-81651-6

Our file Notre référence

ISBN: 978-0-494-81651-6
NOTICE:

The author has granted a nonexclusive license allowing Library and Archives Canada to reproduce, publish, archive, preserve, conserve, communicate to the public by telecommunication or on the Internet, loan, distribute and sell theses worldwide, for commercial or noncommercial purposes, in microform, paper, electronic and/or any other formats.

The author retains copyright ownership and moral rights in this thesis. Neither the thesis nor substantial extracts from it may be printed or otherwise reproduced without the author's permission.
AVIS:

L'auteur a accordé une licence non exclusive permettant à la Bibliothèque et Archives Canada de reproduire, publier, archiver, sauvegarder, conserver, transmettre au public par télécommunication ou par l'Internet, prêter, distribuer et vendre des thèses partout dans le monde, à des fins commerciales ou autres, sur support microforme, papier, électronique et/ou autres formats.

L'auteur conserve la propriété du droit d'auteur et des droits moraux qui protège cette thèse. Ni la thèse ni des extraits substantiels de celle-ci ne doivent être imprimés ou autrement reproduits sans son autorisation.
In compliance with the Canadian Privacy Act some supporting forms may have been removed from this thesis.

While these forms may be included in the document page count, their removal does not represent any loss of content from the thesis.
Conformément à la loi canadienne sur la protection de la vie privée, quelques formulaires secondaires ont été enlevés de cette thèse.

Bien que ces formulaires aient inclus dans la pagination, il n'y aura aucun contenu manquant. 


\begin{abstract}
This study examines the tactical, strategic, and psychological aspects of Canadian trench raiding within the context of military operations, from their beginnings in 1915 to the end of the war in late 1918. Trench raiding underwent three major evolutionary phases, transitioning from small, improvised affairs, to major undertakings that mirrored set-piece battles. Within this evolutionary process, trench raids served as the laboratory where the Canadians honed their tactical doctrine and experimented with new weapon systems. Trench raiding was fundamental to the development of combined arms tactics that emerged later in the war, culminating in the Hundred Days offensives, and was a key reason the Canadians earned a reputation as elite "shock troops."
\end{abstract}




\section{ACKNOWLEDGEMENTS}

This work could not have been completed if I had not had an enormous amount of help from key individuals. They have helped make this a much better history than it otherwise would have been. I am deeply indebted to my thesis supervisor, Dr. Tim Cook, who remained patient throughout the process. It was his comments, advice, and invaluable wisdom that inspired me to keep going despite setbacks and difficulties. He never seemed too busy to deal with my seemingly endless troubles, for which I can never thank him enough. I am also indebted to Joan White, the graduate secretary at Carleton University, who took in this bewildered and lost puppy and patiently explained administrative processes and the many other things that I did not comprehend about graduate work. Without her patience and guidance I would have not been able to finish this work in any coherent manner. Dr. Marc Tyrell and Dr. Jan Fedorowicz at Carleton provided me with ample encouragement and support, and were very generous with their class lectures by allowing me to share my material with their students. Dr. Chris Adam at Carleton was very kind in permitting me to lecture on the Great War in his classes. Chris Schultz provided me with an open mind to voice my frustrations and ideas to, and always encouraged me to push a little harder or challenged me to be a better writer. Thank you to the Enriched Support Program at Carleton University for giving me a second chance at a higher education, and also keeping me employed throughout my studies. I also wanted to thank the staff at the Library and Archives of Canada, and Carol Reid at the Canadian War Museum, who put up with my long research hours and demands for enormous amounts of material within a very condensed timeframe. My family and friends have been very supportive, and their constant encouragement gave me confidence to get this done. Most of all, I thank my new wife, Shawna. Her love and encouragement throughout the process was the reason I worked so hard to get it done. Her unwavering support during my long hours of research and writing is the very reason I was able to complete this work at all. Her love and smile was a guiding light when I encountered frustrations, setbacks, and lost confidence in my abilities. Without her I would be lost and without opportunity, or reason, to do what I love.

Thank you to all who helped,

Colin Garnett

Spring 2011 


\section{TABLE OF CONTENTS}

$\begin{array}{ll}\text { Abstract } & \text { ii }\end{array}$

Acknowledgements

Table of Contents $\quad$ iv

Abbreviations $\quad \mathrm{V}$

List of Maps $\quad$ vi

Introduction / Historiography

$\begin{array}{lr}\text { Chapter I: Early Raiding: Ypres late 1915-Somme } & 18\end{array}$

Chapter II: Organized/Mass Raiding: Post Somme-Vimy Ridge 58

Chapter III: Professional Raids: Post Vimy-Hundred Days 104

$\begin{array}{ll}\text { Conclusion } & 146\end{array}$

$\begin{array}{ll}\text { Bibliography } & 151\end{array}$ 


\section{ABBREVIATIONS}

$\begin{array}{ll}\text { BEF } & \text { British Expeditionary Force } \\ \text { Bde } & \text { Brigade } \\ \text { Btn } & \text { Battalion } \\ \text { CEF } & \text { Canadian Expeditionary Force } \\ \text { CMR } & \text { Battalion, Canadian Mounted Rifles } \\ \text { CWM } & \text { Canadian War Museum } \\ \text { Div } & \text { Division } \\ \text { HE } & \text { High Explosive } \\ \text { KIA } & \text { Killed in Action } \\ \text { LAC } & \text { Library and Archives Canada } \\ \text { LSH } & \text { Cavalry Battalion, Lord Strathcona's Horse } \\ \text { MIA } & \text { Missing in Action } \\ \text { NCO } & \text { Non-Commissioned Officer } \\ \text { OR } & \text { Other Ranks } \\ \text { PPCLI } & \text { Battalion, Princess Patricia's Canadian Light Infantry } \\ \text { POW } & \text { Prisoner of War } \\ \text { RCA } & \text { Royal Canadian Artillery } \\ \text { RCR } & \text { Battalion, Royal Canadian Regiment } \\ \text { RG9 } & \text { Record Group 9, Department of Militia and Defence } \\ \text { SAA } & \text { Small Arms Ammunition } \\ \text { TM } & \text { Trench Mortar } \\ \text { WD } & \text { War Diary } \\ \text { WIA } & \text { Wounded in Action } \\ \text { ZH } & \text { Zero Hour }\end{array}$




\section{LIST OF MAPS}

Intelligence Sketches of German Trenches, 30-31 January 1916

(LAC, WD, $28^{\text {th }}$ Battalion, 31 January 1916.) 


\section{Introduction / Historiography}

\section{Introduction}

The planners left nothing to chance. Everything had been accounted for, from the equipment, and chosen men, to the S.O.S. signal flares for the artillery and the code words for sentries in neighbouring battalions, just in case some stragglers after the attack entered friendly trench lines in a different battalion's sector. Yet in the end, despite all the preparation, planning, training, and battlefield experience, it sometimes came down to luck whether everything would work out. On the early morning of 27 November 1916, it seemed luck was with the infantry of the $31^{\text {st }}$ Battalion, Canadian Expeditionary Force. ${ }^{1}$ The 14 raiders, one sergeant, one corporal, and 12 privates, lay motionless in the dark. ${ }^{2}$ The ground was hard and frozen in front of Vimy Ridge, and the wait had been excruciating. But soon all hell was about to break loose on their small peaceful section of the Western Front, for when the signal came, these elite soldiers would storm the German trenches with grenade, bayonet, pistol, and club.

Surprise was on the raiders' side, and that was due to the thorough planning. In conjunction with the two assault teams of seven raiders each, who had their own defined role in the assault, covering parties were set up to watch the point of the attack, making sure that the Canadians had a clear path to the German trenches. ${ }^{3}$ Artillery was arranged to cover the assault with a box barrage that cut off the attack area and isolated those inside with a curtain of high explosive and shrapnel. ${ }^{4}$ Everything was timed down to the minute. That minute came at 0332 , when the artillery opened up right on time at zero hour, signalling to the raiders to spring up and

\footnotetext{
${ }^{1}$ Library and Archives Canada [LAC], War Diary [WD], $31^{\text {st }}$ Infantry Battalion, 27 November 1916. All LAC War Diaries, and other notes and appendices otherwise not with a Record Group [RG] or Manuscript Group [MG] number, were sourced from the archives' online digitized database from www.collectionscanada.ca.

${ }^{2}$ LAC, WD, $31^{\text {st }}$ Infantry Battalion, "Operation Order for Proposed Raid on November 27, 1916," 25 November 1916.

${ }^{3}$ LAC, WD, $31^{\text {st }}$ Infantry Battalion, "Special Report on raid on November 27, 1916," 27 November 1916.

${ }^{4}$ Ibid.
} 
storm the German trenches. Each assault party crashed into the enemy lines, one moving left and the other going right. Men were stationed at the point of entry to cover the withdrawal and to facilitate evacuation of any prisoners who might be captured. Smashing their way down the German lines, the left party with a Non-Commissioned Officer (NCO) as its commander advanced for 40 yards, yet found nothing but untended muddy trenches that had been battered by Allied artillery to greet them - the Germans were nowhere to be seen.

The right party was luckier, encountering a post which contained five Germans. In the ensuing violent clash, two lay dead and two got away carrying their wounded comrade. Since one of the objectives of the operation was to obtain identification of the German units in this area, the raiders attempted to pull the bodies back to their own lines. ${ }^{5}$ This was at the best of times a difficult procedure, and due to complications in the thickness of German wire and other circumstances at the time, this initiative was abandoned. With their time up after only a few minutes, the $\mathrm{NCO}$ in charge gave the signal to withdraw before enemy reinforcements regrouped and overwhelmed his diminutive force. The Canadians got back to their own lines without suffering any casualties, but identifications were not obtained. ${ }^{6}$ Yet, despite this setback, their operation had inflicted losses on the enemy and they had survived to do it all again on some future night.

This operation was one of many raids that Canadian fighting formations would carry out throughout the war. They would attack seemingly out of nowhere with suddenness and ruthlessness, and then disappear just as fast as they came - leaving behind enemies stabbed in their sleep, clubbed to death, bombed while trapped in dugouts, or shot down as they ran in dazed confusion. These chosen men were members of some of the most feared assault units on

\footnotetext{
${ }^{5}$ Ibid.
}

${ }^{6}$ Ibid. 
the Western Front. They were meticulous. They were cold in execution. They were organized. They were armed to the teeth. They were trench raiders.

The Great War, when conjured up in the imagination, reveals images of titanic battles where a cacophony of explosions erupted in geysers of mud, and the chatter of machine guns awaited the "poor bloody infantry" who marched to the slaughter. Hundreds of thousands of men were killed, fragile human lives thrown against the mechanical meat-grinder of modern military weaponry, for the gain of what seemed like a few feet of battlefield territory. Yet in between theses titanic but infrequent battles, the Western Front was still active, and very dangerous. This activity took the form of patrols and artillery duels, but it also involved deadly combat operations called trench raids.

A trench raid was an attack on an opposite trench system or fortification where the soldiers went in with specific objectives, usually the goal of destroying enemy supplies, morale, or personnel, and then withdrawing before the bewildered enemy could mount an effective defence. These small-scale attacks had significant battlefield implications. It was during trench raids that these Canadian infantrymen helped to forge their reputation as elite shock troops, and these raids provided the individuals and formations with opportunities to improve planning, organization, and fighting skills that paid dividends in the large set-piece battles to follow during the course of the war.

The battlefield on the Western Front was unlike anything the Canadian soldiers had seen before. The creation of this unique battlefield situation was the result of a combination of mechanization, advances in weaponry technology, and strategic misunderstanding from the 
generals, many of whom believed in a "cult of the offensive." This attack-centered approach emphasized the primacy of the assault as the key to victory on the battlefield, as exemplified in previous conflicts such as the Franco-Prussian War and the Russo-Japanese War. Yet the strategy of massed infantry attack was ill-matched against the destructive power of machine guns and quick-firing artillery. The result of antiquated attack tactics and improved defensive weaponry was slaughter. ${ }^{8}$

After the killing battles of 1914, warfare devolved from familiar field warfare to that of positional or siege warfare, with continuous underground trench fortifications that stretched from the Swiss border all the way to the English Channel. ${ }^{9}$ These trench lines on the Western Front created a unique and deadly battlefield environment, and strategy and tactics had to adapt to meet these new challenges. In between these two trench systems existed a space known as No Man's Land, a buffer zone of sorts, but one that could never be captured. When it was incorporated into one's lines after a successful operation or attack it always re-manifested, as the two sides required the zone to ensure there was not continuous warfare. ${ }^{10}$ Private Bert Cooke of the $75^{\text {th }}$ Battalion remembered that desolate wasteland as "that space between our trenches and the enemy trenches. To venture into 'No Man's Land,' sudden death is your prime thought; the 'Land' is littered with crater holes from the shelling and is full of barbed wire entanglement. Sometimes a rat would scamper along the top of the trenches. Even the rat got shot!"11

\footnotetext{
${ }^{7}$ Archer Jones, The Art of War in the Western World. (Chicago: University of Illinois Press, 2001), 440-441. For further discussion of the technological aspects of the Great War and the tactical stalemate, see Eugene Emme, "Technical Change and Western Military Thought: 1914-1945" Military Affairs, Vol. 24, No.1 (Spring, 1960), 8-9.

${ }^{8}$ John Keegan, A History of Warfare. (Toronto: Vintage Canada, 1993), 361-362. For a more thorough discussion of the foreshadowing of trench warfare by the Franco-Prussian War and Russo-Japanese War, see Jones, 439-440.

${ }^{9}$ John Keegan, The First World War. (London: Random House Ltd., 2001), 116-119.

${ }^{10}$ Jack Granetstein and Desmond Morton, Marching to Armageddon: Canadians and the Great War 1914-1918. (Toronto: Key Porter Books, 1989), 37-38.

${ }^{11}$ Bert Cooke, We're Not Dead Yet: The First World War Diary of Bert Cooke. Milly Walsh and John Callan (ed). (St. Catherines: Vanwell Pub., 2005), 73.
} 
As the war progressed and offensive operations floundered with heavy costs in lives, the Allied high command's focus shifted from searching for the clear breakthrough through the enemy trench, to "bite and hold" operations, which involved taking ground from the enemy and defending it against counterattack. This happened in mid-1917, after the "big push" at the Battle of the Somme in the summer and fall of 1916 failed to achieve that much sought after breakthrough. ${ }^{12}$ Hard lessons were learned, and success was achieved, but the newer style of offensive battle was no less costly. Bite and hold operations proved immensely difficult to accomplish due to the immense planning required and seemingly little strategic gains they accrued. The power of the defensive, with trenches in depth and protected by barbed wire, machine guns, and shellfire, still made offensive operations costly. Traversing No Man's Land was always done against a storm of enemy fire and once crossed, the then depleted infantry were left to dig in and hold the newly captured trenches against inevitable German counterattacks. ${ }^{13}$ These big battles were so costly that only a few could be carried off each year.

Trench raids were, in theory, offensive operations with destructive aims but required little investment or consolidating newly-acquired territory. To put it simply, instead of "bite and hold" operations, these trench raids were "butcher and bolt." The trench raid achieved several important goals for the Canadian troops. First, it provided a way for the troops to strike back at an otherwise unseen and unassailable enemy. By providing a way to strike back, raiding had a large part to play in the psychology of warfare, particularly in building or sustaining morale. With the fighting being so costly in lives, soldiers had to adapt on a social, cultural, and psychological level in order to cope.

\footnotetext{
12 Jones, 462-463.

${ }^{13}$ Keegan, First World War, 180-181.
} 
Tactics needed to change to meet the realities of trench warfare. Raiding was one such adaptation. As a part of this process, trench raiding became an integral part of Canadian infantry combat doctrine, and served as a major source of garnering experience and technological experimentation. This would later benefit the Canadians when they took part in the large, setpiece battles such as Vimy Ridge or Amiens. Over the course of the Great War, Canadian soldiers planned and executed hundreds of raids of varying sizes along the Western Front, sometimes sending out a raiding party every night before a big offensive, as was the case before Vimy Ridge in April 1917. These raids had a large part to play in the British strategy of attritional warfare, which was the constant wearing down of the German forces in materiel and morale, which would eventually lead to victory on the Western Front.

\section{Chapter Roadmap}

The objective of this thesis is to investigate Canadian trench raids throughout the war, and analyse their impact on the battlefield experience of the Canadian soldier. This will be accomplished by chronologically investigating key points in the development of trench raids on the Western Front, from their origins in 1915 up to and including the Hundred Days offensives. This analysis will be augmented with relevant discussion on important aspects of trench raiding that relate to that particular raiding "phase." Canadian trench raiding went through three phases of development, separated by two of the most significant large set-piece battles of the war: the Battle of the Somme in 1916 and the Battle of Vimy Ridge in $1917 .{ }^{14}$

\footnotetext{
${ }^{14}$ See F.P. Todd, "The Knife and Club in Trench Warfare, 1914-1918," The Journal of the American Military History Foundation, Vol. 2, No. 3 (Autumn, 1938), 140-141. Todd offers an explanation of the two major phases of trench raiding. He divides trench raids into two phases that are separated by the end of the Somme: "stealth" and "raid in force." This division is largely correct, but the second phase is more nuanced than that in terms of tactical development and strategic utility. This is why this thesis uses the Battle of Vimy Ridge to separate the "raids in force" into two groups: "semi professional" and "professional."
} 
The first chapter discusses the genesis of trench raids in mid-1915 and documents their development to the eve of the Battle of the Somme in the summer of 1916. The background of raiding within the British Expeditionary Force (BEF) will be analysed, including notions of elitism and ethos within the Canadian forces during this escalating period of trench warfare. This chapter will also attempt to investigate the complex front line issues of live and let live and how raiding served to support or challenge this system of battlefield truces. Special emphasis will be afforded to the system of small-arms and close-combat weaponry that made up the majority of the raiders' arsenal, and how these weapons played into the larger tactical and strategic picture of trench warfare.

In early 1916 , raiding became a more systematic operation, with the initiative to raid coming from the upper echelons of command as opposed to being of local initiative from a company or battalion commander. Of special concern here are the reasons why the British high command, including the newly-appointed General Sir Douglas Haig, standardized raiding throughout the BEF. This command decision had far-reaching effects within the units fighting in the trenches, driving them to carry out more numerous raids and sometimes with insufficient time to plan for them. The chapter will conclude with an examination of how trench raids had evolved and grown in operational importance over the course of the summer of 1916 .

The second chapter examines how trench raiding underwent a dramatic shift in late 1916 and early 1917. Beginning with an analysis of the hard lessons of the Somme, this chapter explores the second era of Canadian trench raids, where raids became organized and systematized. During this era, raids were increasingly launched with the goal of gathering intelligence related to the enemy. A key component of trench raiding, the capturing German prisoners, will also be discussed in detail, for capturing prisoners while on a raid behind enemy 
lines introduced a great many difficulties and challenges to the soldiers carrying out trench raids. This era of raiding revealed the continual tactical learning curve that the Allied forces underwent as they attempted to adjust to trench warfare. This learning process was not without its hard lessons, as the number of costly, aborted, and failed raids indicates during this difficult era. Infantry assault planning evolved too, with the creation of separate specialist "parties" that had specific objectives and functions within the raid, such as assault teams, engineers, covering teams, and scouts. Trench raids allowed for experimentation in combined-arms warfare without the expense or risk of a large-scale offensive. This is especially true with the development of the close relationships between those at the sharp end and the support provided by trench mortars, artillery, Stokes guns, machine guns, gas, signals, and other support weapons within the BEF. But raiding was not always a success story. When they went wrong, they left trained soldiers dead and wounded, and the survivors with lowered morale. Discussing failed raids is of vital importance in understanding the psychological impact trench raids had on the Canadian soldier.

The third chapter explores the final era of Canadian trench raids: the raids following the Battle of Vimy Ridge in April 1917 through to the Hundred Days offensives that took place in the late summer 1918. These raids were more professional, with raiders building on the lessons of 1915,1916 , and especially 1917 . Yet was raiding beneficial to the tactical situation? Did they contribute to General Haig's strategy of attrition that he subscribed to since early 1916 ? This chapter will attempt to investigate this issue in relation to the raids carried out, their objectives, achievements, and the costs incurred.

As raids developed, so did the raiders' arsenal of weaponry. This development in technological experimentation will be discussed in this chapter with reference to the use of rifle 
grenades and other support weapons. These weapons allowed the raiders to be self-sufficient assault units utilizing "fire and movement" tactics with the capability of independently attacking German defences. The chapter will conclude with a discussion of the final evolution of trench raids during the Hundred Days campaign. This period featured sustained open warfare, and tactics needed to be changed accordingly. Trench raids evolved during this time, coming full circle back to the aggressive patrols that they originated from in mid-1915. Yet, as will be seen, these "old" tactics incorporated all of the lessons that raiding revealed to the Canadians over the past three years of trench warfare. Raids evolved to serve the battlefield circumstance, and taught lessons, although sometimes at prohibitive cost.

This thesis will argue that raiding, or minor operations as they were sometimes labelled, was an integral part of infantry warfare and played an important role in shaping Canadian attack doctrine, development and usage of weaponry, experimentation of new technology and its integration into emerging tactical systems, and served as a major factor in influencing the battlefield morale of the Canadian infantrymen. There was certainly nothing "minor" about these dangerous operations.

\section{Historiography}

Considering that raiding had such a wide-spread impact on the Canadian infantry combat experience, it is surprising to discover the lack of sustained historical investigation into this topic. The works that cover the Great War are numerous and wide-ranging in emphasis and historiographic worth, but a few deserve specific mention in that they have had an impact on my approach to this topic. Any investigation into the historiography of Canadian military history would be incomplete without first consulting Tim Cook's Clio's Warriors: Canadian Historians and the Writing of the Two World Wars. Cook elucidates the many critical developments of 
Canadian military history writing, tracking the evolution from early historians such as C.P.

Stacey, who practiced the traditional model of "top down" military history, to modern historians such as Jonathan Vance and Desmond Morton, whose work is informed by newer historiographic trends such as social and cultural history. Cook also uncovers the inherent difficulty of military history writing within the discipline as a whole, and the marginalization of military history by mainstream academics. ${ }^{15}$

The subject of trench raiding has been covered episodically by Canadian historians. Tim Cook's At the Sharp End and Shock Troops, a two volume documentation of Canadian participation on the Western Front from 1914 to 1918, discusses raiding in two of its chapters. The raiding-centric chapter from At the Sharp End, titled "Winning Control of No Man's Land: Canadian Raiding, 1915," discusses the background and emergence of organized raids in late 1915 , with a specific case study of the $7^{\text {th }}$ Battalion raid on Petit Douve on November $15,1915 .^{16}$ The second chapter, called "Raiding: The Laboratory of Battle - Raiding January-April 1917" focuses on the integration and experimentation of technology and tactical doctrine within raiding after it was infused into regular offensive attack strategic doctrine in 1916. He also discusses not only the advantages of the many raids that occurred during this time period, but the disadvantages as well, as is highlighted in his case study of the "March 1 Gas Raid" prior to the Battle of Vimy Ridge. ${ }^{17}$ These two chapters discuss many important aspects of raiding, but they are far too brief in order to really investigate the complex issues trench raids introduce into the historiography of the Great War.

\footnotetext{
${ }^{15}$ Tim Cook, Clio's Warriors: Canadian Historians and the Writing of the World Wars. (Vancouver: UBC Press, 2006), 247-249.

${ }^{16}$ Tim Cook, At the Sharp End: Canadians Fighting the Great War 1914-1916. (Toronto: Penguin, 2007), 291.

${ }^{17}$ Tim Cook, Shock Troops: Canadians Fighting the Great War 1916-1918. (Toronto: Penguin, 2008), 67.
} 
J.L. Granatstein and Desmond Morton, two esteemed Canadian military historians, collaborated on the popular Marching to Armageddon: Canadians and the Great War 19141918. There is only a cursory paragraph on trench raiding. ${ }^{18}$ Desmond Morton also wrote an excellent account of the Canadian soldier in the Great War, When Your Number's Up. It offered a vivid portrait of the experiences of Canadians during the war, yet again trench raiding only warranted a mere paragraph - lumped in with a discussion of daily trench life and attrition on the battlefield.

To provide balance to my research, the German perspective of fighting on the Western Front needs to be understood. One of the most definitive portraits of the German war experience is Ernst Junger's Storm of Steel, documenting his days as a "storm trooper" on the Western Front during 1917-1918. He describes in great detail the German raids that he took part in, including the psychological effect they had on both him and those he was attacking. Most interestingly, he also mentions defending against British raids. ${ }^{19}$ These raids could well have had Canadians taking part, as they were part of the British Expeditionary Force during the war. Another noteworthy work on the German viewpoint of trench warfare is Bruce Gudmundsson's Stormtroop Tactics: Innovation in the German Army: 1914-1918. He analyses the tactical and strategic aspects of German assault doctrine as it developed throughout the war, and provides excellent insight into both the stiff opposition Canadian raiders were facing when they went out on a raid, but also the tense experiences they had whilst on the receiving end of a German assault. $^{20}$

\footnotetext{
${ }^{18}$ Jack Granetstein and Desmond Morton, Marching to Armageddon, 38.

${ }^{19}$ Ernst Junger, Storm of Steel. (London: Penguin, 1961), 71.

${ }^{20}$ Bruce Gudmundsson, Stormtroop Tactics: Innovation in the German Army: 1914-1918. (New York: Praeger Publishers, 1989), 81.
} 
Lieutenant-Colonel D.E. Macintyre's Canada at Vimy is an engaging and illuminative work by a Canadian front line soldier. ${ }^{21}$ Although primarily a discussion of the pivotal battle on 9 April 1917, this book contains many references to trench raids and operations planning. D.E. Macintyre was scouting officer of the $28^{\text {th }}$ Battalion, and organized one of the early major raids on 30-31 January 1916. Macintyre's book discusses trench raids, both their benefits and their drawbacks. The dichotomy between positive and negative aspects of performing trench raids has become one of the dominant discussions surrounding trench raiding: was it inherently good or was it ultimately a detriment to Canadian battlefield morale, fighting efficiency, and skill development on the Western Front?

One crucial area of Great War historiography where trench raiding is most applicable is discussions of operational and technological nature. Trench raiding was a combat tactic, a form of attack where little by way of resources or men was invested for slow, incremental gains. The tactical and strategic implications of trench raiding have not gone unnoticed by Great War historians, although unfortunately they tend to focus on either tactics and attack doctrine, or technology and weaponry. The psychological impacts, issues of command and control, and leadership are all left out. Trench raiding involved complex organization, planning, and extreme combat skill in order to carry out properly. In analysing combat tactics in the Great War, specifically the evolution of attack doctrine within the BEF, Paddy Griffith's Battle Tactics of the Western Front: The British Army's Art of Attack 1916-18 offers a controversial response to the dominant conclusions concerning Allied offensive tactics during the Great War. He argued that the evolution of BEF offensive tactics was a complex process, and that the Allies had not merely stumbled along from one military catastrophe to another with little thought to tactical doctrine, weapon systems, or other concerns for modern combat operations. According to

\footnotetext{
${ }^{21}$ Donald Macintyre, Canada at Vimy. (Toronto: Peter Martin Associates, Ltd., 1967), 71-72.
} 
Griffith, the Allied soldiers were not stereotypically "lions led by donkeys," but rather a part of a learning military machine that was adapting to its given environment and developing tactics and strategies to overcome the obstacles presented them. ${ }^{22}$

This new perspective on the old stereotypical point of view of the tactical development of attack doctrine within the Great War provides a useful backdrop to inform my research into Canadian trench raiding. Raids are a perfect example of Griffith's central thesis: the Allies were adapting and even overcoming the immense obstacles presented to them in terms of weaponry, technology, tactics, and command and control. The perceived impregnable combination of machine gun, artillery, and fortification presented by the defending German armies could be conquered by a matter of developing the right weapon systems and tactics to deal with them most effectively, with trench raiding playing an integral part in this tactical evolution. The only downfall of Griffith's work is that he does not concentrate enough on minor operations, such as patrolling and raiding. He does go into length in mentioning their tactical utility, but does little else in attempting to explain how they played a part in the overall scheme of the Allied soldier's combat experience. Even though this book concentrates largely on the British experience, there are many lessons to be derived from it.

Similar to Griffith's work, Bill Rawling's Surviving Trench Warfare: Technology and the Canadian Corps examines technology, tactics, and weapon systems. ${ }^{23}$ Weaponry and technology are amply covered, but Rawling downplays the human elements in raiding. Like Griffith's book, Rawling concentrates on the machines and tools, but not the men. Gauging the points of view of the common soldier, and how they felt about raiding, is vital to assessing the overall effect trench

\footnotetext{
${ }^{22}$ Paddy Griffith, Battle Tactics of the Western Front. London: (Yale University Press, 1994), 5.

${ }^{23}$ Bill Rawling, Surviving Trench Warfare. (Toronto: University of Toronto Press, 1992), 48.
} 
raids had on the Canadian war effort, not only in terms of tactical and technological evolution but also the will to fight and unit morale.

Other authors have also investigated technology and tactics during the Great War, and these works provided further foundation from which I developed my research. E.M. Emme's article "Technical Change and Western Military Thought: 1914-1945" from the Spring 1960 issue of Military Affairs, discusses technological evolution from a command and weaponry perspective. He is primarily concerned with large weapons systems, such as the tank, aircraft, and submarines, but he does provide compelling discussion of the issues surrounding the technological and tactical evolution of the machine gun and artillery during the Great War. Historian Robert Foley's article, "What's in a Name: The Development of Strategies of Attrition on the Western Front 1914-18," highlights the concept of attritional warfare within the German and Allied high commands. His conclusion, that attritional warfare was a reaction to battlefield circumstances, provides a good grounding for establishing the strategic importance of Canadian trench raiding.

A discussion of trench raiding must include those who took part in these deadly operations. Trench raiding was a tactic, a large component of the overall strategy of attrition, and an extremely potent expression of violence. Trench raiding had a severe effect on interbelligerent relations and reciprocation of notions of aggression. Yet many soldiers sought to avoid perpetrating the cycle of violence, and this was known informally as live and let live. ${ }^{24}$ Tony Ashworth's Trench Warfare: The Live and Let Live System is the definitive book on this aspect of trench warfare, and its findings have great implications for trench raiding. Published in 1980, it introduced new and controversial conclusions about the soldiers and their willingness to

\footnotetext{
${ }^{24}$ Tony Ashworth, Trench Warfare: The Live and Let Live System. (London: Pan Macmillan Ltd., 1980), 19.
} 
kill the enemy on the Western Front. His research found that many units within the BEF subscribed to live and let live, and in many forms it existed throughout the duration of the war. Ashworth devotes significant attention to trench raiding, as it was a direct challenge to the ethos of live and let live. According to Ashworth's findings, trench raiding was initially an expression of elitism within units of the BEF, which included the Canadians. However, after the systematization of raiding in mid-1916, it became a high command strategy to eliminate live and let live from the battlefield, and it was recognized that raiding was a source of instability to the socially-negotiated unofficial battlefield truces that constituted live and let live between the belligerent units. ${ }^{25}$ This book is crucial in assessing the varied effects and utilities of Canadian trench raiding.

Trench raiding served as a counter-force to the above mentioned live and let live paradigm of trench combat. Tim Cook's "The Politics of Surrender: Canadian Soldiers and the Killing of Prisoners in the Great War" from the The Journal of Military History's July 2006 issue discusses the act of surrender on the Western Front, and when it was or was not accepted. Cook's research shows how difficult it was to actually take prisoners, which was a frequent objective of trench raids. This article provided a framework to investigate the dark aspect of trench raiding, especially with reference to how murdering prisoners while on a raid affected the executioners, their resulting fighting efficiency, and mental state.

Alexander Watson's Enduring the Great War is an innovative look at how British and German troops coped with the stresses of combat, and whether those coping mechanisms helped to improve upon fighting efficiency, morale, offensive spirit, and overall combat effectiveness. ${ }^{26}$ This book does a great deal to further flesh out the psychological aspects of trench combat that

\footnotetext{
${ }^{25}$ Ashworth, 177.

${ }^{26}$ Andrew Watson, Enduring the Great War. (New York: Cambridge University Press, 2008), 19.
} 
the Canadian raiders faced on a daily basis, and forms an excellent basis upon which to study the psychological impact raids had on Canadian soldiers. This investigation into the real human aspect of trench warfare, pioneered by the likes of John Keegan and Tony Ashworth, is at the very heart of my research. ${ }^{27}$

It is important to understand that not all raids went well. Many in fact went disastrously wrong and resulted in appalling losses and devastated mental states to those who experienced the terror and slaughter of comrades. Tim Cook's "A Proper Slaughter: The March 1917 Gas Raid at Vimy" analyses this catastrophic raid, where gas was tragically experimented with instead of artillery as the support for the raiders' attack. ${ }^{28}$ This article provides a case study to explore issues of live and let live, command and control, and the psychological effects that trench raids had on the Canadians soldiers who participated in them. Other articles by Andrew Godefroy and Ken Reynolds provide case studies of raids that fared batter. Godefroy's article discusses the Calonne Trench Raid on January 17, 1917, and brings to light details of command, tactical specialization, and organization and planning. ${ }^{29}$ Reynolds" "Under the Cover of Darkness: The Canadian Trench raid of 8-9 June 1917" is another case study that also focuses on the operational parameters of the raid. ${ }^{30}$ Both of these raids are excellent case studies for elucidating the tactical and technological learning curve that Canadian raiders underwent in the final two eras of raiding.

The popular memory of the Canadian involvement in the Great War revolves around the large-scale set-piece battles at Ypres, the Somme, Vimy Ridge, Hill 70, Passchendaele, and the

\footnotetext{
${ }^{27}$ See John Kegan, Face of Battle A Study of Agincourt, Waterloo, and the Somme (London: Pimlico, 2004). This work is an example of one of the first 'bottom-up' approaches to military history, where the experience of the common soldier was the focus of discussion.

${ }^{28}$ Tim Cook "A Proper Slaughter: The March 1917 Gas Raid at Vimy," Canadian Milltary History, Vol. 8, No. 2 (1999), 8.

${ }_{29}$ Andrew Godefroy, "A Lesson in Success: The Calonne Trench Raid, 17 January 1917," Canadian Military History, Vol. 8, No. 2 (1999): 25-34.

${ }^{30}$ Ken Reynolds, "Under the Cover of Darkness: The Canadian Trench Raid of 8-9 June 1917" In Fortune Favours the Brave Tales of Courage and Tenactty in Canadian Military History, ed Bernd Horn. (Toronto: Dundurn Press, 2009), 143.
} 
Hundred Days. Yet the time in between those big battles, where remorseless artillery bombardments shattered the soldiers' boredom and stagnant repetition in the trenches, has been inadequately studied. Trench raiding shaped and impacted the period in between the battles, and a study of these minor operations provides greater insight into the Canadian wartime experience. 
CHAPTER I: Early Raiding: Late 1915 to The Battle of the Somme

\section{Fighting for No Man's Land}

Trench raids are an example of an improvised military tactic being adapted to an unfamiliar combat situation. Raids began as an informal reaction to a static battlefield, and had their origins in the combat patrol. Patrols served primarily as a method of reconnaissance and information gathering in No Man's Land, and usually involved only a few scouts reconnoitring the enemy positions. These night-time patrols became common to the battlefield after the open warfare phase degenerated into trench warfare, and within a few months enterprising soldiers had begun to carry out "offensive" or "aggressive" patrols. Instead of avoiding contact, like the reconnaissance patrols, these aggressive patrols sought to attack enemy patrols, working parties, or outposts. ${ }^{31}$ Lieutenant James H. Lovett described one such patrol on 24 December 1915: All at once the Germans challenged us, and two rifles were fired almost into my face...the party, in spite of having no cover, gave it to them right and left. Bombs, rifles, everything went, a little war all to ourselves. We made them get away from the hedge, and a machine-gun opened up on us, and we had to get back into a nearby ditch and from there into the trench. I was very glad to get the party back safely. $^{32}$

The dangerous nature of these minor operations is illustrated in the above account. ${ }^{33}$ Yet it was these patrols, though costly on occasion, which kept the tactical initiative on the battlefield in the Canadians' favour. By aggressively patrolling No Man's Land, the Canadians made it a point of

\footnotetext{
${ }^{31} \mathrm{LAC}, \mathrm{WD}, 28^{\text {th }}$ Infantry Battalion, 3 June 1918.

${ }^{32}$ Canadian Bank of Commerce, Letters from the Front, Being a Record of the Part Played by Officers of the Bank in the Great War, 1914-1919, Volume 1. [Hereafter referred to as LFTF] (Canadian Bank of Commerce Press, 1920), 78.

${ }^{33}$ For further discussion on the perceived danger of patrols, see Leo van Bergen, Before My Helpless Sight: Suffering, Dying, and Military Medicine on the Western Front, 1914-1918. (Aldershot: Ashgate, 2009), 203-204.
} 
pride to keep the enemy in his own trenches, behind barbed wire, and unwilling to push the attack into Canadian lines.

Patrols served to give the more aggressive side "ownership" of No Man's Land, which entailed certain benefits to the owner of this dangerous and fluid battle-space. First of all, dominance of this space - by forcing the enemy to stay in his trench - meant that scouting of the enemy's line was much easier, with patrollers generally unbothered by hostile enemy patrols, which could disrupt reconnaissance missions and potentially kill or capture valuable scouts. Second, dominance of No Man's Land meant that the Germans were denied the same opportunities at reconnoitring the Canadian line. ${ }^{34}$ "A German prisoner taken recently said he was the first man in his regiment who had ever gone on a patrol," wrote Lieutenant-Colonel D.E. Macintyre of the $28^{\text {th }}$ Battalion in his diary, "and his officers and friends had all shaken hands with him and said good-bye before he left." ${ }^{\prime 35}$ The aggressive Canadian patrols, which led to the ownership of No Man's Land, were an essential step in the preparation of larger raids on the enemy's trenches. ${ }^{36}$ Sergeant Fred Bagnall of the $14^{\text {th }}$ Battalion described the usefulness of the first patrols as the means of creating a forward defence: "they were very satisfying to us because it provided a means by which we could avoid surprise. ${ }^{37}$ The Germans, by abandoning their observation posts and by neglecting to seriously contest the Canadian and British dominance of No-Man's Land, revealed one of the latent functions of raiding: the destruction of enemy morale. A veteran German soldier summed up this sentiment: "I hope the Canadians are not opposite you... On the darkest nights they jump suddenly into our trenches, causing great consternation

\footnotetext{
${ }^{34}$ Rawling, Surviving, 48.

${ }^{35}$ LAC, MG30 E241, D.E. Macintyre papers, 22 March 1916, 136.

${ }^{36}$ Rawling, Surviving, 47.

${ }^{37}$ Fred Bagnall, Not Mentioned in Dispatches: The Memoir of Sgt. Fred Bagnall, 14 ${ }^{\text {th }}$ Battalion CEF: 1914-1917. (Ottawa: CEF Books, 2005) 77.
} 
and before cries of help can be answered disappear again into the darkness. ${ }^{\prime 38}$ Private Harold Peat of the $3^{\text {rd }}$ Battalion expanded upon the origins of this Canadian reputation as fierce warriors: "The Indian regiments...were the most feared by the Hun..To-day the Canadians in France are known by the enemy as the 'white Ghurkhas,' and this, to us, is one of the highest compliments. The Ghurkhas are considered bravest of the brave. Shall we not be proud to share a title such as this?"39 Assuming that the accounts above can be extrapolated to reflect a general attitude towards the Canadians, the tactics of aggressive patrols and raiding were effective at driving fear and uncertainty into the German infantrymen.${ }^{40}$ Raids and aggressive patrols were primarily tactics of de-stabilization - causing chaos and sowing uncertainty into the enemy.

\section{Raids: A Matter of Language}

The above discussion of minor operations introduces the question of what kind of operation must have been undertaken for it to be termed a "raid" as opposed to an "aggressive patrol?" As these official records, war diaries, and battalion histories indicate, there is a great amount of confusion and ambiguity surrounding the classification of minor operations, with certain kinds of operations labelled many different names. ${ }^{41}$ This inconsistency in classification, especially in the first era of raiding from 1915 to late 1916, is probably due to these new and developing tactics having few doctrinal standards or definitions, especially for the officers who were forced to write up the reports of operations. ${ }^{42}$

These trench soldiers had numerous names for seemingly very similar offensive operations. These included: show, enterprise, minor operation, special operation, bombing raid,

\footnotetext{
${ }^{38}$ Cook, At the Sharp End, 300.

${ }^{39}$ Harold Peat, Private Peat. (New York: Grosset and Dunlap Pub., 1917), 114-115.

${ }^{40}$ For further discussion about the Canadian reputation in the eyes of the Germans, see Cook, At the Sharp End, 300.

${ }^{41}$ For an example of mixed nomenclature within the description of raids, see Ralph Hodder-Williams, Princess Patricia's Canadian Light Infantry, 1914-1919. (Edmonton: Executive Committee PPCLI, 1968), 207-208. The author describes the action on 28 May 1917 as a patrol, yet the operation is clearly a minor raid.

${ }^{42}$ Mike Senior, "Raids and Patrols: What's the Difference?," The Western Front Association: Stand To!, No.89, (August/September 2010), 9-11.
} 
minor raid, bombing patrol, stealth raid, silent raid, dummy raid, or Chinese attack. ${ }^{43}$ Taking these many terms into consideration, historians generally categorize raids and patrols along the following general lines. ${ }^{44}$ Patrols were operations featuring small parties, chiefly scouts and intelligence officers, whose primary goal was reconnaissance and information gathering, not overt offensive action. They generally did not engage enemy positions unless provoked, for their role was information gathering in No Man's Land for a future offensive operation - such as a raid. A fighting patrol or aggressive patrol was similar to that of an intelligence-gathering patrol except these small parties openly confronted enemy patrols and working parties in No Man's Land, and also sought to attack enemy sentry posts, saps, or other vulnerable targets of opportunity in the hope of securing a prisoner or some useful intelligence. Sometimes these fighting patrols would enter enemy trenches and thus become a kind of impromptu raid, but their primary objective was that of reconnaissance, not combat, although the line between these fighting patrols and actual raids was often blurred.

An attack simply termed as a "raid" might contain some of the above elements, but usually also entailed a minor offensive operation, numbering from a handful of men to over a thousand, along with the added complexity of support from other fighting arms including artillery, machine guns, and trench mortars. The objectives of raids were multi-faceted, but usually centered around destroying emplacements, killing the enemy, and securing prisoners or intelligence. A bombing attack or minor raid was essentially the same thing, with a smaller number of raiders who attacked a specific section of trench or strongpoint, with the intention of doing damage and killing enemies, along with capturing prisoners. Stealth or silent raids were

\footnotetext{
${ }^{43}$ Ibid, 10.

${ }^{44}$ Senior, 9.
} 
another modification to the traditional raid, and they usually dispensed with artillery or mortar support at the moment of attack, to preserve the element of surprise. ${ }^{45}$

To sum up, the difference between the patrol and the raid is the area of operations: a patrol was concerned with No Man's Land, and a raid was usually tasked with physically entering enemy trenches. These are the definitions that this thesis will use in discussing raids. Although some references to trench raids might be arguably one form of minor operations or another, the important thing to consider is that the men who carried out these operations starting in 1915 were not overly concerned about nomenclature. They faced the danger of No Man's Land and the enemy.

\section{Shelley Farm Raid, 27-28 February 1915}

The first raids were so embryonic and $a d$ hoc in nature that they could not really be termed proper trench raids. These early operations were closer to fighting patrols that ended up assaulting German trenches. The earliest minor operations were carried out by the $1^{\text {st }}$ and $2^{\text {nd }}$ Gerwhal Rifles, an Indian unit, on 10-11 November 1914, when they snuck into German trenches in a "hit and run" attack. ${ }^{46}$ The elite $2^{\text {nd }}$ Royal Welch Fusiliers, whose aggressive officers trained the Canadians in close combat tactics when they arrived in France in February 1915, performed many fighting patrols against the German lines throughout the early period of 1915. ${ }^{47}$ Raiding gave these elite formations a sense of agency in an otherwise mechanical and macro-scale war. Raiders, with blackened faces, balaclavas on their heads, and sporting a wide array of deadly weaponry, were exerting their will on the enemy and creating a clique of elites

\footnotetext{
${ }^{45}$ For a complete chart of definitions explaining the differences between these minor operations and the reasoning behind my uses of these classifications, see Senior, 10.

${ }^{46}$ Rawling, Surviving, 47.

${ }^{47}$ Ibid.
} 
within their fighting forces. ${ }^{48}$ Early raids were the result of local initiative of the junior officers. These unofficial trench operations were often planned and carried out without the prodding or orders of the high command and, in addition to exerting control over No Man's Land, as an attempt at forging a reputation. ${ }^{49}$ Medals, status and honour, extra leave, rum rations, and exemption from menial tasks were all benefits that went to patrollers and raiders if they undertook this dangerous work. ${ }^{50}$ Trench raiders were skilled killers and thus could be saved from the mundane tasks associated with trench work - their contribution to the unit was slaying the enemy.

Early raids also served as a way to strike back against an otherwise unassailable enemy who used their long-range artillery to devastating effect. Private Bert Cooke of the $75^{\text {th }}$ Battalion remembered these artillery attacks: "[sic] Suddenly, you hear the whistling of a bomb; seconds later an explosion, I then see the body parts...scattered about. One men had his head blown off...It is awful seeing such horror happening all the time." 51 Sergeant Charles Savage from the $5^{\text {th }}$ C.M.R. echoed that feeling of helplessness as the shells rained down on his unit: "It was a hopelessly rotten show. Thirty-two out of thirty-seven men were killed or wounded without ever having a chance to hit back in any way." ${ }^{, 52}$ Raiding provided a means of striking back against the enemy, exacting revenge for the horrible suffering caused by enemy artillery that killed and maimed more men than any other weapon of the war.

One of the first Canadian raids was carried out by the Princess Patricia's Canadian Light Infantry (PPCLI), a "reconnaissance in force" against Shelly Farm, St. Eloi on 27-28 February

\footnotetext{
${ }^{48}$ Cook, At the Sharp End, 296.

${ }^{49}$ Ashworth, 21.

${ }^{50}$ Cook, At the Sharp End, 291.

${ }^{51}$ Cooke, 70.

${ }^{52}$ Canadian Letters and Images Project (hereafter referred to as CLIP), Charles Henry Savage, memoir, 1916. This online database of letters and memoirs from Canadian servicemen can be found at www.canadianletters.ca.
} 
1915. ${ }^{53}$ Shortly after their arrival on the Western Front in December 1914, the PPCLI was in the trenches of the southern part of the Ypres salient. The Germans opposite the Patricia's were digging a sap, or parallel fire trench projecting out into No Man's Land, and were possibly going to use it as a "jumping off point" in a future offensive.$^{54}$ Lieutenant-Colonel Francis Farquhar, the PPCLI commander who wanted to meet "aggression with aggression," requested from his brigade commander that he be able to lead a minor operation against this sap. "The attack was undertaken with a view of giving a setback to the enemy who, from the sap opposite...had become very aggressive and was doing considerable damage," wrote Farquhar. ${ }^{56}$

Colonel Farquhar needed ample intelligence for the operation, so that his men knew as much as they could about the enemy and their patrol patterns, strongpoints, and the topography of the trench system. Therefore, Lieutenant Colquhoun, the battalion sniping officer, was sent out on the evening of 27 February to survey the area thoroughly. ${ }^{57}$ According to an official report, Colquhoun "brought back valuable information regarding the enemy's trenches." then went out once more that night shortly before midnight, accompanied by the second-incommand Major Hamilton Gault, to reconnoitre the German trenches more closely. Once within the enemy's trenches, they separated. Their reconnaissance was very difficult for it was a bright moonlit night. ${ }^{59}$ Major Gault managed to reconnoitre to the left of the proposed point of attack, and eventually returned to friendly lines with his information. Lieutenant Colquhoun was not so fortunate; during his reconnaissance, a German working party captured him. ${ }^{60}$ This left Colonel

\footnotetext{
${ }^{53}$ Sandra Gwyn, Tapestry of War: A Private View of Canadians in the Great War. (Toronto: Harper Collins Ltd., 1992), 143.

${ }^{54}$ Hodder-Williams, 30.

${ }^{55}$ Ibid, 30 and Gwyn, 146.

${ }^{56}$ LAC, WD, PPCLI, Appendix XIV "Attack on German Sap," February 28, 1915.

${ }^{57}$ Hodder-Williams, 31.

${ }^{58}$ LAC, WD, PPCLI, Appendix XIV “Attack on German Sap, 'Note \#5, ”' February 28, 1915.

${ }^{59}$ Hodder-Williams, 31.

${ }^{60}$ LAC, WD, PPCLI, Appendix XIV “Attack on German Sap," February 28, 1915.
} 
Farquhar blind as to the particulars of this section of trench, but he proceeded with the operation, for the information that Major Gault relayed to him was deemed sufficient for the execution of the main operation. ${ }^{61}$

The raiders were divided into three groups. ${ }^{62}$ Lieutenant C.E. Crabbe, who was in charge of the entire operation, led a party of thirty snipers and riflemen, with a small attachment of bombers under the command of Lieutenant Talbot Papineau. ${ }^{63}$ This was the main assault section of the raid. The second section, under the command of Sergeant S.V. Patterson, "was to follow the main party, protect the rear...act generally as a support and cover withdrawal." ${ }^{, 64}$ A further platoon was to be in reserve under Sergeant-Major C. Lloyd, and was to move forward into the enemy trench once it was secure to demolish the German parapet, which was one of the objectives of the raid. ${ }^{65}$ In total, the raiding parties numbered less than a hundred men, but this was a very large engagement for any operation outside that of the full-scale battles.

Shortly before dawn, the raiders moved across No Man's Land, infiltrating to the "jumping off point." This was the position where they would wait for the moment to storm the German trenches. At 0515 they rushed into the enemy sap. ${ }^{66}$ Lieutenant Papineau remembered, "I was pretty scared! My stomach seemed hollow." ${ }^{67}$ It was time for the Canadians to strike back at the Germans after weeks of being pounded by German artillery and trench mortar fire.

"I had a bomb ready in my hand," wrote Papineau. "We lay for a moment exposed and then suddenly we were all up and rushing forward...I set my fuse and hurled my bomb ahead of me. From that moment, all hell broke loose." While Papineau was fighting at the lip of the

\footnotetext{
${ }^{61}$ Hodder-Williams, 32.

${ }^{62}$ LAC, WD, PPCLI, Appendix XIV “Attack on German Sap," February 28, 1915.

${ }^{63} \mathrm{Ibid}$.

${ }^{64}$ Hodder-Williams, 32-33.

${ }^{65}$ LAC, WD, PPCLI, Appendix XIV “Attack on German Sap," February 28, 1915.

${ }^{66}$ LAC, WD, PPCLI, Appendix XIV "Attack on German Sap, 'Note \#3,"” February 28, 1915.

${ }^{67} \mathrm{Ibid}$.
} 
German trench with his small bombing platoon, the major assault party under Lieutenant Coleville Crabbe forged ahead into the trench, encountering an enemy that "were completely surprised and [who] offered little resistance" ${ }^{68}$ The raiders in the main assault party stormed down the German trench for some 80 yards, until a Canadian raider was killed by some Germans who were defending a "trench block" of sandbags and wood. This block stopped Lieutenant Crabbe's assault squad's advance and they did not press the position any further. ${ }^{69}$

While Lieutenant Crabbe and his assault party were engaging the German blockade, Papineau and his small party of bombers on the trench lip continued to fight the rest of the German garrison in the area. "I fired into the trench at whatever I thought was there...I looked behind me and could see only one man apparently wounded or dead near me. I thought, 'The attack has failed. I am alone. I will never get out." ${ }^{, 70}$ Battlefield communications during the Great War were primitive at best. Keeping in touch with those storming the trenches proved to be a nearly insoluble problem for commanders tasked with controlling their units on the battlefield. Once engaged, there was also very little effective inter-unit communication due to wireless sets being technologically too cumbersome to accompany an assault. ${ }^{71}$ Therefore, it was perfectly understandable, amid the chaos of the raid and the din of the machine guns, that Lieutenant Papineau felt almost alone against the Germans. This early assault laid almost all of its success not upon planning, coordination, and an ironed-out tactical doctrine, but rather the individual determination of men like Papineau to have the stomach to keep fighting - even though they had no idea how other sections were faring, or whether the raid had succeeded or failed.

\footnotetext{
${ }^{68}$ Hodder-Williams, 33.

${ }^{69}$ LAC, WD, PPCLI, Appendix XIV “Attack on German Sap, 'Note \#3,"” February 28, 1915.

${ }^{70}$ Talbot Papineau, letter to mother, 1915, quoted in Gwyn, 144.

71 Bill Rawling, "Communications in the Canadian Corps, 1915-1918." Canadian Military History, Vol. 3, No. 2, (Autumn 1994), 10.
} 
The raid had actually not failed. Papineau was eventually joined by Lieutenant Crabbe's assault section, which had returned after being repulsed by the block, and together they proceeded with the main objective of the raid, which was to recon the area and inflict casualties: "Crabbe and I went over the edge into the trench...A German was lying in front of me. I pushed his head down to see if he was dead. He wasn't. I told a man to watch him." ${ }^{, 72}$ The raid was progressing, and along with Lieutenant Crabbe's assault party, the last platoon began to clear the rear face of the sap and trenches that ran deeper into the enemy lines. This phase of the attack would later be known as part of the "moppers up" units, and they acted as a wave that passed through the trenches, making sure that the German soldiers were indeed dead and not simply hiding. They also engaged in dropping explosives down dugout steps to make sure everyone inside was dead, and that the Canadians would not find enemy forces either behind them or in their ranks (as they popped up from underground hiding places).

The operation was running out of time, with the darkness cut by dawn and German troops likely soon to counterattack, so Colonel Farquhar passed along the order to Lieutenant Crabbe to withdraw at $0530 .{ }^{73}$ He needed to get his men to safety, and the raid was seemingly successful as a reconnaissance in force. As Papineau commented "We were told to evacuate the trench. I passed the order, then climbed out and made a run for our own line." ${ }^{, 74}$ The raiders' retreat back to friendly lines was chaotic. "Another man and I went over head first. The man that came after me was shot through the lungs. The next man got it in the stomach...I had to get back to my own trench. I beat it across the open expecting to get it any minute. I was so exhausted I wobbled from side to side in the mud." ${ }^{, 75}$ The raiding party eventually made it back to their own lines,

\footnotetext{
${ }^{72}$ Talbot Papineau, letter to mother, 1915, quoted in Gwyn, 144.

${ }^{73}$ Ibid, 34.

${ }^{74}$ Talbot Papineau, letter to mother, 1915, quoted in Gwyn, 144.

${ }^{75}$ Talbot Papineau, letter to mother, 1915, quoted in Gwyn, 145.
} 
with a total casualty count of five killed, nine wounded (including Major Gault and Lieutenant Crabbe), and three others missing. ${ }^{76}$

Despite some apparent shortcomings in planning and execution, this early raid anticipated some of the characteristics of what would form the staple components of Canadian raiding by mid 1916: "the sudden assault by a handful of troops on a small section of the line; the division of the attacking force into small groups, each with a special task; the systematic destruction of a trench; the attempt to secure prisoners for identification the withdrawal before the enemy could counterattack, after inflicting upon him all possible damage." ${ }^{97}$ The raid also captured the attention of General Sir John French, commander of the BEF, among many other military commanders, who expressed interest in the attack. ${ }^{78}$ The day of 27-28 February 1915 marked the birth of Canadian raiding, sparking the development of what would eventually become a Canadian "specialty."

The historical record of this specific action also brings to light telling evidence concerning the ambiguous nomenclature ascribed to trench raids, especially early ones such as the Shelley Farm Raid. The War Diary and its accompanying appendix refers to the event as an "attack;" the battalion history describes it as an "enterprise," "reconnaissance in force," a "raid," and an "attack;" while historian Sandra Gwyn refers to the event as a "local attack," a "raid," and a "reconnaissance in force."79 All of these terms are describing the same event, an early trench raid. This confusion in nomenclature only deepened as the number of raids multiplied.

Within these early raids, one can see the underlying nature of attacking an enemy using stealth and surprise to achieve a local, minor tactical victory. These attacks demonstrated that the

\footnotetext{
${ }^{76}$ LAC, WD, PPCLI, Appendix XIV "Attack on German Sap, 'Note \#6, '” February 28, 1915.

${ }^{77}$ Hodder-Williams, 30.

${ }^{78}$ Hodder-Williams, 35.

${ }^{79}$ Gwyn, 143. Hodder-Williams, 30-33. LAC, WD, PPCLI, February 28, 1916. LAC, WD, PPCLI, Appendix XIV

"Attack on German Sap," February 28, 1915.
} 
Canadian soldiers had the will and desire to execute on operation to achieve psychological and tactical superiority on the battlefield. The newness of trench warfare on the Western Front battlefield, however, meant that the raiders did not have the tools or doctrine in place to properly plan, prepare, and execute these attacks in an efficient and effective manner. The PPCLI, for example, did not have a timetable for the raid, or a plan for their withdrawal. In addition, the concrete operational benefits of these early operations remained unclear, for they did not capture any ground and sometimes they had prohibitive cost associated with them in terms of lost Canadian soldiers' lives. However, as the fighting continued, raiding became much more important to the offensive operations, impacting how major battles were fought and supporting the strategic policy of attrition.

\section{Petit Douve Raid, 16-17 November 1915}

The raid carried out by the PPCLI in February 1915 was technically the first raid by a Canadian combat unit, but the PPCLI was then serving within a British division and therefore not part of a larger Canadian formation. The first planned and organized raid by a Canadian Division was conducted by the $5^{\text {th }}$ and $7^{\text {th }}$ Battalions on the night of $16-17$ November 1915. It was staged at Petit Douve Farm, located in the Ypres salient. ${ }^{80}$ This raid featured thorough planning of all aspects of the preparation and execution of the raid, and set the tone for Canadian raids that would follow throughout the war. It was, according to General Sir Douglas Haig, commander in chief of the BEF after replacing General Sir John French in December 1915, a "model raid."

The operation was planned in meticulous detail. Concrete objectives were outlined; systems of support, logistics, weaponry, and timetables were all clearly defined. Planning for the Petit Douve raid was so extensive, in fact, that the official battalion war diary first makes

\footnotetext{
${ }^{80}$ Andrew Iarocci, Shoestring Soldiers: The First Canadian Division at War, 1914-1915. (Toronto: University of Toronto Press, 2008), 260.

${ }^{81}$ Cook, At the Sharp End, 293.
} 
mention of it in June of that year. ${ }^{82}$ As the time for the raid approached, scouts made many patrols to reconnoitre the German lines at Petit Douve Farm. Some interesting observations were made concerning "[sic]...the increasing tameness of the enemy - the whole of No Man's Land is absolutely ours - and our patrols have gone up to his front line, walked up his parapet...thrown bombs into his trench... our offensiveness increases daily - both by artillery and infantry operations. ${ }^{, 83}$ It was clearly important to dominate No Man's Land and maintain aggressive behaviour in elite units such as the $7^{\text {th }}$ Battalion. Both of these qualities were essential elements to raiding. The war in No Man's Land had to be won before the battle for the enemy trenches could begin in earnest.

On 15 November official orders were drawn up, detailing the attack. The intention of the raid was to make an effort at "discovering the enemy's strength and gaining information concerning his defences. ${ }^{\prime 84}$ The location of the raid was selected to maximize the element of surprise and minimize casualties, both on the approach to the target and during the withdrawal. German listening posts had been abandoned in the area due to aggressive patrolling, but the enemy had laid extensive belts of wire. Nonetheless, the Canadians planned to attack this strongpoint in the hope that the enemy would be complacent in his fortress. ${ }^{85}$ Evidence of organization is apparent even in standard of dress: all the raiders were to wear black balaclavas, gloves, no reflective objects, and no greatcoats. ${ }^{86}$ Combat dress was very important to trench raiding, as stealth was vital to ambushing the enemy and achieving surprise. The raiders also

\footnotetext{
${ }^{82}$ LAC, WD, $7^{\text {th }}$ Infantry Battalion, June 1915.

${ }^{83}$ LAC, WD, $7^{\text {th }}$ Infantry Battalion, 31 October 1915.

${ }^{84}$ LAC, WD, $7^{\text {th }}$ Infantry Battalion, "Operation Order no.59," 15 November 1915.

${ }^{85}$ LAC, Department of Militia and Defence [hereafter referred to as RG9], v.4106, Folder 22, File 5 [22/5]

"Appendix IV: Report on Minor Operation, 'Point of Attack,"” 19 November 1915.

${ }^{86}$ LAC, RG9 v.4106, 22/5, “Appendix III: Operation Order No. 59 by Lt. Col. V.W. Odlum,” 15 November 1915.
} 
were ordered to remove identifying badges and "any...articles which might disclose information to the enemy."

The assault force was divided into separate attack groups of scouts, grenadiers, wire teams, shovel men, bridge carriers, and riflemen. In total the raiders numbered just under 200 officers and men from both battalions. ${ }^{88}$ Each section had its own distinct duties and areas of operation in concert with the main body of the attack, with each individual "part" supporting the "whole." ${ }^{, 89}$ Support fire would be heavy, with preparatory strikes by "A" Battery, Royal Canadian Horse Artillery, to cut wire in front of the attacking battalions. There was also to be additional support from machine gun teams and trench mortars. ${ }^{90}$ The planning was thorough, and the result was an operation that unfolded, at least where the $7^{\text {th }}$ Battalion was concerned, with nearly textbook precision.

On the night of the operation, the raiding parties from the $5^{\text {th }}$ and $7^{\text {th }}$ Battalions slipped quietly into the night. While traversing the 250 yards of No Man's Land, the $5^{\text {th }}$ Battalion encountered some unbroken barbed wire and was discovered by an alert sentry whilst in the process of trying to cut through. Due to poor prior intelligence gathering concerning this wire, the $5^{\text {th }}$ Battalion's raiders were forced to retire in the face of German small-arms fire, yet no casualties were sustained. ${ }^{91}$ Without the element of surprise, it would have been folly to press the attack on an alert enemy, which would have degenerated into a costly frontal attack. However,

\footnotetext{
${ }^{87}$ Ibid.

${ }^{88}$ Cook, At the Sharp End, 292.

${ }^{89}$ Iarroci, 261, and LAC, RG9 v.4106, 22/5, "Appendix III: Operation Order No. 59 by Lt. Col. V.W. Odlum," 15 November 1915.

${ }^{90}$ LAC, RG9 v.4106, 22/5, "Appendix III: Operation Order No. 59 by Lt. Col. V.W. Odlum," 15 November 1915.

${ }^{91}$ Cook, At the Sharp End, 293, and Iarocci, 261. See also Dan Jenkins, "Other Side of the Hill: Combat Intelligence in the Canadian Corps, 1914-1918." Canadian Military History, Vol. 10, No. 2 (2001), 18.
} 
the four officers and 35 N.C.Os and other men from the attack parties of the $7^{\text {th }}$ Battalion were not spotted and continued forward. ${ }^{92}$

The $7^{\text {th }}$ Battalion raiders stormed through the German barbed wire. Once inside they split into their assigned parties and proceeded to assault the German trenches with deadly efficiency. They used grenades, bayonets, pistols, and rifles to clear out the trenches left and right, killing and injuring many of the unprepared troops of the $11^{\text {th }}$ Reserve Brigade. ${ }^{93}$ The raiders continued the assault for a further 19 minutes, tossing grenades into dugouts filled with enemy soldiers, and then commenced with their timely withdrawal back to their own lines. Twelve dazed Germans were taken prisoner and moved to the rear. ${ }^{94}$

As the raiders retreated along the bank of the Douve River, the supporting artillery fired on the German troops that were concentrating for their predictable counterattack, as they believed that the attackers were attempting to hold their trenches. ${ }^{95}$ They did not suspect that the Canadians had already left the lines and so they charged into the screen of artillery fire, suffering massive casualties. The raiders estimated they had killed more than 30 Germans, wounded many others, and returned with 12 prisoners. Even more Germans were caught in the deadly "box barrage" that covered their withdrawal, which used lethal shrapnel and high explosive artillery bombardments shaped into a "box" pattern that both screened the attacking raiders and also shattered oncoming German reinforcement efforts. ${ }^{96}$ With only one fatal casualty due to friendly

\footnotetext{
${ }^{92}$ LAC, RG9 v.4106, 22/5 "Appendix IV: Report on Minor Operation, 'General Summary,"' 19 November 1915.

${ }^{93}$ LAC, RG9 v.4106, 22/5 "Appendix IV: Report on Minor Operation, 'General Summary,"” 19 November 1915, and Iarocci, 261.

${ }_{94}^{94}$ Cook, At the Sharp End, 293.

${ }^{95}$ Iarocci, 261.

${ }^{96}$ LAC, RG9 v.4106, 22/5 "Appendix IV: Report on Minor Operation, 'General Summary," 19 November 1915, and Iarocci 261.
} 
fire, and another Canadian who was slightly wounded, the operation was an outstanding success. ${ }^{97}$

There were significant lessons that were learned from this raid: careful planning and preparation were vital to the infantry assault; artillery cooperation with assault teams was crucial; detailed scouting patrols were essential for reconnaissance and wire cutting; and skilled raiding specialists were also considered essential to successful operations. ${ }^{98}$ The after-action report submitted by the $7^{\text {th }}$ Battalion went into extensive detail in analysing the raid, and offered lessons for improving future operations. Special attention was paid to scouting, which was seen as important to the proper training and planning of the enterprise. "So completely were the preparation made that when the night of the attack came everything and every party was in its place," observed the operational report. ${ }^{100}$ Important "lessons learned" documents like this were circulated among the Canadian forces and, in this case, throughout the British army, to share success and failure, and ultimately to hone the art of the raid. ${ }^{101}$ One of the lessons from the raid was that the $5^{\text {th }}$ and $7^{\text {th }}$ Battalions planned the operation according to their own schedule and their local knowledge of the battle-space, yet this would change in the latter eras of raiding as the operations became more standardized and planned not from the "bottom up" but from the "top down."

With the success of the Petit Douve raid, one might assume that the lessons might be beneficial to the planning of subsequent major operations. But the learning curve of battlefield operations during the Great War was anything but a straightforward affair of constant

\footnotetext{
${ }^{97}$ Ibid.

${ }^{98}$ Rawling, Surviving, 50, and LAC, RG9 v.4106, 22/5 "Appendix IV: Report on Minor Operation, 'Reasons for Success,"” 19 November 1915.

${ }_{99}^{99}$ LAC, RG9 v.4106, 22/5 “Appendix IV: Report on Minor Operation, "General Summary,"' 19 November 1915.

${ }^{100}$ LAC, RG9 v.4106, 22/5 “Appendix IV: Report on Minor Operation, 'Attack Practice,"” 19 November 1915.

${ }^{101}$ Tim Cook, The Madman and the Butcher: The Sensational Wars of Sam Hughes and General Arthur Currie. (Toronto: Penguin, 2010), 142.
} 
improvement bred from experience. Although lessons passed up the command ladder, there was certainly no guarantee that they would find their way into new tactics, as raids at this stage were not centralized and still originated, for the most part, from within individual units. The BEF high command, however, was at least requesting input from the front line units, and had been doing so since February 1915. As historian Kenneth Radley notes, "the search for lessons became constant and insistent, the BEF being just as diligent as the enemy in its search. After every battle or action commanders expected to be asked, 'To what do you attribute the success (or failure)?' and 'What lessons can be drawn?'",102 In March 1916, the British army commanders distributed a significant document, S.S. 107: Notes on Minor Enterprises. ${ }^{103}$ This doctrinal guide, compiled and analysed by the General Staff, contained notes that had been "compiled as a result of the experience gained in certain minor operations" $" 104$ Considering that raiding was relatively new to the battlefield, the document noted that "no definite rules for the conduct of such operations can be laid down, but the suggestions contained in these notes may be useful as a guide in future enterprises." ${ }^{105}$ The manual contained details on many facets of raiding, including: general principles such as choice of objective and guidelines in reconnaissance and resources to be allocated, preparations and planning, training, dress and weaponry, allocation of tasks, support of the attack, and many other points. ${ }^{106}$

There were other guidelines and notes that circulated throughout the war. For example, one February 1916 General Staff document listed many suggestions, ranging from the employment of aerial photography and detailed reconnaissance sketches for studying trench

\footnotetext{
${ }^{102}$ Kenneth Radley, We Lead, Others Follow: First Canadian Division 1914-1918. (St. Catherines: Vanwell Publishing Ltd., 2006), 87.

${ }^{103}$ LAC, RG9, v.3858, 82/1, "S.S. 107: 'Notes on Minor Enterprises'," March 1916.

${ }^{104}$ Ibid.

${ }^{105}$ Ibid.

${ }^{106}$ Ibid.
} 
systems, to the usage of revolvers along with other special equipment such as hand-to-hand weapons, and the importance of their use in raids and how these weapons would best be employed. ${ }^{107}$ Drawn from the ranks of men who planned and executed the first raids, these detailed analyses were disseminated throughout the Canadian battalions, which allowed for the efficient sharing of experiences, knowledge, effects of experimentation, and valuable insights into the fine art of trench raiding.

\section{Raiding and Live and Let Live}

Raiding played a pivotal role in shattering informal truces between warring parties that sprang up periodically on the Western Front. No soldier wanted to die, and many sought to preserve their lives and that of their comrades by avoiding action that would provoke the enemy. According to historian Tony Ashworth, these informal truces on the battlefield, labelled live and let live, were widespread and endemic throughout the BEF. Live and let live could manifest itself in three different ways: fraternization, inertia, and ritualization. ${ }^{108}$

Fraternization typically revolved around soldiers making peaceful exchanges with the enemy, usually by talking across narrow parts of No Man's Land. ${ }^{109}$ While the Canadians enjoyed a reputation as rough colonial soldiers, individuals were sometimes known to converse with the enemy. ${ }^{110}$ But this seems to have been a rare occurrence. Sidney Hampson of the $10^{\text {th }}$ Battalion recounted an occasion when the Germans "attempt[ed] to fraternize, shouting across friendly greetings but soon stopped on receiving no reply." "The Canadian battalions fell into Ashworth's categorization as elite troops and were not likely to engage in extensive

\footnotetext{
${ }^{107}$ LAC, RG9, v.3858, 82/1, "Deductions from Recent Minor Operations," 3 February 1916.

${ }^{108}$ Ashworth, 39.

${ }^{109}$ Ashworth, 21.

${ }^{110}$ Cook, At the Sharp End, 272.

${ }^{111}$ CLIP, Sidney Hampson diary, 31 December 1915.
} 
fraternization. ${ }^{112}$ "The Germans made several attempts to fraternize, but were met with rifle and machine-gun fire," noted Lieutenant V. Curran in a letter on 3 January 1916, “...we had strict orders about hobnobbing with them." 113 This is not to say that instances of fraternizing with the enemy did not happen, but they seem to be less common in elite units. Corporal Clarence Waterman, writing a letter home on 31 December 1915 , remarked that "On the $25^{\text {th }}$ there was no such weakness as was indulged in last year, and any Hun who started across 'No Man's Land' to shake hands found himself out of luck. We worry and harass them by every means in our power as an indication...of the relentless nature of the treatment we are ready to mete out to them." 114

Inertia was a more complex method of live and let live. It was a means of indirect communication between the combatant parties, and resulted in both sides taking steps to avoid provoking the other into aggressive action. A form of inertial live and let live might be, for example, the non-retaliation for an incoming artillery bombardment, or overtly neglecting to take aggressive action against the enemy despite ample opportunity to do so. Sometimes raiding invited inertia in the enemy. Private Donald Fraser of the $31^{\text {st }}$ Battalion recalled an episode where inertia was proposed by the enemy as a reaction to a Canadian raid "Since the attacks Jerry has been extremely nervous...his nerves are on edge...They cried over to our battalion that they would not strafe us, if we would not strafe them." ${ }^{115}$ This practice was contradictory to the established ethos of the "offensive spirit," and command was well aware of its existence. During the early part of the war the high command had no official recourse other than to demand vaguely that units be "more aggressive."116 The solution from headquarters' point of view was to

\footnotetext{
112 Ashworth, 197.

${ }^{113}$ LFTF, 81 .

${ }^{114}$ LFTF, 80.

${ }_{115}$ Donald Fraser, The Journal of Private Fraser 1914-1918: Canadian Expeditionary Force. (Victoria: Sono Nis Press, 1985), 90.

${ }^{116}$ Ashworth, 42.
} 
systematize raiding as a standard offensive tactics throughout the BEF. This was done in early 1916, and served to be an effective tool to combat live and let live because it made aggression mandatory. ${ }^{117}$ Sergeant Charles Savage of the $5^{\text {th }}$ C.M.R. recalled this strategic shift: "Orders called for the maximum activity on this front, and raids...were the result. Naturally the Germans retaliated and within a few days of our arrival what had apparently been a nice quiet front had been turned into a regular hellhole." 118 This systematization of raiding, combined with both increased technological and tactical specialization, and the rise of the influence of extremely aggressive commanders known informally as "fire eaters" or "thrusters," made for an increase in aggression on the battlefield.

Thrusters were glory-seeking officers of an aggressive mindset, who sought to harass the enemy at every opportunity. These were the men who organized ad hoc aggressive patrols to attack the enemy's morale and manpower. Thrusters were not always appreciated by the lower ranks, however, as their aggressive spirit could wear on even battle-hardened soldiers. Private John Becker of the $75^{\text {th }}$ Battalion stated flatly: "I know there were some fire-eaters out there who were strong for getting on with the war - I wasn't one of them. I had all the bravery knocked out of me those first few days." ${ }^{119}$ Despite not being popular with some of their men, these thrusters were quick to be noticed by senior commanders, who appreciated their spirit for active trench warfare, and thus many were promoted to command positions. ${ }^{120}$ The combination of recognition by higher command, elite units wanting to preserve their status amongst their fellow units, and the rise of thrusters all combined to combat inertial live and let live.

\footnotetext{
${ }^{117}$ Ashworth, 82.

${ }^{118}$ CLIP, Charles Henry Savage, memoir, 1916.

119 John Becker, Silhouettes of the Great War: The memoir of John Harold Becker, 75 ${ }^{\text {th }}$ CEF, 1914-1918. (Ottawa: CEF Books, 1998), 82.

${ }^{120}$ Ashworth, 92.
} 
Ritualization involved the relegating of aggressive acts to an easily predictable format in order to facilitate an unspoken discourse of peaceful intentions. ${ }^{121}$ These acts of informal peace developed as a reaction to the standardization of aggression, notably raiding and patrolling, and involved compliance with official patterns of aggression, but followed a method that was less harmful or deadly to the enemy. This facet of live and let live functioned on the principle of reciprocation - if one side participated it might stimulate the other to do so as well. ${ }^{122}$ On rare occasions ritualized forms of live and let live were embraced by even the hardest of trench fighters. While serving in the Ypres Salient in early 1916, Sergeant Charles Savage from the $5^{\text {th }}$ C.M.R. relished a moment of ritualized peace with the enemy "On this front a sort of gentlemen's agreement seemed to exist about the breakfast hour, and it was the one time in the day that was always quiet.",123

Within the context of raiding this ritualization revealed itself through "soft" raids. A soft raid was a form of ritualized raid where the raiders, after leaving the trenches for the attack, avoiding attacking the enemy and usually sheltered in a shell crater until it was convenient for them to return after the "failed" raid. The raiders then would doctor the operations report to their superiors, claiming that enemy strength might have been stronger than anticipated or that the Germans were alert and prepared for the attack. To prove that the raiders or patrollers had done their job in visiting the enemy lines, barbed wire was often produced as a piece of tangible evidence, although most raiders kept German wire in a secret stash to ensure that they indeed did not have to stray too close to the opposite lines. In the historical records it is extremely difficult to spot a soft raid versus one that merely was poorly executed or was cancelled due to

\footnotetext{
${ }^{121}$ Ashworth, 106.

${ }^{122}$ Ashworth, 101.

${ }^{123}$ CLIP, Charles Henry Savage, memoir, March 1916.
} 
circumstances that made the likelihood of disaster certain in the eyes of the officer in charge of the raid.

When it was clear that raiders were employing soft raids, the high command responded by demanding from the raiders the one thing they could not fake: captured prisoners. This was the reason the vast majority of the raids ordered from mid-1916 onwards required a prisoner or concrete identification be secured as a primary objective. Some raiders still found ways to avoid the danger and violence. Lieutenant James Pedley from the $4^{\text {th }}$ Battalion recounted an episode where, after a raid had failed to procure a prisoner, and Battalion Headquarters ordered a followup operation as a result, his unit captured a German sentry who had gotten lost in No Man's Land. In order to avoid another raid, Lieutenant Pedley immediately reported to his commander: "There was the great moment at battalion H.Q., when the colonel...fumbled through all the letters and papers, eager as a child...Of course he had heard over the telephone what had happened, but these were visible proofs. A messenger was dispatched at once to brigade, and next day's communiqué told how the $4^{\text {th }}$ Battalion had taken two prisoners. At least, the communiqué said that we had taken them, but did not tell how." 124 The number of Canadian casualties was another way to measure an operation, especially if it failed to achieve its objectives, and there were no reported casualties. ${ }^{125}$ This raised concerns at headquarters up the chain of command. By severely impacting levels of live and let live, raiding not only had an impact on the tactics and technology of trench warfare, but also on the negotiated discourse of violence on the battlefield.

\section{Raids on the Messines/Ploegsteert Barricade, December 1915}

News of the exploits at Petit Douve circulated quickly throughout the BEF, and soon a spirit of competition encouraged other commanders to organize raids of their own. One such

\footnotetext{
${ }^{124}$ Pedley, 275. Italics are the authors.

125 Ibid.
} 
enterprise was undertaken by the Lord Strathcona's Horse [L.S.H], and took place at a position called The Barricade on the Messines/Ploegsteert road on the night of 8-9 December 1915. Although the L.S.H. was traditionally a cavalry unit, the tactical conditions of the battlefield dictated that they become a dismounted unit alongside their regular infantry brethren. The objectives of the raid were "to attack and bomb the Germans in the trench behind the Barrier...to capture a prisoner...to lay a charge of Gun-Cotton in the barrier... to be exploded." ${ }^{126}$ Scouting of the barrier was done in the days prior to the operation, and it was deemed to be lightly defended. Preparations were made by forming assault parties, cover patrols on the flanks, and machine guns in support. ${ }^{127}$ It was considered to forego artillery support for the initial assault, to better preserve the element of surprise for the infiltrating raiders.

The attack was planned with a small patrol of three scouts leading the assaulting party of one officer and 12 men, five of whom were dedicated grenadiers outfitted with extra grenades. ${ }^{128}$ They had a difficult time of sneaking up to the barrier, for "the night was very still, and it was most difficult to make any movement unheard." ${ }^{\prime 129}$ When Lieutenant Gault, the officer leading the raid, and two of his party neared the barrier they encountered a full garrison of German soldiers. In the chaos that ensued, grenades were thrown in rapid succession, and "the surviving Germans threw out...very large bombs. These bombs must have contained a very large explosive charge...Lieutenant Galt and the two leaders appear to have been killed by [these] explosions.."130 The Canadians were not able to force their way into the German position. They were then beset

\footnotetext{
${ }^{126}$ LAC, RG9, v4017, 34/16, "Report on Minor Operations Carried Out By 'Lord Strathcona's Horse' On Night December $8^{\text {th }} / 9^{\text {th }}, 1915, " 9$ December 1915.

${ }^{127}$ Ibid.

${ }^{128}$ LAC, RG9, v4017, 34/16, "Report on Minor Operations Carried Out By 'Lord Strathcona's Horse' On Night December $8^{\text {th }} / 9^{\text {th }}, 1915$, 'Orders for the Attack," 9 December 1915.

${ }^{129}$ LAC, RG9, v4017, 34/16, "Report on Minor Operations Carried Out By 'Lord Strathcona's Horse' On Night December $8^{\text {th }} / 9^{\text {th }}, 1915$, 'Description of the Attack," 9 December 1915.

${ }^{130}$ Ibid.
} 
by some 40 German reinforcements from the north side of the barrier, who forced the raiders to withdraw. ${ }^{131}$

The raid had failed, although the official report filed by Brigadier-General John Seely stated that "The primary object of the enterprise was attained, since there can be no doubt that a very large number of Germans crowded in the narrow barrier must have been killed and wounded by the bombs dropped unto them..."132 With all but two of the assaulting party either killed or wounded, and there being no prisoner captured or no explosive charge set, the raid can be considered at best a pyrrhic victory, and likely an all-out failure While a number of Germans were bombed, the L.S.H. lost an intrepid leader in Lieutenant Gault as well as aggressive raiders. This was one of the most costly aspects of trench raids, as the casualties were usually the most skilled fighters. The raid had achieved its main objective, but the cost in skilled men seemed a steep price to pay.

The Canadians took stock of their failure, however, and endeavoured to put its lessons to use with another attack against the barricade on the night of the 14-15 December. This time the task fell to the $5^{\text {th }}$ Battalion, who had been unsuccessful in the Petit Douve Raid. Learning from the previous assault, the $5^{\text {th }}$ Battalion's "Operational Order \#61" called for very close cooperation between the artillery and the assaulting parties. Heavy artillery bombardments would pound the German trenches opposite during the preceding days, and increase in ferocity at zero hour in order to support the raiders. As the Barrier was in a strategic position, "the attack had to be made at night as by day the attacking parties would have come under the enfilade fire from machine guns...To ensure a successful enterprise, close co-operation by the artillery was

\footnotetext{
${ }^{131}$ Ibid.

132 LAC, RG9, v4017, 34/16, "Report on Minor Operations Carried Out By 'Lord Strathcona's Horse' On Night December $8^{\text {th }} / 9^{\text {th }}, 1915$, 'Description of the Attack," 9 December 1915.
} 
essential." ${ }^{\prime 133}$ The operation orders dictated that the assault party of the $5^{\text {th }}$ Battalion was to rush the barricade, demolish it, and also establish a listening post on their side of the barricade. ${ }^{134}$ Each of the three special parties was given combat instructions specifically for their individual role in the infiltration, assault, holding, and demolition phases of the raid. ${ }^{135}$

In the days preceding the operation, the enemy position was bombarded by artillery in order to thin the German garrison and cut the barbed wire. A scouting patrol observed the enemy lines as trench mortars lobbed explosives at the barricade in order to "make the Germans disclose their plan of defence.." ${ }^{, 136}$ At 0400 on 15 December, the covering bombardment commenced its attack, and the three assault squads, each consisting of one officer and 14 men, infiltrated No Man's Land to their jumping off point. At 0450 they were ready to assault.

The attack met with little opposition. The main resistance came from the German machine guns and artillery further to the rear, which quickly opened fire in support of their beleaguered garrison. There was a delay in getting past uncut wire, but the provisions in each of the three squads for two wire cutters each allowed for a minimum of time spent being exposed in the open to shell or small arms fire while in the vulnerable position of cutting through the wire. The assaulting parties quickly destroyed the barricade, and withdrew before they were caught in German S.O.S. artillery fire, which was expected to come crashing down on the raiders to assist in the enemy garrison's defence. Casualties for the $5^{\text {th }}$ Battalion raiders were slight, with one officer and one private slightly wounded. The survivors snatched two German prisoners and "portions of three bodies and three rifles." 137 On the Western Front, where intelligence gathering

\footnotetext{
${ }^{133}$ LAC, RG9, v.3984, 4/9, "Report on Minor Operation Night 14/15 $5^{\text {th }}$ December 1915," 15 December 1915

${ }_{134}^{134}$ LAC, RG9, v.3858, 84/1, “Appendix 'B': Operation Order No.61 by Lt. Col. G.N. Tuxford,” 14 December 1915. ${ }^{135}$ Ibid.

${ }^{136}$ LAC, RG9, v.3984, 4/9, "Report on Minor Operation Night 14/15 $5^{\text {th }}$ December 1915," 15 December 1915

${ }^{137}$ LAC, RG9, v.3984, 4/9, "Report on Minor Operation Night $14 / 15^{\text {th }}$ December 1915, 'Results,"” 15 December 1915.
} 
was difficult due to the danger of reconnoitring No Man's Land, even a body or parts of a body could provide vital intelligence information on an enemy formation.

Artillery support was central to the safe withdrawal of the raiders back to friendly lines. According to Lieutenant-Colonel George Tuxford's battle report, artillery from the $1^{\text {st }}$ Brigade, C.F.A, harassed key German defensive and reinforcement points, and machine guns covered the withdrawal of the assaulting parties. This exfiltration process apparently transpired without incident due to in-depth planning and the raiders' knowledge of the battle-space. "138 "The essential feature of the operation was surprise," wrote one officer, "By effecting a complete surprise our casualties were reduced to almost nothing."139 Comparing this successful raid to that of the L.S.H., it is not hard to see the difference between success and failure. Planning, preparation, intelligence gathering, and close cooperation with supporting elements all combined to make the $5^{\text {th }}$ Battalion's raid successful. The L.S.H. raid did not feature artillery closely supporting the raiders, and the preparation and intelligence gathering had been hurried. Although in any raid much of the success was owed to good or bad luck, in the case of the $5^{\text {th }}$ Battalion's raid they minimised dependence on luck by having ample knowledge of their battle-space and by having a well orchestrated system of combined-arms assault.

\section{The Haigian Reforms: Raiding Transitions from Ethos to Doctrine}

General Sir Douglas Haig took over command of the BEF in December 1915, and very soon sought to change the way his divisions were fighting. He was probably well aware of the alarming rate of inertia and lack of aggression in the front lines, and raiding was one of the ways he was going to fix this problem. General Haig also used raids as part of a new grand strategy of

\footnotetext{
${ }^{138}$ LAC, RG9, v.4053, 23/12, "To G.O.C., $2^{\text {nd }}$ Canadian Infantry Brigade, Capture of Enemy Advanced Barricade on Messines Road," 15 December 1915.

${ }^{139}$ LAC, RG9, v.3984, 4/9, "Report on Minor Operation Night 14/15 $5^{\text {th }}$ December 1915, Points of Interest," 15 December 1915.
} 
attrition. Haig knew that the war was not going to be won by a big breakthrough overnight, but he believed that the way to beat the Germans was through constant wearing down of their forces, materiel, and morale. ${ }^{140}$ Raiding became not only tactically vital on the battlefield, but strategically important as well. Systematized attacks all along the Western Front, from Haig's point of view, could contribute to the wearing down of the Germans to the point of collapse. ${ }^{141}$ John McNaughton, a lieutenant in the $2^{\text {nd }}$ Battalion, elucidated this point: "Numerous patrols and raids have been busy... We must keep worrying him tho[ugh] and not give him time to collect or concentrate his guns or forces." 142 Raiding provided pressure on German logistics; it also forced the enemy to concentrate his forces closer to the front, which made them vulnerable to shellfire. Raiding played a large part in attrition, both in the attacks and the fear they produced in the enemy. ${ }^{143}$ Private John Law, a machine gunner of the $19^{\text {th }}$ Battalion, recalled the tension that Canadian raids caused on German troops: "During the night some of the men went over and tied ropes to his barb wire, and at a signal all pulled together in our own trenches. Fritz hearing the noise, thought a raid was coming, vacated his front line and turned on his artillery in his own trenches...thinking of course to teach these raiders a lesson...our fellows would laugh..." Constant strain on the enemy morale and nerves was one latent goal of attrition, where the enemy would hopefully be reduced to such a state that nervous sentries saw raiding parties in every shadow or men refused to go out on offensive patrol for fear of capture. ${ }^{145}$

\footnotetext{
${ }^{140}$ Walter Reid, Architect of Victory: Douglas Haig. (Edinburgh: Birlinn Ltd., 2006), 355-56, and Ashworth, 181. For a further discussion of the role of attrition and the lack of technical change in the Great War, see Andrew Liaropoulos, "Revolutions in Warfare: Theoretical Paradigms and Historical Evidence: The Napoleonic and First World War Revolutions in Military Affairs" The Journal of Military History, Vol. 70, No. 2 (Apr., 2006), 380-382.

${ }^{141}$ Reid, 357, and Ashworth, 182 .

${ }^{142}$ CLIP, John McNaughton, letter, 20 March 1917.

${ }^{143}$ Robert Foley, "What's in a Name: The Development of Strategies of Attrition on the Western Front 1914-18" The Historian, Vol. 68, No. 4 (2006), 723-724.

${ }_{144}$ CLIP, John William Law, letter, 22 August 1916.

${ }^{145}$ Reid, 356, and Ashworth, 181.
} 
There were also political reasons for instituting raiding as part of General Haig's attrition strategy. Haig faced political pressure from the French who accused the British of not carrying their fair share of the burden in the alliance against Germany, and were calling for the BEF to conduct offensives, large and small, to relive the pressure on the French. This put Haig in a difficult position, as these preliminary set-piece battles would be largely a wasteful exercise before the planned "big push" at the Somme in the late summer of $1916 .{ }^{146}$ While the major offensives took months to plan, especially with the need to build the logistical rails, supply roads, and marshal guns and shells, raiding thus allowed Haig to keep pressure on the Germans and appease his allies. ${ }^{147}$ The casualties were indeed high for the BEF: 83,000 casualties from December 1915 to May 1916 - a time period where there were no major battles. ${ }^{148}$ Most of these casualties were likely the result of shellfire, but some were attributed to raiding, and the retaliatory effects of such actions. Therefore, in a morbid sense, the high casualty figures provided Haig with a valid case to bring to his French allies by showing that the BEF was seeing its fair share of death.

Whereas there were only a handful of raids before Haig's appointment, raiding became far more common from 1916 to the end of the war. Lawrence Earl Johns of the $58^{\text {th }}$ Battalion described these constant harassment raids: "[our battalion was] giving Fritz fits at the present time... Going over and bombing his trenches killing a few men so he is kept busy watching all the time. At night somewhere within hearing some [battalion] is teasing him first you hear a racket then he sends up colored flares to his artillery or for more men to come up."149 While frequent raiding attrited the enemy, one consequence was that the most essential element of its

\footnotetext{
${ }^{146}$ J.P. Harris, Douglas Haig and the First World War. (New York: Cambridge University Press, 2008), 206.

${ }^{147}$ Harris, 207.

${ }^{148}$ Ashworth, 184.

${ }^{149}$ CLIP, Lawrence Earl Johns, letter, 24 March 1917.
} 
success, surprise, was diminished. With raids occurring very frequently all along the front, the Germans most certainly were alert for a raid on any given night. ${ }^{150}$ Another consequence of frequent raiding was that the hurried operations did not allow for extensive and thorough preparation. When the $31^{\text {st }}$ Battalion raided on the slopes of Vimy Ridge on 29 March 1917 at Edinburgh and Zivy Craters, they encountered great difficulty in the assault, suffering casualties to concentrated enemy small-arms and shellfire. In the after-action report, the $31^{\text {st }}$ Battalion's commander concluded that his men "had a difficult time in the preparation of the scheme on short notice, and carrying it out without opportunity for practice and with troops new to the locality." 151 The earliest "model raids" featured many months of scouting, training, and planning before zero hour. Later raids provided the units with much less time for preparation. The consequences of this change in raiding strategy would have a profound effect on those were at the "tip of the spear."

\section{Spanbroekmolen Raid, Messines, 30-31 January 1916}

Despite the aforementioned problems with frequent raiding, multiple operations provided the Canadian infantry with opportunities for tactical and technological experimentation. The $28^{\text {th }}$ and $29^{\text {th }}$ Battalions performed a joint raid on the night of 30-31 January 1916 that exemplified this rapid change in tactical and technological doctrine. This raid was one of the first to be planned since the pioneering Petit Douve raid, yet changes to preparation, technology, and attack doctrine were already implemented after that pivotal attack. The impetus for this raid came from Lieutenant-Colonel D.E. Macintyre, who was the $28^{\text {th }}$ Battalion's scouting officer. His reconnaissance of the area began on 23 December 1915, at a point called Madelstede Farm. ${ }^{152}$ He went out many times into No Man's Land to reconnoitre the enemy trenches, and the vital

\footnotetext{
${ }^{150}$ Cook, At the Sharp End, 301.

${ }^{151}$ LAC, RG9, v.3858, 82/7, "Raid in German front line," 30 March 1917.

${ }^{152}$ LAC, MG30 E241, D.E. Macintyre papers, 23 December 1915, 101.
} 
diagrams and intelligence he uncovered demonstrated the importance of patrols in preparation for a raid. ${ }^{153}$ From this reconnaissance it was decided to perform a raid in order to obtain prisoners and other forms of identification. ${ }^{154}$ Instead of using artillery as a means to cut the German wire, Macintyre utilized his expert scouts to cut the wire by hand well in advance of the raiding party. This tactic was crucial in preserving the element of surprise. ${ }^{155}$

Lieutenant C.R. Myers of the $29^{\text {th }}$ Battalion recounted that the scouts on the night of 30 January "went out to cut a lane through the German wire; this was...done right under the muzzle of a machine-gun." 156 With the wire cut, the raid was clear to be executed. In his memoir D.E. Macintyre described the start of the operation: "We heard a volley of bombs and instantly the air was fully of flare rockets and the jig was up. There we were all tangled up in the wire...The alarm had been given, men were running along the walks inside, sentries were speeding up their fire so I had to act quick." 157 The attack by the $29^{\text {th }}$ Battalion alerted the

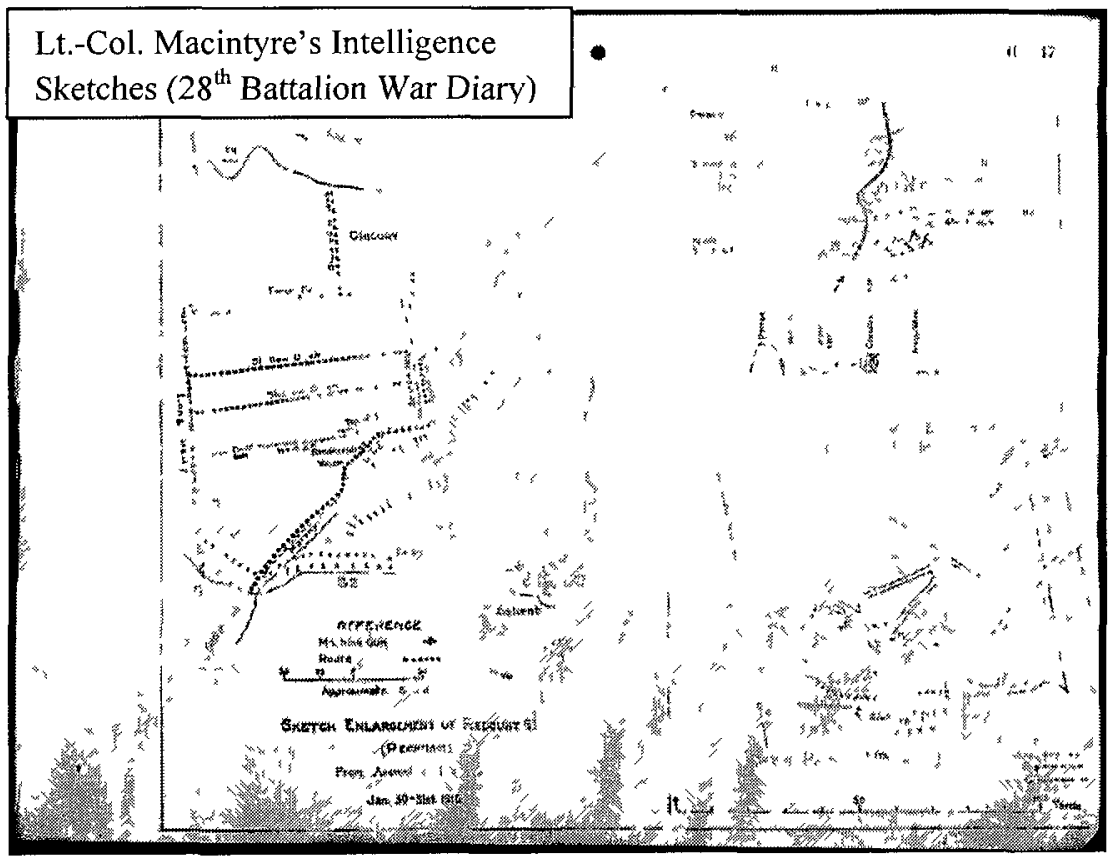

\footnotetext{
${ }^{153}$ LAC, WD, $28^{\text {th }}$ Infantry Battalion, reconnaissance sketch N24 pt61, 9 December 1915, and for Macintyre's sketch of the enemy trenches see LAC, WD, $28^{\text {th }}$ Infantry Battalion, reconnaissance sketch "Trench Cross-Section," 31 January 1916.

${ }^{154}$ LAC, RG9, v.4140, 1/11, " 6 th Canadian Infantry Brigade Order No.47," 28 January 1916.

${ }^{155}$ LAC, WD, $28^{\text {th }}$ Infantry Battalion, "General Report of G.O.C. $6^{\text {th }}$ Canadian Infantry Brigade," 3 February 1916.

${ }^{156}$ LFTF, 86.

${ }^{157}$ LAC, MG30 E241, D.E. Macintyre papers, 29 January 1916, 112.
} 
Germans on the $28^{\text {th }}$ Battalion's front, who rushed their operations to attack before all surprise was lost. Macintyre continued:

Turner, Conlin, Capt Taylor and I crawled up the great high parapet abreast and each threw a bomb over...then things began to happen quick...Almost at once Corp. Conlin was shot through the head and fell at my feet...Turner, Haylock, and I got Conlin out...It was an awful job...After that our casualties kept coming fast. All this time there was the most awful noise going on and the sky was alight with the flashes of explosions...We got two prisoners and they were both killed getting them out...[W]e ran out of their wire...All the way back out artillery kept up a terrible fire on the enemy, the guns for miles around concentrating on this point. The Germans cut loose with everything they had, but I had been figuring this thing out for two months and know exactly where they would fire if surprised and carefully kept out of those places, so I got the whole party home without any losses on the way. ${ }^{158}$ Aided by weeks of planning and preparation, and aggressive action, the Germans were "clearly taken by surprise," according to the after-action report, and there was hardly "any organized resistance." 159

The raid taught many valuable lessons. The $6^{\text {th }}$ Brigade's commander, Major-General Huntly Ketchen, remarked in his after-action report that "The possibility of successfully cutting the thick enemy wire as exists along our front, by hand, and without artillery preparation, which, if employed, does away with the element of surprise." 160 This was a valuable observation and

\footnotetext{
${ }_{158}$ Ibid, 113-114.

${ }^{159}$ LAC, RG9 v.3858, 84/3, $28^{\text {th }}$ Battalion, "General Report of G.O.C. $6^{\text {th }}$ Canadian Infantry Brigade," 3 February 1916.

${ }^{160}$ LAC, RG9 v.3858, 84/3, $28^{\text {th }}$ Battalion, "General Report of G.O.C. $6^{\text {th }}$ Canadian Infantry Brigade, 'Deductions,"” 3 February 1916.
} 
one that influenced future raids, although raiders would always have to weigh surprise against weight of fire.

\section{An Aggression Catalyst: Revenge for Raids}

Raiding elevated the level of aggression on the battlefield, especially with the enemy side engaging in revenge or retaliation operations. Although the Germans occasionally retaliated against Canadian operations with raids of their own, this was more prevalent in the latter stages of the war. In the first era of trench raiding, the Germans usually retaliated with their powerful artillery or by engaging in underground mining and the detonation of explosives. Like raids, this was a terrifying thing for soldiers, who were often aware that the enemy was working beneath the ground, steadily moving towards their trenches, and that there was little that could be done to stop the enemy. Lieutenant-Colonel D.E. Macintyre of the $28^{\text {th }}$ Battalion recounted: " ....the Germans...had intended blowing the mines a few days sooner, but heard that the $28^{\text {th }}$ were coming into the line and waited for them to get even for their 'black faces'. This referred to the night raid of $31^{\text {st }}$ Jan when we blackened our faces." ${ }^{\text {161 }}$ This attack was in retaliation for the $28^{\text {th }}$ Battalion's raid earlier on that salient, which as Macintyre described as being a revenge attack for a previous German mine attack: "[sic] Our bombs are deadly things...We killed between forty and fifty of them. The men were so wild...that they killed everyone, although they squealed and yelled 'Please Mister'...We sure got even for the mine explosion in October that night." 162 Raiding was a force in increasing the cycle of violence on the battlefield, inciting deadly retaliation and revenge from the enemy, which, in turn, only encouraged further raiding.

Even the first generation of raids, such as those undertaken by the PPCLI in February 1915, brought German retaliation. After being shocked by the Canucks, the Germans did not let

\footnotetext{
${ }^{161}$ LAC, MG30 E241, D.E. Macintyre papers, early 1916, 168.

${ }^{162}$ LAC, MG30 E241, D.E. Macintyre papers, 31 January 1916, 212.
} 
the raid go unpunished, and proceeded to pound the PPCLI positions with artillery and smallarms fire. Agar Adamson, recently promoted to command No. 2 Company, described this as "the most awful day I ever put in...I could do nothing...We just lay there huddled together with constant fire pulling our breastwork down inch by inch. I lost 6 killed and 21 wounded." ${ }^{, 163}$ With the Germans incited to retaliate whenever Canadians raided, this heightened the level of aggression and bloodshed in that sector of the battlefield.

Raids often provoked deadly retaliation from the afflicted Germans, but since counter-raids often took days or weeks to organize, the violence often fell on other "innocent" units. Alfred Andrews of the $2^{\text {nd }}$ Battalion recalled in his diary a few instances of German artillery retaliations for raids: "[sic] ...the 7th and 8th pulled off raids, and we got some retaliation...the 46th Batt. pulled a raid but our Batt. was doing working parties and got the retaliation." ${ }^{164}$ As a result, this interplay between raid and retaliation had dramatic effects on the level of violence on the battlefield. Private Donald Fraser of the $31^{\text {st }}$ Battalion remembered the extent of German retaliation for raids other units had pulled off: "The enemy retaliated for our bombing attacks with everything at his command, coal boxes, aerial torpedoes, minnewerfers, etc...Our men had to retire...for three hours till the storm subsided." ${ }^{, 165}$ Sergeant Charles Savage from the $5^{\text {th }}$ C.M.R. also remembered the consequences of inflicting a raid on the enemy: "The day after the raid the Germans retaliated on us with shell fire and trench mortars, and as there were no deep dugouts it was quite impossible to get any sleep during the day." ${ }^{166}$ The Germans had good reason to retaliate, for their trenches were being attacked in the dead of night without warning, men were

\footnotetext{
${ }^{163}$ CLIP, Agar Adamson, letter to Mabel, March 1915.

${ }^{164}$ CLIP, A.H.J Andrews diary, 27 January 1918.

${ }^{165}$ Fraser, 91.

${ }^{166}$ CLIP, Charles Henry Savage, memoir, no date, early 1916.
} 
killed in dugouts and in their sleep, and prisoners and equipment were dragged back to the Allied lines.

In many instances, the German artillery retaliation was not just focused on the units that were suspected of pulling off the raid, but adjacent battalions also were punished collectively. Sydney Amyas Winterbottom of the $7^{\text {th }}$ Battalion wrote: "The battalion on our right made a bombing raid on Fritz's lines. He came back at us with his artillery. Our post was in the thick of it for a while... none of us minded it as much as you would think." ${ }^{\text {167 }}$ If Winterbottom's account can be taken as a representative view, this might indicate that, despite the retaliation inflicted upon the Canadians due to their aggression in minor operations, many of the front line soldiers had seen worse, and such retaliation was seen as a necessary evil in order to dominate the enemy on the ground. In raiding, Canadians were asserting their authority over No Man's Land, taking ownership of that battle-space away from their adversaries, and that sense of agency on the battlefield was worth the occasional hellish retaliatory bombardment from 'Fritz.'

\section{The Raider's Arsenal: Close Combat Weaponry}

Not only did tactics and strategy change as raiding developed during the war, but the technology and weaponry the Canadians used underwent its own evolution. This was especially evident in the evolution of close combat weaponry employed in minor operations. Early Canadian raiders used a wide variety of weapons, with a high degree of improvisation and experimentation. Later, the Canadian raiders augmented their deadly arsenal with a standardized weapon system, phasing out other improvised technological developments.

In the first years of the war, raiders equipped themselves with pistols as a primary firing weapon, as rifles could be unwieldy in the confined chaos of an enemy trench. Raiders also brought along many sorts of hand-to-hand weapons. This is where the true brutality and savagery

\footnotetext{
${ }^{167}$ CLIP, Sydney Amyas Winterbottom, 13 December 1916.
} 
of trench raiding is evident, as there are surviving examples of bayonets, hatchets, maces, clubs, push-knives, and brass knuckles. ${ }^{168}$ Early in the war, these improvised weapons suited the style of stealth raiding that the Canadians were carrying out, as they were weapons that were simple to use, were ideal for silencing enemy sentries, and were able to be wielded effectively in the tight confines of an enemy trench. ${ }^{169}$ The Germans seemed to use trench clubs and "morning stars" to a greater degree than their Allied counterparts, and this may be due to the fact that the German soldier was not traditionally trained as a knife fighter. ${ }^{170}$

When the $28^{\text {th }}$ and $29^{\text {th }}$ Battalions raided Point 61 at Spanbroekmolen, Messines on 30-31 January 1916, they were equipped with the usual revolvers, rifles, and bayonets, but D.E. Macintyre made special mention that some of his men took "trench maces" and "hatchets" as personal weapons for close combat. ${ }^{171}$ However, these were not deemed as important as the number of grenades the men would carry, for each had to have at least two, and dedicated bombers carried up to 20 each. ${ }^{172}$ Lieutenant C.R. Myers of the $29^{\text {th }}$ Battalion remembered how his comrades fought during their part of the raid, where they "did good work with revolver, bayonet, and even with clubs, slaying at least fifteen Boches, after which they threw bombs into all the dugouts, where they accounted for many more." ${ }^{, 173}$ The $29^{\text {th }}$ Battalion as well experienced tense close-quarters fighting. Lieutenant C.R. Myers remembered one example where "Capt. Ken. Taylor...emptied his revolver into the first German he encountered, threw it at the head of the next, slew two more with his own bayonet, and then picked up a German saw-edged bayonet, and slew another one." 174

\footnotetext{
${ }^{168}$ Rawling, Surviving 103 . For a diagram of these improvised weapons, see Todd, 146.

${ }^{169}$ Todd, 140 .

${ }^{170}$ Todd, 147.

${ }^{171}$ LAC, MG30 E241, D.E. Macintyre papers, 29 January 1916, 107.

${ }^{172}$ Ibid.

${ }^{173}$ LFTF, 86-87.

${ }^{174}$ LFTF, 87.
} 
As raiding continued into the final years of the war, the deadly hand to hand combat continued and intensified. One popular weapon was the ubiquitous bayonet. Its use intensified due to the fact that raids were becoming more intricate and systematized, and thus a less cumbersome weapon than a mace or a club was sought. With the advent of the battle raid in late 1916-early 1917, the day of the specially equipped raider that wielded clubs, maces, "knuckle dusters," and other improvised close combat weaponry was gradually phased out. ${ }^{175}$ The reason the bayonet was used throughout the war was because it provided not only a simple shock weapon to the soldiers, but it also served a psychological motivator for the user to close the distance and attack, and for the victim to surrender or flee. ${ }^{176}$ Close combat weapons such as the bayonet, and the training in their use, not only allowed the raiders to dispatch the enemy and force him to flee or surrender, but also made the raiders more resilient combatants. ${ }^{177}$

Bayonets became a weapon for raiders to violently dispatch resisting enemy troops who had not surrendered or succumbed in the cacophony of grenade explosions. When the $20^{\text {th }}$ Battalion raided a point called The Maze in the Arras sector on 3 June 1918, the official report noted that "dugouts and shelters were bombed and all who would not surrender were bayoneted." 178 Being a preferred close combat weapon throughout the war, soldiers usually carried more than one bayonet when they raided. This paid dividends in December 1917 when the Germans raided the $24^{\text {th }}$ Battalion and captured two of its men. Private England, who was stabbed through the wrist and kicked unconscious by a German raider, was being dragged back to enemy lines following the raid when he noticed a spare bayonet in the boot-strap of his captor.

\footnotetext{
${ }^{175}$ Todd, 148.

${ }^{176}$ Robert Engen, "Steel Against Fire: The Bayonet in the First World War." Journal of Military and Strategic Studies, Vol. 8, No. 3 (Spring 2006), 2-3.

${ }_{177}$ Aaron Miedema, Bayonets and Blobsticks: The Canadian Experience of Close Combat 1915-1918. (Unpublished MA Thesis: Royal Military College of Canada, 2010), 151-152.

${ }_{178}$ LAC, RG9, v.4154, 8/1, "Summary of Raids Carried out by $2^{\text {nd }}$ Canadian Division from April to June 1918," 25 June 1918.
} 
He grabbed it, stabbed his captor and another man, and then retreated into the night. ${ }^{179}$ The fact that raiders liked to go into battle heavily armed for close combat saved Private England from becoming a prisoner. Close combat weapons were an integral part of the raider's arsenal, and their development and evolution mirrored the larger evolution of raids, from improvised and adhoc enterprises to those that were systematized and standardized throughout the Corps.

\section{Raiding Evolved: Raids into the Summer of 1916}

Where the January 1916 Spanbroekmolen Raid succeeded, other raids in early 1916 did not. For example, the $10^{\text {th }}$ Battalion executed a raid north of La Petit Douve Farm on the night of 4-5 February 1916. According to Brigadier-General L.J. Lipsett's report, while traversing the gaps that the scouts had made in the German barbed wire, the party of 50 raiders was ambushed from multiple directions. A fierce firefight ensued that eventually degenerated into hand-to-hand combat. The raiders retreated with one killed, 17 wounded, and three missing. ${ }^{180}$ BrigadierGeneral Lipsett went on to note that "considering the difficult position in which they were...I think they were fortunate in not having greater losses."181 Proper reconnaissance of the area, and the deployment of protective flanking patrols, would have forewarned the raiders of the German ambush.

This sense of awareness and careful intelligence gathering proved beneficial to the Canadians just a few days later. The $2^{\text {nd }}$ Battalion planned to raid against D-3 trench on $8-9$ February using bangalore ammonal explosive tubes to destroy the wire and create a path for the raiders into the enemy trench. ${ }^{182}$ This attack, however, was called off due to a bright moonlit

\footnotetext{
${ }^{179}$ R.C. Fetherstonhaugh, Ed. The $24^{\text {th }}$ Battalion, CEF, Victoria Rifles of Canada 1914-1919. (Montreal: Gazette Printing Co., 1930), 192.

${ }^{180}$ LAC, RG9, v.4017, 34/9, "Narrative of Minor Enterprise Carried out by the $10^{\text {th }}$ Battalion, on Night of $4 / 5^{\text {th }}$ February," 5 February 1916.

${ }^{181}$ Ibid.

${ }^{182}$ LAC, RG9, v.4016, 33/22, "Report on Minor Operations carried out on the night of $8^{\text {th }} / 9^{\text {th }}$ February, 1916," 9 February 1916.
} 
night, which would have left the raiders vulnerable. An advance patrol also observed that the Germans were "very active in their wire and also in their trenches and were very much on the alert." ${ }^{\text {183 }}$ Raids, being primarily stealth and surprise operations in the first era, were dependant on environmental factors and an unsuspecting enemy to be successful. Careful intelligence gathering saved the $2^{\text {nd }}$ Battalion from what could have degenerated into a costly frontal assault. Raiding continued throughout the spring and summer of 1916. On $29 \mathrm{July}$, the $10^{\text {th }}$ Battalion carried out another raid. It was a bold operation that was executed in broad daylight. The majority of raids took place during night in order to preserve the element of surprise, so for a raid to be executed during daylight the level of intelligence and artillery support was necessarily elaborate. Support even came from the skies, as an aeroplane was scheduled to fly over friendly lines in order to distract the enemy. ${ }^{184}$ Advanced wire cutters were sent out the night before to clear paths in the enemy wire. The raid then unfolded with clockwork precision. The raiders had a dedicated team of telephone signallers who kept them in constant communication with their supporting elements of artillery, trench mortars, and headquarters. An official report noted the "vital necessity of close communications... The fire...could be turned on or off according as the situation demanded thus ensuring...better results from the expenditure."185 The importance of communication suggested that the $10^{\text {th }}$ Battalion had learned from its past mistakes and applied the lessons to good effect.

Hard lessons were learned, and sometimes re-learned, by the different Canadian units as they continued to raid into the summer of 1916. The Royal Canadian Regiment [RCR] carried out a raid on 18 August 1916 that resulted in heavy casualties and failed to achieve its objective.

\footnotetext{
183 Ibid.

${ }^{184}$ LAC, Rg9, v.4106, 23/7, " $19^{\text {th }}$ Canadian Battalion Operation , July $28^{\text {th }}, 1916$," 28 July 1916.

${ }^{185}$ LAC, RG9, v4 106, 23/7, "Raiding Operation carried out by $19 t$ Canadian Battalion, $29^{\text {th }}$ July 1916 , supported by C.F.A.," 29 July 1916.
} 
Everything was planned accordingly, but poor intelligence gathering and bad luck led to the raiders being ambushed at their point of attack by an enemy garrison that was unexpectedly heavily-manned. Lieutenant-Colonel C.H. Hill explained in an addendum to his report to senior officers "that the party had no idea that the enemy trenches were manned so strongly." " The raiders, despite seeing they were outgunned and outmanoeuvred, still persisted in the attack. The operations report noted that when the raiders "got through the wire they were caught by enemy machine gun fire and bombs and every member of the raiding party... was either wounded or killed." ${ }^{187}$ The raid had failed to achieve its objective, and the raiders retreated with one killed and 15 wounded, three mortally so. ${ }^{188}$ Lieutenant-General Julian Byng, commander of the Canadian Corps from the summer of 1916 to June 1917, commented that "It is regrettable that this raid did not succeed in obtaining identifications and that their casualties were severe. However, I do not think that their efforts were fruitless or their bravery wasted." 189 Byng's optimistic assessment is highly debatable, with the men who lost good comrades that night likely questioning if their lives had not indeed been wasted.

The continual planning and execution of raids throughout 1916 provided commanders with a rich resource of information on how to shape the infantry attack doctrine for major assaults. Moreover, lessons learned did not stay within the Canadian divisions, which numbered three by the summer of 1916. Reports of the early raids soon garnered interest from their French allies, who in February 1916 sent a request for some of their officers to become attachés in order

\footnotetext{
${ }^{186}$ LAC, RG9, v.3858, 82/3, dispatch report, Lieutenant-Colonel C.H. Hill, "Headquarters, $7^{\text {th }}$ Canadian Infantry Brigade," 16 August 1916.

${ }_{187}$ LAC, RG9, v.3858, 82/3, "Report on Minor Operations Carried Out by the RCR on Night of $17 / 18^{\text {th }}$," 18 August 1916.

${ }^{188}$ Ibid.

${ }^{189}$ LAC, RG9, v.3858, 82/3, dispatch, "Canadian Corps G.260, Second Army," 22 August 1916.
} 
to study Canadian raiding. ${ }^{190}$ Although the battles in which the Canadians took part in during late-1916 to spring 1917 indicate a marked improvement in attack doctrine and logistical preparation compared to the blunderings of 1915 to early 1916, the extent to which Canadian raiding influenced this change remains difficult to pinpoint. However, raiding provided a wealth of knowledge, and hard-learned lessons through constant experimentation, and much of the battle-craft was later infused through the attack doctrine and logistical preparation for major assaults. The first evidence of this "trickling up" of raiding lessons being applied to the major offensives occurred after the Battle of the Somme.

${ }^{190}$ LAC, RG9, v.3865, 101/6, "Attachment of French Officers to Study Methods Used in 'Minor Night Operations,"” 22 February 1916. 
CHAPTER II: Organized Raiding, The Somme to Vimy Ridge

\section{The Somme: The Struggle to Apply Minor Operations to a Major Offensive}

The Battle of the Somme was one of the largest offensives of the entire war. Everything about the operation was on a massive scale: the battlefront, the numbers of men involved, the weight of shell in preparatory bombardments, the expenditure of ammunition in assaults, and the number of casualties sustained by the 'poor bloody infantry,' who hammered against German positions in wasteful frontal assaults. ${ }^{191}$ The Somme also served an instructional role, where the Canadians learned very hard lessons in all aspects of operations and logistics, and emerged from the other side battered and bloodied, but with a sense that they had to change and evolve or they would be ground out in future battles. ${ }^{192}$

The British preparatory bombardments of late June 1916 before the battle were gargantuan, lasting for 8 days with an average expenditure of 10,000 shells every hour. ${ }^{193}$ The artillery bombardments proved to be either inaccurate or, despite utilizing advanced techniques such as a primitive form of creeping barrage, completely uncoordinated with the infantry assault, leaving the advancing soldiers vulnerable as they traversed No Man's Land, harassed by German shells and small arms. ${ }^{194}$ The immense casualties of almost 60,000 dead and wounded on July 1 alone, including the massacre of the Newfoundland Regiment at Beaumont Hamel, were mainly due to inexperience and lack of training, rigid macro-tactics that constrained junior commanders, a divorced and uncoordinated high command with unrealistic expectations, and a complete and utter breakdown in communications. ${ }^{195}$ Despite some level of training with tactics and

\footnotetext{
${ }^{191}$ John Keegan. Face of Battle: A Study of Agincourt, Waterloo, and the Somme. (London: Pimlico, 2004), 242$243,254$.

${ }_{192}$ Desmond Morton, When Your Number's Up. (Toronto: Random House of Canada Ltd., 1993), 162.

${ }^{193}$ Rawling, Surviving, 69.

${ }^{194}$ Robin Prior and Trevor Wilson. The Somme. (London: Yale University Press, 2005), 80.

${ }^{195}$ Rawling, Surviving, 70-71, and Prior, 133.
} 
specialized weapons such as the Lewis gun, the British and Dominion troops that attacked in the summer of 1916 could only put that training into effect if the enemy had been sufficiently subdued by the British artillery bombardments. When it had not, as was often the case, assaults against an intact, prepared, and heavily armed enemy only led to stalled attacks and appalling losses. ${ }^{196}$ The emphasis was not on the combined-arms assault, as it should have been, for complete faith was placed in the artillery to smash the German positions, paving the way for the infantry to merely move in and occupy the still-smoking enemy trenches. ${ }^{197}$ Throughout the battle, the artillery failed completely in this task, and the infantry paid the price in blood.

The Canadian experience in trench raids paid dividends, however, once they got to closer range with the enemy. Battalions attacked with dedicated bombing sections attached to each company, which entered trenches and bombed as they advanced until they reached their objectives - just as they had done many times before in a trench raid. ${ }^{198}$ As the new positions were won, the riflemen supported by the bombers assaulted parallel to the enemy trench system toward each other in order to create a new continual front. The Canadians, and also many of the other BEF formations, had the infantry tactics, fighting skill, and weaponry to outfight the Germans once they reached their trenches - they just were rarely given the opportunity to do so because of poor planning and inadequate support from their artillery. ${ }^{199}$ Despite these advances, the Canadian assaults were largely inconsequential, with the whole battle turning out to be fruitless. For example, the attempt to take Mouquet Farm from 7 August to 12 September cost the British, Australian, and Canadian divisions nearly 20,000 combined casualties, and this was for an operation that had been previously abandoned by BEF high command, but had been

\footnotetext{
${ }^{196}$ Prior, 59.

${ }^{197}$ Griffith, 27.

${ }_{198}^{198}$ Rawling Surviving, 79.

${ }^{199}$ Prior, 258-259.
} 
carried out anyway. ${ }^{200}$ When the position finally fell, it had been reduced to a quagmire of rubble and mud.

In between the major assaults on the Somme, the Canadians reverted to a system of patrolling their front lines, and occasionally even raided the Germans. These were in essence minor battles taking place within larger ones, and served as ways for the Canadians to soften up the enemy before a main assault or to consolidate their lines to provide a better defensive position from which to launch further attacks. On 20 September the $58^{\text {th }}$ Battalion, in conjunction with the $43^{\text {rd }}$ Battalion, carried out a joint bombing raid on the enemy lines at Zollern Graben, just north of Pozieres. ${ }^{201}$ The object was to link up the two battalions in preparation for a subsequent assault on the main German trench lines in the sector. No prior reconnaissance was undertaken, and thus the raiders unknowingly were about to attack a very alert and prepared German position.

At 0500 the raid was launched, with the few dozen raiders storming, without artillery support, through 70 metres of enemy trench until they were thwarted by an enemy block of barbed wire and wooden boards in the trench. ${ }^{202}$ Caught in the confined space of a trench and with no room to manoeuvre or escape, the attacking raiders were ambushed with machine gun and rifle fire at close range. Casualties were extremely heavy, with 17 being listed as casualties. ${ }^{203}$ Under new command, remaining parties retreated back down the communication trench to construct a defensive block of their own. They then withdrew back to their lines, having suffered one officer and eight privates killed, 33 wounded, and 16 missing. ${ }^{204}$ Without artillery

\footnotetext{
${ }^{200}$ Prior, 184.

${ }^{201}$ Kevin Shackleton, Second to None: The Fighting $58^{\text {th }}$ Battalion of the Canadian Expeditionary Force. (Toronto: Dundun Press, 2002), 82.

${ }^{202}$ LAC, WD, $58^{\text {th }}$ Infantry Battalion, 20 September 1916.

${ }^{203}$ Shackleton, 84

${ }^{204}$ LAC, WD, $58^{\text {th }}$ Infantry Battalion, 20 September 1916.
} 
support, proper preparation and intelligence gathering, and against a prepared and alert enemy, the raid really had little chance of success from the outset.

There were numerous tactical setbacks at the Somme, including the inability to cut the enemy wire to allow the infantry to penetrate the German forward defences. This deficiency caused many casualties as the Canadians had to negotiate thick belts of wire while under tremendous enemy artillery and small-arms fire. ${ }^{205}$ Fire support for the attacking infantry was a complete failure, with artillery being uncoordinated with the infantry movements, leaving them unsupported as they attempted to tackle the formidable German defences. ${ }^{206}$ These tactical failures were merely compounded by an inept high command, which was uncoordinated, indecisive, and, especially in the specific case of General Sir Douglas Haig, highly unrealistic in overall strategy for the battle. ${ }^{207}$ After losing 24,000 Canadian casualties, the Somme, therefore, provided very hard lessons to the Canadians, mainly showing them that they had not learned enough about assault operations to overcome the German defences. ${ }^{208}$ The Somme proved at the macro level that the Great War, in the absence of strategies to break through the tactical deadlock, became a war of endurance that, through a slow and tedious attrition of men and materiel, sorely tested the soldier's resilience. ${ }^{209}$ The Canadians once more would turn to trench raids as the canvas on which they attempted to sketch out a solution to some of the problems encountered at the Somme.

\section{Learning Lessons: Raiding in the Winter of 1916-1917}

After the titanic Battle of the Somme was finally called off in November 1916, Canadian raiding continued to evolve. From late November 1916 to April 1917, there was a second era of

\footnotetext{
${ }^{205}$ Keegan, Face of Battle, 236-237.

206 Prior, 231.

${ }^{207}$ Prior, 305-306. For criticism of the uncoordinated and piecemeal assaults at the Somme, see Griffith, 15.

208 Rawling, Surviving, 82., and Morton, 163.

${ }^{209}$ Watson, 19-20.
} 
Canadian trench raiding, where Byng's forces launched more than 60 major raids. These raids allowed the Canadians to learn, adapt, and improve attack doctrine and coordinate technology. ${ }^{210}$ Although there were many diverse raids throughout the winter of 1916, a few key operations exemplify how the Canadians were engaging a tactical and technological learning environment. This evolution featured a gradual departure from an ad-hoc and elite ethos of raiding, to a systematized and standardized doctrine.

Starting in late November, Canadian raids occurred with increased frequency, with at least a few raids every week. Raids were particularly plentiful in the Souchez sector of the Western Front. The $2^{\text {nd }}$ C.M.R. raided at the unremarkable trench grid reference A.23.a.5.4 on 21 November, with the raiders advanced behind a creeping barrage of artillery shells: the same tactic that was used in the latter stages of the Battle of the Somme, and would be a prominent operational aspect of the assault on Vimy Ridge in April 1917. The combination of accurate artillery cover, and the blowing of a bangalore explosive to create a gap in the German wire, provided the strong party of raiders with the element of surprise, the ability to get through the wire, and continued close support for their attack. ${ }^{211}$ The raiders fought hard in the enemy trench and bombed the dugouts on their 150 yard-wide frontage. With the enemy dugouts full of soldiers, the German casualties were thought to be high, as raiders tossed grenades and Stokes demolition bombs into positions. Prisoner identification was obtained, and the official report believed that "considering the opposition met with, our casualties were slight.",212

\footnotetext{
${ }^{210}$ Cook, Shock Troops, 57.

${ }^{211}$ LAC, RG9, v.3858, 82/4, "Raids Carried Out By the Canadian Corps, October-December 1916, 'Nov.21,"” 4 January 191[7]. Note: The document had the date of 4 January 1916 on it, but that must have been a typo considering the dates of the raids it was discussing. January 1917 therefore seems much more likely. ${ }^{212}$ LAC, RG9, v.3858, 82/4, "Raids Carried Out By the Canadian Corps, October-December 1916, "Nov.21," 4 January 191[7].
} 
Not all raids that month provided fruitful intelligence information, despite being successfully carried out. This was demonstrated when the Canadians undertook two raids on the night of 27 November 1916 in the same general sector of Souchez. The $31^{\text {st }}$ Battalion attacked the trench system of M.32.c. $9^{1 / 2} \cdot 2^{1 / 2}$, just north of the town of Souchez, at 0330 with a small attack party of 14 raiders. ${ }^{213}$ Their aim was to inflict casualties and secure identification, and the raid was designed to take place very quickly, with only three minutes allotted for the raiders to carry out their objectives. ${ }^{214}$ At zero hour, the raiders attacked simultaneously with the commencement of the supporting artillery barrage. Private Donald Fraser of the $31^{\text {st }}$ Battalion recounted that "they made their way over the desolation of No Man's Land under [a] rifle grenade barrage. ${ }^{.215}$ A rifle grenade was a small artillery weapon that used the normal rifle to fire a modified grenade on a parabolic arch to the target. This gave the raiders increased medium-ranged forward firepower, with the grenade able to soar over 200 metres. Rifle grenade parties would soon become prevalent in supporting Canadian raids, as they offered powerful forward "artillery" to cover the raiders' assault and to destroy obstacles such as machine gun positions.

The $31^{\text {st }}$ Battalion's raiders attacked the German trenches and then split up into two groups, one going left and the other right. The left party continued through demolished trenches and found no Germans for 30 yards. ${ }^{216}$ The right party encountered a small garrison of five Germans, two of whom were killed while the other three withdrew. The raiders were going to get the bodies back for intelligence purposes, but owing to obstacles and wire they were forced to

\footnotetext{
${ }^{213}$ LAC, WD, $31^{\text {st }}$ Infantry Battalion, 27 November 1916.

${ }^{214}$ LAC, WD, $31^{\text {st }}$ Infantry Battalion, "T.N.85, $6^{\text {th }}$ Canadian Infantry Brigade," 25 December 1916.

${ }^{215}$ Fraser, The Journal of Private Fraser 1914-1918: Canadian Expeditionary Force. (Victoria: Sono Nis Press, 1985), 236. See also LAC, WD, $31^{\text {st }}$ Battalion, "Special Report on Raid," 27 November 1916, for details of the start of the raid.

${ }^{216}$ LAC, WD, $31^{\text {st }}$ Infantry Battalion, "Special Report on Raid,” 27 November, 1916.
} 
abandon their effort for fear of being held up and caught in their own barrage or a German counterattack. Therefore, the raid resulted in little useful intelligence for the effort, but several Germans were killed, enemy trenches were destroyed, and no Canadians were injured. ${ }^{217}$ This type of fighting alone would not bring the Allies victory on the Western Front, but raids gave psychological and instructional benefits to the men who carried them out, and provided them with an outlet for their frustration by allowing them to cross No Man's Land and attack the enemy.

The $8^{\text {th }}$ Battalion raided at the same time as the $31^{\text {st }}$ Battalion, but to the south of Souchez village. Its attack yielded a similar lack of clear-cut results. ${ }^{218}$ The first detachment of raiders found no Germans upon entering the trench, possibly due to the fact that they fled after working parties or patrols observed that their wire had been cut and knowing that a raid might soon follow that night. The other party attempted to enter the German lines, but met stiff resistance and uncut wire that forced their withdrawal, but only after one officer and five privates were killed, and an additional officer and 30 privates were wounded. ${ }^{219}$ No prisoners were secured, and further casualties were caused to the $8^{\text {th }}$ Battalion's men from German artillery retaliation. ${ }^{220}$ Both raids indicated that more lessons had to be processed, especially in clearing enemy barbed wire at the jumping off point of a raid without alerting the Germans to the possibility of a raid.

Yet despite these setbacks, there was an indication that the intense schedule of trench raids was beginning to tell on the enemy. Captain Maurice Pope of the $11^{\text {th }}$ Brigade Intelligence Staff remembered:

${ }^{217}$ LAC, RG9, v.3858, 82/4, "Raids Carried Out By the Canadian Corps, October-December 1916, 'Nov.21," 4 January 191[7].

${ }_{218}^{2}$ LAC, WD, $8^{\text {th }}$ Infantry Battalion, 27 November 1916.

${ }^{219}$ LAC, RG9, v.3858, 82/4, "Raids Carried Out By the Canadian Corps, October-December 1916, 'Nov.27,'” 4 January $191[7]$.

${ }^{220}$ LAC, WD, $8^{\text {th }}$ Infantry Battalion, 27 November 1916. 
The German Army will receive a tremendous hammering...and I very much doubt if they will have an appetite for any more. The end of the season should finish our heavy work. We are raising the devil with him these days and twenty four hours never pass that there is not a trench raid within actual sight. These, of course, are but forerunners of what is to come and they must trouble him a good deal. The Canadians are giving quite a lot of satisfaction with their successes in these minor operations. $^{221}$

Raids were being planned and executed with great regularity, and the lessons they were teaching about wire cutting, infiltration, attack doctrine, and other operational aspects would be very useful for future operations. In February 1917, a First Army dispatch containing "some of the points which have been brought most prominently to notice, and to which much of the success of the raids may be [ascribed]," outlined sixteen major areas where successful raids were providing lessons for battlefield tactics and doctrine that would be employed in future battles. ${ }^{222}$ The essential elements outlined in the report, for example, were exactly those which characterized the planning and preparation of the major battles. These included: reliable and complete information gathering; an emphasis on reconnaissance; the need for careful preparations; the emphasis on thorough training for all ranks; the preservation of the element of surprise, the effective cooperation with supporting elements such as artillery and machine guns; the need for the attacking infantry to closely follow the creeping barrage; and finally, the successful counterbattery work. ${ }^{223}$ These fundamental features would be the cornerstone of battle planning in 1917. Successful raids also had the ability to raise a unit's morale, as a raid that went smoothly and

\footnotetext{
${ }^{221}$ Maurice Pope, Letters from the Front. (Toronto: Pope \& Co., 1993), 78.

${ }^{222}$ LAC, RG9, v.4149, 15/11, "Some Notes on Raids," 20 March 1917. For smaller unit operations, see also LAC, RG9, v.4148, 14/8, dispatch " 3 rd Canadian Division, B.M.R. 510, Brigadier-General A.G. MacDonell, 7 " Infantry Brigade," 9 March 1917.

${ }^{223}$ LAC, RG9, v.4149, 15/11, “Some Notes on Raids, 'xvi,"” 20 March 1917.
} 
accomplished its objectives with the minimum of casualties provided the raiders with the satisfaction of having harassed the enemy, and perhaps moved a step in the right direction towards ending the war.

The month of December 1916 saw Canadian raiding intensify in frequency. On 9 December at 0440 , the $60^{\text {th }}$ Battalion raided at a trench point called Forges Sap, but were unable to penetrate the deep wire in front of the German position. ${ }^{224}$ This failure occurred despite using a 10-foot bangalore explosive on the area to be attacked. However, not enough wire was blown up, so the raiders resorted to throwing grenades at the German garrison and then retreating back to friendly lines. According to the war diary, the raiders inflicted casualties with their grenades, and experimented with the use of a more powerful thrown grenade in the improvised form of ammonal explosive in a large metal tin, but they had been unable to penetrate the enemy lines and had not completed their orders. ${ }^{225}$

Only an hour after the $60^{\text {th }}$ Battalion's raid began, the $3^{\text {rd }}$ Battalion raided to their north just outside of Souchez. Planning for the raid began on 30 November, with teams practicing on recreated trenches behind the lines that were made with the aid of reconnaissance plane photographs. Their training completed on 6 December, the raiders returned to the front lines to carry out their assault. ${ }^{226}$ Their 83 -strong twin-pronged attack entered the German trenches at two points simultaneously. According to the official report, "they found the trenches heavily manned and inflicted many casualties, among which [two] officers are claimed to have been killed. ${ }^{227}$ The entire raid took eight minutes to complete, in which time the raiders also cleared

\footnotetext{
${ }^{224}$ LAC, RG9, v.3858, 82/4, "Raids Carried Out By the Canadian Corps, October-December 1916, 'Dec. 9,"” 4 January 191[7].

${ }_{225}^{22}$ LAC, WD, 60 $60^{\text {th }}$ Infantry Battalion, 9 December 1916.

${ }^{226}$ LAC, WD, ${ }^{\text {rd }}$ Infantry Battalion, "Report on Minor Operation," 9 December 1916.

${ }^{227}$ Ibid.
} 
100 yards of enemy trench and destroyed 14 dugouts with large charges of gun cotton. ${ }^{228}$ The $3^{\text {rd }}$ Battalion raiders also captured an enemy machine gun, a significant prize of any raid because it deprived the Germans of that weapon, could have provided intelligence information, and served as a trophy to enhance battalion pride. To that end, the raid also apparently had a positive effect on the unit's morale. The raid "greatly increased the esprit de crop and [the entire] party [were] keen for another such operation." 229 Not only were the veteran raider's spirits raised, but the raid also served to instruct new recruits in the intricacies of trench warfare - in effect, "bloodying" these new men: " $70 \%$ of the personnel [were] composed of draft men who had never seen a fight before, and who now know from experience that they are superior to the enemy."230

\section{$5^{\text {th }}$ Battalion Balloon Trench Raid, 10 December 1916}

Raids in December 1916 demonstrated continued advancements in tactics and planning, especially the integration of small-unit tactics in conjunction with coordinated supporting elements in the assault. One raid in particular confirmed this evolution. Just a few hundred yards to the north of where the $43^{\text {rd }}$ Battalion raided, the $58^{\text {th }}$ Battalion undertook a medium sized raid on 10 December $1916{ }^{231}$ This raid was to be carried out on a section of enemy front line called Balloon Trench, and was intended to capture enemy prisoners for identification, inflict casualties to the enemy, and to destroy significant emplacements, trenches, and dugouts in the attacked area. ${ }^{232}$ These were standard goals of raids by the winter of 1916 , with additional objectives occasionally being tasked to the raiders only if special operational circumstances were present, such as the destruction of a specific enemy emplacement or the capture of particular information.

\footnotetext{
${ }^{228}$ LAC, WD, $3^{\text {rd }}$ Infantry Battalion, "Report on Minor Operation, Results of the Raid," 9 December 1916.

${ }^{229}$ Ibid.

${ }^{230}$ Ibid.

${ }^{231}$ LAC, WD, $58^{\text {th }}$ Infantry Battalion, 10 December 1916.

${ }^{232}$ Shackleton, 104.
} 
The artillery support for the raid was especially intricate, as Operation Order No. 6 for the $3^{\text {rd }}$ C.D.A. stipulated that three batteries, the $39^{\text {th }}$, the $36^{\text {th }}$, and the $30^{\text {th }}$, all contribute their firepower to the raid. Timings were exact, as barrages were set for specific grid references and ordered to lift to others at pre-arranged schedules and in 50 yard increments in order to create a box barrage with high explosive and shrapnel shells to protect the raiders from counterattacks. Later on, the barrage schedule would catch enemy reinforcements in the open with shrapnel shells. ${ }^{233}$ Additional support was arranged from trench mortars and 4.5-inch howitzer batteries. Communications with the artillery support were essential, so the instructions ordered that "Battery commanders will see by constant checking from 5PM onwards that telephone lines to Brigade are absolutely clear and in good working order."234 The operation order went on to specify that, "Battery commanders themselves...will be in direct communication with Brigade headquarters up to the moment of opening fire. Gun crews will be standing to ready to open fire on the word from 6.15PM...It is to be especially noted that as fire is not to commence at any prearranged time but on the word 'Fire' all guns must be on constant readiness." ${ }^{235}$ The raid's planners had made the important decision to link artillery and infantry, in order to protect the latter. The working out of this communications system, using signals of telephone and flares, would be critical in future set-piece battles where artillery played such vital roles in supporting the assault elements.

The raiders, numbering one officer and 40 other men, were split into six parties, each with specific tasks to be carried out during the raid. ${ }^{236}$ The individual parties, assigned a designated letter, were all led by a non-commissioned officer and numbered six to eight men.

\footnotetext{
${ }^{233}$ LAC, RG9, v.4149, 15/5, "Centre Group, 3 ${ }^{\text {rd }}$ C.D.A. Operation Order No.6," 9 December 1916.

${ }^{234}$ Ibid.

${ }^{235}$ Ibid.

${ }^{236}$ LAC, WD, $58^{\text {th }}$ Infantry Battalion, 10 December 1916.
} 
Party "I" was in charge of the bangalore explosive that would destroy the German wire and allow the assault parties to enter the trench. Following the opening in the wire, party " $G$ " would carry a bridge that would span the trench and allow the raiders to quickly storm the communications trenches beyond the front line trench. Once there, they would set up defensive bombing blocks to support parties "E," "F," and "H," while they stormed dugouts and searched for prisoners. Additional support parties, "A" and "B," would "carry a reserve supply of bombs, assist with wounded men and prisoners and, if necessary, cover the retirement of the Raiding Party."237 To assist and coordinate these specific combat parties was a dedicated signals section established at a crater near the point of attack to keep in constant contact via telephone and flares with artillery, trench mortar, machine gun support elements, and battalion headquarters. ${ }^{238}$

The attack, at the signal of the detonation of the bangalore explosive, initially went well. The parties stormed through the new gap in the German wire, and the signal section in the crater brought the supporting artillery bombardment to bear on the enemy reserve lines in the prearranged box barrage. ${ }^{239}$ Parties "I" and "J" attacked where they were supposed to, but the section of trench allocated to them turned out to be a "blind" trench full of thick wire and they were unable to go further. Being fired on by an enemy machine gun, these parties silenced it with grenades, but then, in the confusion, retired to their own lines after 15 minutes without notifying the remaining parties. ${ }^{240}$ This action would prove costly. The other parties were bombing dugouts and attacking down their pre-determined assault routes, meeting heavy resistance at times from grenade-throwing enemies. These grenade battles left several Canadians wounded, but the raiders continued with their assault. The senior officer, Lieutenant Shortt, was killed

\footnotetext{
${ }^{237}$ LAC, WD, $58^{\text {th }}$ Infantry Battalion, "Operation Order No. 34, 'Covering Party,"” 9 December 1916.

${ }^{238}$ LAC, WD, $58^{\text {th }}$ Infantry Battalion, 10 December 1916.

${ }^{239}$ LAC, RG9, v.4149, 15/5, despatch "To: $9^{\text {th }}$ Canadian Infantry Brigade, From A/O.C. $58^{\text {th }}$ Canadian Infantry Battalion," 11 December 1916.

${ }^{240}$ Shackleton, 107.
} 
trying to protect the flank of the attack, a task that was supposed to be fulfilled by the then retreated parties. ${ }^{241}$

After carrying out the attack, the rest of the raiders withdrew under the protection of their artillery and covering parties. Although dugouts were destroyed, machine guns put out of action, and many Germans presumed killed, the raid cost the Canadians as well. The raiders had suffered three missing, two of whom were dead, and nine wounded. No prisoners or identifications were secured either, for dugouts were destroyed before information could be taken. ${ }^{242}$ This raid demonstrated that, despite the advanced party system, and the intricate planning, there was bound to be confusion in enemy trenches, especially when attacking in the dark and facing resilient defenders. Even minor mistakes could result in major losses.

\section{The Raider's Arsenal: Explosives}

As demonstrated by the $58^{\text {th }}$ Battalion's attack on 10 December, trench raids were violent affairs, and all manner of deadly offensive weaponry was utilized by Canadian raiders to destroy, maim, and kill. Grenades were one of the most effective weapons, and became an essential piece of the trench raider's offensive arsenal. The outstanding success of the grenade in raids played a major role in its adoption as a vital technological component in subsequent battles. By mid 1916, Canadian units began to specialize in bombing, and devoted training syllabi to their specialized use in conjunction with infantry assaults. ${ }^{243}$ Many units, British or Dominion, could point to the grenade as an agent of success on the battlefield. But the grenade could also lead to stalled

\footnotetext{
${ }^{241}$ Shackleton, 108.

${ }^{242}$ LAC, RG9, v.4149, 15/5, despatch "To: $9^{\text {th }}$ Canadian Infantry Brigade, From A/O.C. $58^{\text {th }}$ Canadian Infantry Battalion," 11 December 1916.

${ }^{243}$ Rawling, Surviving, 72.
} 
attacks, for only a limited number could be carried, and when they were used the attackers often were unable to push forward. ${ }^{244}$

As in major operations, grenades were central to the raid and the depletion of a soldier's grenade supply meant that further advances in the enemy trench would be much more difficult. Donald Fraser, a private of the $31^{\text {st }}$ Battalion, recounted an episode where during one raid, "the supply of bombs being exhausted, our men retired. Our casualties were fifteen wounded. The enemy was supposed to have fifty casualties...we found Fritz alert and too strong so [we] had to retire." 245 Major-General Arthur Currie of the $1^{\text {st }}$ Division, later to command the Canadian Corps, stressed in October 1916 the importance of grenades and the need to train the men to using both Canadian and German grenades, which would be employed when the Canadians had exhausted their own supply. ${ }^{246}$ The grenade was an area-effect weapon that could injure all within a few yards radius, or cause wider damage over open space. This could lead to friendly fire in the chaotic trench battles. Some battalion orders even stressed "the danger to every man will be increased by a free use of the bomb," and therefore ordered that they only be used in the clearing of strongpoints and dugouts. ${ }^{247}$

An extension of the hand-thrown grenade was the rifle-fired grenade. As mentioned earlier, this weapon was a grenade that could be fired out of the barrel of a standard rifle, crucially increasing its range and effective killing potential. These projectile explosives, especially when fired in volley, were a very effective weapon to combat enemy strongpoints,

\footnotetext{
244 Ibid.

245 Fraser, 183.

${ }^{246}$ Rawling, Surviving, 82.

${ }^{247}$ LAC, WD, $28^{\text {th }}$ Infantry Battalion, Instructions for a Minor Operation, 1 May 1918.
} 
pockets of resistance, or to provide a form of mobile artillery bombardment. ${ }^{248}$ Private John Becker of the $75^{\text {th }}$ Battalion described the procedure of firing a rifle grenade:

We used both the Mills bomb and the Hales Grenade, the former being on a time fuse detonator and the latter a percussion cap. Steel rods were screwed into the base of the bomb, then the rod stuck down in the mouth of the rifle barrel. A blank cartridge was put in the breach, the butt of the rifle braced against the ground, and with the rifle held at an angle. The trigger is pulled... We became very proficient at this method of warfare. ${ }^{249}$

Rifle grenades quickly became a favourite forward artillery weapon of the Canadians during raids. When the $49^{\text {th }}$ Battalion raided on 28 January 1917 , their success was mostly attributed to the accurate artillery support from squads of rifle grenadiers. Major R.H. Palmer, commander of the raid, extolled the weapon, remarking "it was exactly what was required." 250 Another example of the use of rifle grenades in Canadian raiding occurred on 4 February 1917 when the $73^{\text {rd }}$ Battalion raided Love Crater and used them as part of a covering party for the assault grenadiers. ${ }^{251}$ The rifle-grenadiers proved very effective at silencing pockets of resistance from machine guns and enemy grenade posts, as was experienced by " $\mathrm{A}$ " party when it was attacked by German grenadiers. The report stated that "some opposition was met with, about [six] of the enemy endeavouring to hold the trench by throwing stick bombs; these were dispersed by rifle grenadiers." ${ }^{252}$ As a form of forward artillery support, the raiders were able to use these weapons to engage and destroy enemy pockets of resistance at range, which enabled the raiders to attack

\footnotetext{
${ }^{248}$ Rawling, Surviving, 50.

${ }^{249}$ Becker, 84-85.

${ }^{250}$ LAC, WD, $49^{\text {th }}$ Infantry Battalion, "Report on Minor Operation, Our Artillery, Remarks," 29 January 1917.

${ }^{251}$ LAC, Rg9, v.3858, 82/6, "Report on Raid Carried Out by $73^{\text {rd }}$ Canadian Infantry Brigade," February 1917.

${ }^{252}$ LAC, Rg9, v.3858, 82/6, "Report on Raid Carried Out by $73^{\text {rd }}$ Canadian Infantry Brigade, 'Stories of the various parties," February 1917.
} 
from the safety of cover. However, not all troops saw the rifle grenade as a positive weapon, and some even thought it dangerous. Charles Savage, a sergeant of the $5^{\text {th }}$ C.M.R., noted that "Rifle grenades were not particularly popular...for quite often they exploded at the moment of firing instead of waiting in a well-behaved way until they reached the German line."253 Despite the danger to the users of this innovative technology, rifle grenades eventually became a staple weapon in the infantry arsenal.

Raiders not only used explosives to kill and maim the enemy, but also to breach the enemy's barbed wire to allow the raiders to storm the trenches. The bangalore ammonal tube was the most popular of these devices. This tube of explosives would be inserted under the enemy wire and detonated, clearing a path for the raiders to assault. They were popular in stealth raids for they were an effective way to clear wire without alerting the Germans to an impending raid via preparatory wire-cutting artillery and trench mortar bombardments. However, bangalores were cumbersome to carry while on a stealth raid and, as seen above, were not always reliable to detonate when triggered. In an early test of the bangalores by the $28^{\text {th }}$ Battalion in January 1916 , they experimented with three types of the explosive device: one was made using biscuit tins and filled with guncotton; another was made using soldered ammonal tubes and filled with ammonal explosive; and a third was made of iron with ammonal explosive. ${ }^{254}$ After all three were thoroughly tested, the conclusion was that the ammonal explosive was superior to guncotton by a large degree, and that the iron tubing was too heavy and cumbersome to be carried on a raid, despite its superior explosive force. This method of clearing wire was deemed excellent, for "The

\footnotetext{
${ }^{253}$ CLIP, Charles Henry Savage, memoir, March 1916.

${ }^{254}$ LAC, RG9, v.4140, 11/6, "Destruction of Wire Entanglements, 'The torpedoes,'” 13 January 1916.
} 
debris caused by the explosion tended to fly out radially [sic] from the pipe, and hence would do little harm to attacking party lying out ready to assault.,"255

In another case, scouts from the $25^{\text {th }}$ Battalion, in observing the effects of one of the early bangalores in a raid carried out by their battalion on 1 March 1916, reported that "In every spot in the enemy wire reached by patrols it was out and smashed, and no difficulty would be had in getting through...At [the] corner of [the] salient, [the] torpedo was placed under knife rests; wood and wire was all cut and levelled, and a space wide enough to allow 12 men to walk abreast made. ${ }^{, 256}$ What this bangalore report also demonstrates was the communication of new experiments and lessons learned throughout the C.E.F., so that tactics and technology were to be improved in all the Canadian raids. This report was sent up the chain of command to the $1^{\text {st }}$ Division headquarters from the $25^{\text {th }}$ Battalion, who then redistributed it down to all infantry, engineer, and artillery formations. ${ }^{257}$ Lessons were being learned, experiments analysed, and the results were being circulated to those parties who could make the best use of them.

Other experimental weapons proved less useful in raids. One demonstration by the $10^{\text {th }}$ Battalion on 1 March 1916 was a perfect example of experimentation with unconventional weaponry in an effort to find better ways of assaulting German trenches. The raid was a dummy attack, where the primary goal was to goad the enemy into retaliating to a feint against their lines in order to discover information about their sentry systems, level of support from rear units, and the strength of their garrisons. The attack was also planned to explore new weapons and tactics: to discover new ways of cutting enemy barbed wire; to explode a great number of smoke bombs 50 yards in front of the $10^{\text {th }}$ Battalion's listening posts to ascertain their usefulness in screening a potential assault; to do an early test of rifle grenades as a forward artillery weapon; to throw

${ }^{255}$ LAC, RG9, v.4140, 11/6, "Destruction of Wire Entanglements, "Conclusion," 13 January 1916.

${ }^{256}$ LAC, RG9, v.4053, 24/4, "Bangalore Torpedoes," 5 March 1916.

${ }^{257}$ Ibid. 
grenades by a catapult device into the German trenches; to float a small raft full of explosive and smoke bombs along the River Douve to be exploded remotely once it reached German lines; and finally, to pour sixteen gallons of gasoline into the river and then ignite it. ${ }^{258}$ The incorporation of these tactical experiments all at once revealed the experimental nature of the raid as a laboratory to test new tools of battle.

The operation was a mixed success and the final report indicated that the Germans were not alerted to the attack despite a heavy bombardment, and that their lines were not held in strength. ${ }^{259}$ Canadians also found that the grenade catapults were a complete failure, as both of the machines immediately broke, while the raft did nothing more than create a loud explosion. Furthermore, the smoke bombs were ineffective in providing a visible screen in order to hide friendly movement without being spotted by the enemy. ${ }^{260}$ Despite the failure of many weapons, the Canadians were experimenting on the battlefield, and if it had not been for raids there would have been very few opportunities to hone tactics and integrate them with new weaponry for their use in the large set-piece battles. Moreover, these new weapons constantly faced resistance by conservative notions of battle-craft within the Allied command. Historian Paddy Griffith confirms the difficulties in the experimentation of weaponry within the BEF, citing "The integration of each new weapon into the infantry's battle was almost always a long and difficult institutional undertaking, fraught with arguments and administrative nonsense of every sort.,261 He argues that specialist weapons, such as grenades and rifle-grenades, would take time to be fully integrated into the assault tactics of the BEF, with grenadiers being given their own "monastic order" and segmented until their eventual formal integration with the average riflemen

\footnotetext{
${ }^{258}$ LAC, RG9, v.3858, 84-11, "Report on Demonstration by 10 $0^{\text {th }}$ Canadian Battalion," 3 March 1916.

259 Ibid.

${ }^{260}$ LAC, RG9, v.3858, 84-11, "Report on Demonstration by $10^{\text {th }}$ Canadian Battalion, 'Deductions,"” 3 March 1916.

${ }^{261}$ Griffith, 198.
} 
in February $1917 .^{262}$ However, at least the use of these weapons in successful operations like raids assisted the case for those in favour of the proliferation and integration of these weapons into the infantryman's arsenal. It was in raids where these weapon systems were being experimented, honed, and eventually integrated into evolving attack tactical doctrine.

\section{$1^{\text {st }}$ C.M.R. Battalion Lille Road Raid, 20 December 1916}

Trench raiding had become firmly established in the Canadian battle doctrine by December 1916. In the midst of the partial successes and failures of that month, one raid stood out as an indication of the continually evolving tactical learning curve. The $3^{\text {rd }}$ Battalion's failed raid on 9 December 1916 was compensated for by the wildly successful and innovative raid pulled off by the $1^{\text {st }}$ C.M.R. Battalion on 20 December at a point called Lille Road, which was situated south of the town of Souchez. ${ }^{263}$ Lieutenant-General Sir Julian Byng, commander of the Canadian Corps, had ordered a large assault to penetrate deeply into enemy lines. It was also to be carried out in daylight, which would surprise the enemy but might also leave the attackers vulnerable. ${ }^{264}$ This raid was on a very large scale, with 12 officers and 410 other men assigned to the various assault parties. With heavy artillery and trench mortar support, the raiders attacked and penetrated not only the front line trenches, but their support and secondary trenches as well. ${ }^{265}$ This operation demonstrated two very important facets of the continual evolution of Canadian raiding. First, it revealed that the impetus of minor operations was by this time transferred from the lower echelons of command to the higher levels of command, reaching all the way up to the Corps Commander. Second, the fact that the raid was ordered on such a large scale, was to take place in daylight, and was charged with penetrating the enemy lines so deeply

\footnotetext{
${ }^{262}$ Ibid, 199.

${ }^{263}$ LAC, WD, $1^{\text {st }}$ C.M.R., 20 December 1916.

${ }^{264}$ LAC, RG9, v.3858, 83/2, "Extract from Report of G.O.C. $3^{\text {rd }}$ Canadian Division on Minor Operation Carried out by the $8^{\text {th }}$ Canadian Infantry Brigade," 2 January 1917.

${ }^{265}$ LAC, RG9, v.3858, 82/4, "Raids Carried Out By the Canadian Corps, Dec 20 1916," 4 January 191[7].
} 
shows that the Canadian high command was attempting to push the envelope on raiding, making these operations more and more intricate and daring. This raid was, in essence, a miniature battle. Raids like this revealed the bleeding of these minor "battles" into major set-piece attacks, as the operational preparation and battle-planning were nearly identical to a conventional battle, if only on a smaller scale.

The large daylight raid would have to overcome all enemy resistance, thoroughly search and destroy dugouts and emplacements, and defend against counterattacks. ${ }^{266}$ It was decided that the assault on the 800 yard frontage would be carried out by two battalions, one primary attacking battalion and one providing support through a "feint attack," in order to draw away reinforcements from the main assault. ${ }^{267}$ The infiltration of the vast number of trench raiders was expedited by many craters and saps that were to be used for the jumping off points of the raiders, and also the use of "three shallow mine galleries were especially prepared and used in which to assemble the assaulting troops during the intensive bombardment. ${ }^{268}$ These galleries were very reminiscent of those that would be used in the assault on Vimy Ridge in April 1917.

The ground was very carefully chosen, and detailed instructions were given as to the occupation and withdrawal of the raiders. It was decided that a withdrawal during daylight would have proven costly, as would one during night over unfamiliar ground. Therefore, the raiders were detailed to withdraw in twilight, just before it became dark, meaning the raiders would be in the enemy trenches for nearly two hours. ${ }^{269}$ This was a radical change, as raids were meant to be rapid "dash and destroy" operations, but this new tactic argued for a longer occupation. The primary attacking parties were detailed in three "waves," with each successive wave tasked with

\footnotetext{
${ }^{266}$ LAC, RG9, v.4106, 22/15, "Report on Minor Operation, December 20", 1916 ," 29 December 1916.

${ }^{267}$ Ibid.

${ }^{268}$ LAC, RG9, v.3858, 82/4, "Raids Carried Out By the Canadian Corps, Dec 20 1916," 4 January 191[7].

${ }^{269}$ Ibid.
} 
"leapfrogging" over the last. The first wave consisted of the main attack force, suitably equipped with rifles, pistols, and grenades. The second wave included Lewis Gunners and riflemen to further the attack and support the first wave with heavier firepower. The third wave, or "moppers up," would advance through the other two to reach the final objective. A further support party was kept in reserve to assist the others in fighting off counterattacks. ${ }^{270}$ This tactic, first experimented with in raids, anticipated the infantry doctrine that the Canadians would successfully use at the Battle of Vimy Ridge and other subsequent major battles in 1917 and 1918, demonstrating the role of raids as the laboratory for new innovations in battlefield operations.

Immense planning and training went into the raid, as the different parties all worked on scale-models of the assault ground and participated in practice assaults over a full-scale taped model of the battleground for nearly a month in advance of the attack. ${ }^{271}$ Each man was trained according to his specific task, and all attended special instruction at the Brigade Bombing School. Special luminescent tape was to be laid in No Man's Land to guide back the raiders as it became dusk, and all arms of the assault were linked thorough communications between their forward H.Q. and their fighting elements. ${ }^{272}$

With the length of preparation and the weight of firepower devoted to the task, the attack went extremely well. At 1300 the assaulting parties safely reached their jumping off points undetected. The artillery bombardment commenced at 1330 , and then by 1500 the raiders advanced behind their accurate and timely creeping barrage. ${ }^{273}$ The raiders crashed into the enemy lines at 1518 and bombed dugouts and enemy emplacements while fighting off German

\footnotetext{
${ }^{270}$ Ibid.

${ }^{271}$ LAC, WD, $1^{\text {st }}$ C.M.R., December $1^{\text {st }}, 1916$.

${ }^{272}$ LAC, RG9, v.4106, 22/15, "Report on Minor Operation, December 20"th 1916 ," 29 December 1916.

273 Ibid.
} 
counterattacks. The German retaliation was slow to respond, because according to captured prisoners there was confusion in S.O.S. signals. ${ }^{274}$ The raid was so successful that after 35 minutes the attack area had been consolidated: all enemy soldiers were killed or taken prisoner, and all dugouts and emplacements were destroyed. The operation report noted that the assaulting parties could have exercised more caution and patience, for valuable information and prisoners were simply bombed into oblivion by demolition charges as the excited Canadian raiders forged their way deeper into the German lines. ${ }^{275}$ The raiders dug in and waited until it was time for the withdrawal, and it was during this period that they took the majority of their casualties from enemy shellfire. ${ }^{276}$ Despite these minor criticisms, the raid was deemed a success. The raiders withdrew on schedule at 1645 with 53 casualties: eight killed and 45 wounded. ${ }^{277}$ Considering the number of raiders employed and the resistance they encountered, the losses to the Canadians seemed extremely low and was an indication of the thoroughness of the training and preparation put into the assault. Having said that, as in previous raids, it was very difficult to ascertain the casualties inflicted on the enemy.

The $1^{\text {st }}$ C.M.R. was supported by a secondary "dummy raid" by the $4^{\text {th }}$ C.M.R. of 74 men designed to cover the withdrawal of the main raid. They did not succeed in penetrating the German trench line, but they were only tasked with diverting enemy attention away from the primary attack. In this they succeeded, perhaps too much so, for they drew a very heavy bombardment when they were attempting to reach their jumping off point and suffered a number of casualties. The enemy was alert and swept the area with machine gun fire in conjunction with

\footnotetext{
${ }^{274}$ LAC, RG9, v.3858, 82/4, "Raids Carried Out By the Canadian Corps, Dec 20 1916," 4 January 191[7].

${ }^{275}$ LAC, RG9, v.4106, 22/15, "Report on Minor Operation, December 20 ${ }^{\text {th }}, 1916$," 29 December 1916.

${ }^{276}$ Ibid.

${ }^{277}$ LAC, RG9, v.3858, 82/4, "Raids Carried Out By the Canadian Corps, Dec 20 1916," 4 January 191[7].
} 
the artillery shells, and it was evident that they were expecting an attack where their wire had been previously cut. ${ }^{278}$

Occasionally called "demonstrations," dummy raids were tools for harassing German garrisons and of causing unease amongst their sentries in order to soften up the area for a "hard" raid later on in the tour. Dummy raids attempted to goad the enemy into revealing their positions and to man their parapets in order to expose their infantry to a pre-arranged artillery bombardment. In doing this, dummy raids also served an intelligence gathering role. In August 1916, Corps Commander Sir Julian Byng explained to three of his divisions that he was "of opinion that loss might be caused to the enemy by organizing dummy raids with the object of getting him to man his trenches and give a target for our artillery." ${ }^{279}$ This tactic fit into General Haig's idea of attrition of the enemy forces without much risk to his own forces. General Byng's suggestions were heeded, and a few days later on 16 August 1916 , the $19^{\text {th }}$ Battalion attempted one such dummy raid on a point called Hollandscheschuur Farm. ${ }^{280}$ Instead of launching grenades, the scouts of the battalion attached wires to the enemy barbed wire, and at 0345 shook them violently. According to Lieutenant-General Percy Radcliffe's report, the result was that the Germans "immediately commenced to bomb his own entanglement along the entire front...our artillery and Stokes Guns opened fire on selected targets on the enemy's front and support trenches...It appeared that in addition to the accurate fire of our artillery, the enemy's own guns must have done considerable damage and probably caused him some casualties."281 Such dummy raids were frequently used by the Canadians as means of distracting the enemy, gathering

\footnotetext{
278 Ibid.

${ }^{279}$ RG9, v.3858, 82/3, despatch "Canadian Corps, G. 784, $2^{\text {nd }}$ August 1916," 2 August 1916.

${ }^{280}$ LAC, RG9, v.3858, 82/3, "19 $9^{\text {th }}$ Battalion Operation Order 'X,", 16 August 1916.

${ }^{281}$ LAC, RG9, v.3858, 82/3, Lieutenant-General Radcliffe report, "Second Army, G. $17718^{\text {th }}$ Aug. 1916," 18 August 1916.
} 
information, but causing the Germans unease and constant annoyance with the aim of attriting their morale.

In an after-action report of the Lille Road raid, it was stipulated that the operation was a complete success and also provided useful lessons for future raid planning. Moreover, this raid anticipated, in all but scale, the planning, preparation, and operational outlay of major battles such as Vimy Ridge. The report stated that "wire cutting in broken ground is necessarily very difficult, but broken ground allows of close inspection of the wire, this inspection should be done by daylight." 282 It also suggested that "in the broken ground full of craters troops can be assembled well forward. I think this may be made us of for larger operations, in conjunction with Tunnels." 283 These lessons were vital, as they indicated key aspects of preparation for assaults and the easing or elimination of traversing No Man's Land. To close the distance with the enemy was essential, and this method of pushing soldiers forward, as honed in this raid and others that would follow, was a critical step in taking control of the battlefield. The attack on Vimy Ridge incorporated these assessments to great effect four months later in April 1917.

\section{Raiding Evaluated}

Early in 1917, the Canadian high command took stock of the operations reports and the lessons they provided from the raids carried out in the previous year. What they concluded was that there were many areas of raids that needed improving, including preparation, planning, and execution. Barbed wire continued to be an obstacle to the success of many raids. Artillery was still not as yet capable of destroying wire with any degree of efficiency due to scarcity of the new sensitive "Number 106" fuses on the shells, with the older fuses burying themselves into the ground before exploding, greatly diminishing their usefulness at wire cutting. The alternative

\footnotetext{
${ }^{282}$ LAC, RG9, v.3858, 83/2, "Extract from Report of G.O.C. $3^{\text {rd }}$ Canadian Division on Minor Operation Carried out by the $8^{\text {th }}$ Canadian Infantry Brigade," 2 January 1917.

${ }^{283}$ Ibid.
} 
was to employ scouts to cut the wire, but not all raids could deploy them for several nights in No Man's Land to cut the wire by hand, which could then be discovered during the day by alert sentries. Solutions to all of these problems, however, had been tried on the battlefield. ${ }^{284}$

The $18^{\text {th }}$ Battalion raid on 29 December 1916 exemplified the problem of wire cutting, for when it attacked the Southern Crassier in the Souchez sector, after first setting off a mine in the area, raiders were left to assault an abandoned trench. The German garrison, after noticing cut wire the day before and believing an attack was imminent, pulled back from the front lines. ${ }^{285}$ Lieutenant James Pedley of the $4^{\text {th }}$ Battalion recollected another time when wire cutting spoilt the success of a raid: "Good twenty yards forward of his covering party we see Dad...blaspheming as he strides along...Yet he is not fired on, though he must be well night twothirds of the way across to Fritz." Lieutenant Pedley continued to explain the reason for this strange occurrence, because "Fritz must have known by the artillery preparation...that this raid was on the ticket. He had withdrawn his men from the sector for a few hours, and only sent them back when the danger was over. ${ }^{, 286}$ Raids that ended up attacking abandoned positions were understandably wasteful enterprises. A proposed solution to the problem was to make several gaps in the German barbed wire in various places along the sector, with the aim of confusing the Germans about where the attack would actually be made.

Using artillery for cutting wire in preparation for a raid presented other problems, as Private Donald Fraser of the $31^{\text {st }}$ Battalion discovered: "I was badly disappointed when he mentioned that the artillery would be employed to break up the enemy wire...making use of the artillery meant advertising the raid to the enemy and allowing him to prepare plans to counter

\footnotetext{
${ }^{284}$ LAC, RG9, v.3858, 82/4, "Raids Carried Out By the Canadian Corps, October-December 1916, 'Points to be Noted," 4 January 191[7].

${ }^{285}$ LAC, RG9, v.3858, 82/4, "Raids Carried Out By the Canadian Corps, October-December 1916, 'Oct. 29,'” 4 January 191[7].

${ }^{286}$ Pedley, 261.
} 
it...I declined to participate...as it spelt absolute failure. ${ }^{, 287} \mathrm{He}$ had been correct in his assessment, as was evident when he continued to describe the results of the raid: "Heiny shot up his flarelights [sic] along two or three hundred yards of his front and I could see several of our men scurrying back, bent double. It was seen at once that the raid was a fiasco." The Germans were aware of the raid, and had apparently planned an ambush for the raiders because "when about twenty yards from the enemy wire, a German sentry called out... 'Here they are, about twenty of them.' A second later and seven or eight bombs were thrown in our midst...Fritz was prepared and waiting for the raid...There was absolutely no doubt but that the preliminary artillery fire gave the cue to what was to follow with ignominious failure for us. ${ }^{288}$ Wire cutting was never accomplished without endangering the mission, but through a trial and error process the infantry found options that worked for them.

Communication during the start of a raid was another area that was constantly investigated, because so many operations failed or faltered due to of the difficulty of coordinating attacks or other arms of the service. Suggestions were made to improve communications between infiltrating raiders and their support elements, such as having a support party with a telephone accompany the raiders in No Man's Land, which was one of the most reliable forms of communication available provided the lines were not cut by enemy fire. ${ }^{289}$

Weaponry selection was also found to have posed problems for the raiders. Grenades and explosives were favourite weapons for clearing trenches, destroying dugouts, and assaulting emplacements. However, explosives launched into a German dugout generally ruined vital intelligence, with one Canadian report observing that "a Company H.Q. dug-out was destroyed

\footnotetext{
${ }^{287}$ Fraser, 185.

${ }^{288}$ Ibid, 187.

${ }^{289}$ LAC, RG9, v.3858, 82/4, "Raids Carried Out By the Canadian Corps, October-December 1916, 'Points to be Noted," 4 January 191[7].
} 
after the Company Commander and 3 Telephonists had been made prisoners. Prisoners stated that there was a German Slide-rule Code in this dug-out...,290 But it was hard to restrain solders fighting for their lives, and harder still to convince them that they should somehow refrain from using the best weapons available to them. ${ }^{291}$

Finally, high command stressed in its report the importance of stealth raids, such as that which was undertaken by the $42^{\text {nd }}$ Battalion on the night of 26 December 1916. On this night, eight raiders infiltrated the German lines at Common Sap by manually cutting through the thick barbed wire, where they proceeded to ambush and capture two German sentries. The raiders then withdrew back to their own lines with their identifications and prisoner objectives met. ${ }^{292}$ The high command report noted that these stealth raids "seemed to be especially adapted for the purpose of getting identifications... With skilful scouting and resourceful officers and men, they should produce excellent results with very few casualties. ${ }^{293}$ The only drawback was that for stealth raids to work they had to be relatively small, and therefore were not ideal for destroying enemy trench systems or physically attriting enemy forces.

Throughout the post-Somme raids, Canadian Corps headquarters, in conjunction with other British formations, was studying the lessons of the battlefield, and particularly how and why raids succeeded or failed. They continually sought to improve all operational phases, from planning and training to logistics and small-unit tactics, in order to make raids as cost effective as possible. At lower level formations, the planning, coordination, and execution of raids among

\footnotetext{
${ }^{290}$ LAC, RG9, v.3858, 82/4, "Raids Carried Out By the Canadian Corps, October-December 1916, 'Points to be Noted," 4 January 191[7].

${ }^{291}$ Rawling, Surviving, 103.

${ }^{292}$ LAC, RG9, v.3858, 82/4, "Raids Carried Out By the Canadian Corps, October-December 1916," 4 January $191[7]$.

${ }^{293}$ Ibid.
} 
different fighting arms helped to hone an efficient, and improving, attack doctrine, which would be employed by those same formations in the larger set-piece battles.

\section{Raiding Lessons Forged into Doctrine}

In January 1917, Canadian Corps headquarters, in an attempt to improve attack doctrine by applying the lessons from raiding, drew up a thorough checklist so raids could be planned meticulously, efficiently, and in order to minimize the chance of failure. This doctrinal document was proof that raiding had become institutionalized throughout the Corps. The checklist aimed to provide junior commanders, who were tasked with organizing and planning a raid, once it had been ordered from the divisional or brigade level, with ample guidelines for raid preparation and execution forged from experience gained since late $1915 .^{294}$

The first stage of planning required that the officer in command of the raid select a precise objective, including target frontage, and to consider any special orders to be carried out, such as specific intelligence objectives or the procurement of a prisoner for identification. Second, the leader of the raid was to gather precise intelligence from scouts and patrols on the proposed site of attack. The officer would then map out scouting and attack routes, fields of enemy machine gun fire, and any other details of the attack or withdraw, in terms of terrain. Third, the officer was to have a meeting with all officers, or NCOs, who were in command of the specialized groups involved in the attack, where they would discuss the best methods of executing the raid. Fourth, the raid leader would draw up preliminary orders and start the preparation and training of the specialist groups. This would also include the commencement of patrols and wire-cutting artillery bombardments. ${ }^{295}$ Finally, the officer would draw up final orders for all commands involved with precise objectives, terrain details, enemy disposition, attack vectors, artillery

${ }^{294}$ LAC, RG9, v.4209, 1/12, “Detailed Sequence for Raid Preparation," January 1917.

${ }^{295}$ Ibid. 
timetables, and S.O.S. codes. ${ }^{296}$ This important document codified rules and approaches, and these once informal undertakings were now more likely to bleed into the planning for large-scale offensives such as Vimy Ridge, where many of these intelligence, preparatory, and coordinated approaches were mirrored on a macro-scale. It was during the five months of raiding before the April 1917 Battle of Vimy Ridge when the Canadian Corps was able to test and refine offensive doctrine, small-squad tactics, communications, and combined-arms assaults.

These lessons were also circulating throughout the larger BEF, as indicated by a 28 February despatch by First Army which stated: "the Army Commander wishes to impress on Corps Commanders the importance of special activity on the whole of the Army front, with a view of discovering any indication of withdrawal of the part of the enemy. Raids will furnish the best means of securing prisoners, and therefore, information; if the raids find the enemy's trenches and there are signs of withdrawal, every effort will be made to regain touch."297 Byng took the order and added a personal note to his junior officers: "The Corps Commander is confident that all divisions of the Canadian Corps will make it their business to get the earliest possible information of any withdrawal on the part of the enemy." ${ }^{298}$ Raids had become part of the established doctrine and war-fighting among BEF units on the Western Front.

The junior leaders seemed to respond positively to these systematized and standardized raids. Charles Henry Savage, a sergeant of the $5^{\text {th }}$ C.M.R., wrote that "making raids had become a real science and large ones...were very carefully planned. Besides having officers and men out for weeks practicing on dummy trenches, every precaution was taken to avoid confusion in No

\footnotetext{
${ }^{296}$ Rawling, Surviving, 104, and LAC, RG9, v.4209, 1/12, "Detailed Sequence for Raid Preparation," January 1917.

${ }^{297}$ LAC, RG9, v.3858, 82/6, dispatch "Canadian Corps, First Army No.G.S.516/37(a)," 23 February 1917.

${ }^{298}$ Ibid.
} 
Man's Land." ${ }^{299}$ From the $4^{\text {th }}$ Battalion, Lieutenant James Pedley remembered the excitement in the extensive preparation for an upcoming raid:

the whole battalion keyed up as never before in my time...rushing around establishing a signal post here, a message relay post there, a cage for detaining prisoners, a medical aid post...men are studying sketches made from the map and planning how they will use the brief twenty minutes allotted for their exploration of the German trenches before the deadly curtain barrage closes down again and forces them back into our lines...the colonel constantly on the wire to brigade, and everlastingly consulting with his own officers and in liaison with the artillery and Stokes mortars, settling barrage details. ${ }^{300}$

The increased tempo of raiding in the post-Somme era posed some problems. Although frequent raiding allowed the Canadians to hone their attack doctrine, junior officers were increasingly pressured by the high command, either at brigade, division, or corps level, to pull off more and more raids with limited time to plan and prepare operations. The $31^{\text {st }}$ Battalion's raid on Thelus on 29 March 1917 aptly demonstrates the problem of frequent and ill-prepared raids. Orders called for a pincer attack, with two parties advancing slightly apart and working toward each other. This was not a unique tactic, but it was contingent on both parties keeping pace with one another. "Luck did not favour the right party which suffered rather heavily," reported Lieutenant-Colonel A.H. Bell. ${ }^{301}$ This attacking party was assailed by German grenadiers, suffering delays and casualties. As well, Bell mentioned that "the groups moving northward had great difficulty in recognizing their positions in the trenches," resulting in the

\footnotetext{
${ }^{299}$ CLIP, Charles Henry Savage, memoir, 1917.

${ }^{300}$ Pedley, 259.

${ }^{301}$ LAC, WD $31^{\text {st }}$ Infantry Battalion, Operations Report, 30 March 1917.
} 
raiders being ambushed by German rifle-grenadiers and suffering further casualties. ${ }^{302}$ According to Bell, "Major Seaton had a difficult task in the preparation of the scheme on short notice and carrying it out without opportunity for practice, and with troops new in the locality." ${ }^{303}$ The lack of time for preparation and training led to increased instances of mistakes, confusion, and dead soldiers.

\section{The "Million Dollar Scrap:" $20^{\text {th }} / 21^{\text {st }}$ Battalion Calonne Trench Raid, 17 January 1917}

While raids became more frequent in the winter of 1916-1917, they were far from uniform. The terrain and enemy positions often dictated the nature of a raid. An operation that was geared to gathering intelligence was different than one that aimed to inflict mayhem on the enemy. The size of raids also varied, ranging from a mere handful of men to well over a thousand. Alfred Andrews, a captain from $2^{\text {nd }}$ Battalion and veteran from the First Contingent, wrote of a daring raid in 1917: "On March 14 Fitzroy and Templeman tried a one man raid. They got into a German front line and cleaned out a post but had to get out quick... It was an unofficial raid that couldn't be reported. Fitzroy knew no fear..." ${ }^{304}$ On 1 January 1917, the $42^{\text {nd }}$ Battalion launched a nine man stealth raid, while on the $17^{\text {th }}$ of the same month the $20^{\text {th }}$ and $21^{\text {st }}$ Battalions launched a monstrous operation that totalled 875 men. ${ }^{305}$ This raid was the famous "million dollar scrap," in reference to the estimated monetary value of the ammunition expended in the supporting artillery barrage. ${ }^{306}$

The Calonne trench raid was essentially a small battle, much like the previous pioneering Lille Road raid carried out by the $1^{\text {st }}$ C.M.R. in December 1916 . While the $1^{\text {st }}$ C.M.R. was executing their attack, the $20^{\text {th }}$ and $21^{\text {st }}$ Battalions were practicing for their own enterprise on

\footnotetext{
${ }^{302}$ Ibid.

${ }^{303}$ Ibid.

${ }^{304}$ CLIP, A.H.J Andrews diary, March 14, 1917.

${ }^{305}$ Rawling, Surviving 102.

${ }^{306}$ Cook, Shock Troops, 58.
} 
recreated trench systems behind the front lines. ${ }^{307}$ The 875 men were organized into five companies, each of which was divided into four platoons, with added sappers' companies attached. ${ }^{308}$ As was standard practice by this time, the men chosen for the raid were segregated from the monotony of trench routine, and spent intensive periods patrolling No Man's Land in order to familiarize themselves with the battle-space. They also spent weeks on course in reserve, practicing their assault on recreations of the enemy trenches. Additional preparation occurred, from scouting the enemy wire, right up to the night before the raid to ensure that the gaps in the wire, made by artillery in the weeks prior to the assault, had not been filled in by the Germans. ${ }^{309}$ A diversionary dummy raid was also planned by the $18^{\text {th }}$ and $19^{\text {th }}$ Battalions. Artillery had proceeded to cut the wire in many places along the $2^{\text {nd }}$ Division front, attempting to delude the Germans as to the location of the eventual major assault. ${ }^{310}$ Due to the scale of the undertaking planned, it was no secret to other Canadian battalions that a very large operation was being prepared. "Rumours have been flying around that a big raid is to be carried out by the $4^{\text {th }}$ and $5^{\text {th }}$ Brigades, while the $6^{\text {th }}$ Brigade is to make a feint attack," 311 noted Private Fraser of the $31^{\text {st }}$ Battalion. Another interesting characteristic of the Calonne raid was the extent of which deception featured into the operational planning. During the previous month, a number of smaller raids were carried out in the vicinity of Double Crassier, including a "strong raid" by the $16^{\text {th }}$ and $26^{\text {th }}$ Battalions, who attacked 2300 yards south of the Calonne raid area. The official report observed that "this successful operation undoubtedly went far to allay the suspicions of the enemy and to divert his attention from the activity on the area for our operation." ${ }^{312}$ Raiding had

\footnotetext{
${ }^{307}$ LAC, RG9, v.4930, "21 st Battalion Operation Order No. 73," 16 January 1917.

${ }^{308}$ Godefroy, 27.

${ }^{309}$ Godefroy, 28, and LAC, RG9, v.4106, 22/6, "Report on Minor Operation Carried out by the 4 th Infantry Brigade," 17 January 1917.

${ }^{310}$ Godefroy, 29.

${ }^{311}$ Fraser, 243.

${ }^{312}$ LAC, RG9, v.4106, 22/6, "Report on Minor Operation Carried out by the $4^{\text {th }}$ Infantry Brigade," 17 January 1917.
} 
evolved to the point where major battle raids were supported by smaller stealth raids, which were in turn supported by artillery shoots and patrols.

The raiders were to be very heavily armed, for their planned deep raid was organized around capturing and holding the enemy territory against counterattack. This would not be a "hit and run" raid, but a "hit and hold," with the object of inflicting casualties, and eventually withdrawing after a longer period occupying the enemy lines. Riflemen and bombing parties would be accompanied by carriers, sappers with gun cotton for wrecking dugouts and emplacements, wire-cutters and stretcher-bearers, with the second wave featuring a heavy concentration of Lewis machine gunners. For destructive work on the enemy trenches, the raiders were heavily armed with grenades and Stokes bombs. ${ }^{313}$ The grenadiers equipped themselves with "bomb vests" of haversacks on their chests "in the manner prescribed for the box respirator in the Gas Alert Position," which left the raider's hands free to wield a rifle and bayonet. ${ }^{314}$ Despite these weapons, synchronized watches were seen as absolutely vital to the raid, as the whole operation was on an exact timetable, with any deviation seen as disruptive. ${ }^{315}$ The report later concluded that "the watch was found to be the most reliable method of arranging advances and withdrawal. The signals as arranged were observed by few." ${ }^{\$ 16}$ In raiding, even the smallest tool could provide a tactical advantage.

The emphasis of the attack was to assault the strong German defences of machine guns and mortars piecemeal - so they could not mutually support each other. Positions were to be isolated, flanked, and then destroyed by rifle grenades, or stormed and bombed by the infantry.

\footnotetext{
${ }^{313}$ Godefroy, 28.

${ }^{314}$ LAC, RG9, v.4106, 22/6, "Report on Minor Operation Carried out by the $4^{\text {th }}$ Infantry Brigade, Appendix 'A, 'Conclusions,' '\#16,"' 17 January 1917.

${ }^{315}$ LAC, RG9, v.4106, 22/6, "Report on Minor Operation Carried out by the $4^{\text {th }}$ Infantry Brigade," 17 January 1917.

${ }^{316}$ LAC, RG9, v.4106, 22/6, "Report on Minor Operation Carried out by the $4^{\text {th }}$ Infantry Brigade, Appendix 'A,'

'Conclusions,' ‘\#7,'” 17 January 1917.
} 
Intensive artillery, trench mortar, and machine gun support was allocated to the assault. Even cooperation with aircraft was organized, but weather prevented the planes taking part in the raid. ${ }^{317}$ The scale of the operation was a far cry from the early small raids from 1915 and 1916 , with the planning nearly indistinguishable from major battles except for the scale of the assault.

The attack at 0745 on the German lines, caught the enemy by surprise, as they had just called their "stand down" and were going about their daily routine. Artillery pounded the trenches and fortifications, and the raiders stormed through their arranged gaps in the enemy wire, quickly overcoming enemy opposition. A few machine gun positions offered resistance, but they were quickly dealt with using complex assault tactics utilizing a Lewis gun to pin the enemy down, and then on the flanks men charged with bayonets and bombs to silence the position. ${ }^{318}$ The diversions and deception had paid off, for "the enemy barrage was very erratic. The only determined bombardment took place near the Double Crassier." 319 This was the location of the diversionary attack, not the actual raid. The men from the $20^{\text {th }}$ and $21^{\text {st }}$ Battalions assaulted down the front line and communications trenches. Private Fraser recalled the effectiveness of the first part of the raid: "In four minutes the enemy front line was reached and in twenty minutes we were in to his supports to a length of three hundred yards...enemy dugouts were blown up and set afire by throwing Stokes' bombs with petrol cans of oil attached, creating considerable casualties.",320

As the first wave secured the front lines, the second and third waves passed through them to drive to the final two objectives. Bombers and riflemen advanced quickly, assaulting down

\footnotetext{
${ }^{317}$ LAC, RG9, v.3858, 82/4, "Raids Carried out by Canadian Corps during period from $1^{\text {st }}$ January to $16^{\text {th }}$ February, 1917," 20 February 1917.

${ }^{318}$ LAC, RG9, v.4106, 22/6, "Report on Minor Operation Carried out by the $4^{\text {th }}$ Infantry Brigade," 17 January 1917. ${ }^{319}$ Ibid.

${ }^{320}$ Fraser, 244.
} 
enemy support trenches "Cowboy," "Cougar," "Cooling," and "Coyote." 321 They were followed by the sappers, who destroyed dugouts and emplacements in the wake of the assault. Enemies not killed or taken prisoner tried to flee overland, but that had been anticipated by the Canadians who had set up ready Lewis gun positions. They cut the fleeing Germans down as they ran. If the enemy refused to come out of the sanctuary of their dugouts, they were bypassed by the assault squads and left to the engineers, who entombed them in their dugouts with mobile demolition charges. ${ }^{322}$ At 0830 the attackers commenced their withdrawal, having been in the enemy trenches for nearly an hour. Covered by artillery and Lewis guns, the forward waves fell back through the preceding waves, covering each other as they leapfrogged backwards towards enemy lines. The withdrawal was aided by the sappers who exploded an ammonal tube in No Man's Land, which created a small friendly sap in which the raiders could withdraw for at least a short distance somewhat sheltered from enemy fire. By 0840 it was all over, with the remaining raiders returning to their own lines, dragging killed and wounded comrades with them, along with dazed prisoners who were enlisted to assist in that task.

The gains made by the raiders were equal to the scale of the undertaking, with a destruction report of 43 dugouts, four machine gun and trench mortar emplacements, two trench mortars, one machine gun, and "the trench system generally wrecked." 323 In addition, the enemy battalion headquarters was destroyed, as were their communications lines, which was part of the reason the German response in support of their beleaguered garrison was so erratic and belated. The raiders also captured a German officer and 22 privates, along with two machine guns and

\footnotetext{
${ }^{321}$ LAC, RG9, v.4106, 22/6, "Report on Minor Operation Carried out by the $4^{\text {th }}$ Infantry Brigade," 17 January 1917. 322 Ibid.

${ }^{323}$ LAC, RG9, v.3858, 82/4, "Raids Carried out by Canadian Corps during period from $1^{\text {st }}$ January to $16^{\text {th }}$ February, 1917," 20 February 1917, and Godefroy, 30-31.
} 
two "fish tail bomb throwers." ${ }^{324}$ The raid was an astounding success, but the Canadians also took casualties. The first wave suffered the most, as they had to fight through the initial resistance of German machine gunners. In total, the Canadians lost 40 killed and 135 wounded..$^{325}$

The Calonne raid was another demonstration that the Canadians were applying to operations the lessons learned from the bloody debacles on the Somme and previous raids. These important lessons had been circulated throughout the Corps, moving up the chain of command to Corps headquarters, where many were codified and sent back down for lower headquarters to augment what Byng termed "any new form of Bosche killing. ${ }^{\prime 326}$ Most importantly, the Calonne raid was a clear foreshadowing of operational battle-craft that the Canadians would apply to future major operations. These newer battle raids were miniature battles that differed from the set-piece assaults only in number of troops committed, the scale of the operation, and that they were not aimed to hold the ground they assaulted. They even had their own support operations, whether they were artillery shoots, patrols, or small raids. These were still "butcher and bolt" operations, only the butchering was on a much bigger scale and lasted longer before the raiders decided to bolt.

\section{Raiding and Intelligence}

Raiding not only had a marked effect upon the adoption of new technological innovations and infantry tactics, but it served a vital component in reconnaissance and intelligence. ${ }^{327}$ Captain Alfred Andrews of $2^{\text {nd }}$ Battalion recounted the value of intelligence gathering: "The night was dark and we put on a raid...we got a prisoner and our identification for Brigade. Every

\footnotetext{
${ }^{324}$ LAC, RG9, v.4106, 22/6, "Report on Minor Operation Carried out by the $4^{\text {th }}$ Infantry Brigade," 17 January 1917.

${ }^{325}$ Godefroy, 32.

${ }^{326}$ Cook, Shock Troops, 59.

${ }^{327}$ Dan Jenkins, "Winning Trench Warfare: Battlefield Intelligence in the Canadian Corps, 1914-1918." (Unpublished PhD. Thesis, Carleton University, 1999), 121-122.
} 
once in a while a raid had to be pulled in order to find where the various units of the Germans were. If certain troops were in front it meant trouble and if they were troops who had been in the fighting somewhere else we knew they were in for a rest and we needn't worry." 328 Canadian commander Lieutenant-General Byng, during the preparation for the Vimy offensive, used frequent raiding as a means of providing accurate trench maps to determine targets for the massive artillery bombardment. In the weeks before the attack on Vimy Ridge, raids were sent over nearly every night in attempts to gather accurate information for the gunners. ${ }^{329}$ The PPCLI, for example, launched three major raids from March $26^{\text {th }}$ to $28^{\text {th }} 1917$. The first one failed but the other two succeeded - yet only after hard hand-to-hand fighting. ${ }^{330}$ These raids, while performing their usual role of intelligence gathering and materiel destruction, provided the gunners with details of enemy fortifications upon which to concentrate their fire once the "big show" started. ${ }^{331}$ The information that the raiders had provided to the gunners for the week-long preparatory bombardment on Vimy Ridge was so accurate, that a final series of raids by the $1^{\text {st }}$ Division, the day before the assault on 9 April, revealed that along their axis of advance there remained only one trench system left unscathed by the bombardment. ${ }^{332}$ The evolving symbiosis between raiding and artillery arguably saved many Canadian infantrymen's lives at Vimy.

Such intensive raiding, however, took its toll on the fighting efficiency of the Canadian units. Lieutenant James Pedley of the $4^{\text {th }}$ Battalion remembered the difficulties he and his comrades experienced while raiding under a condensed timeline: "The object was to gain identification of the enemy opposite our lines, and at any cost. If a raid should fail, other means must be employed... [A]ll our plans were bent toward making the operation a success. And after

\footnotetext{
${ }^{328}$ CLIP, A.H.J Andrews diary, 4 March 1917.

${ }^{329}$ Rawling, Surviving, 106.

${ }^{330}$ LAC, WD, PPCLI, 26-28 November 1917.

${ }^{331}$ Rawling, Surviving, 110.

${ }^{332}$ Rawling, Surviving, 111.
} 
it was over our attention was fully occupied in explaining away its failure, in making the most of a badly botched job, and in contriving some means of doing what the raid failed to accomplish..."333 The raid Lieutenant Pedley described was in fact nearly able to achieve its objectives, as he continued to explain the fine line between success and failure in a raid: "One of our officers had, in fact, cut down a German - but in his excitement had brought home with him nothing but the man's worthless trench helmet... when an epaulet...would have made the raid a success! How we cursed the luckless officer, and how he hated himself when he came to look back on his feat!"334 Obtaining information from the enemy was always a difficult and dangerous job for Canadian raiders, and many times when the raiders came up short, their commanders ordered them to do it again until information was obtained.

\section{Costly Failed Raids: The $4^{\text {th }}$ Division 1 March 1917 Raid}

One of the primary roles of raiding was to destroy the enemy morale as part of the overall battle of attrition. Yet that attack on morale could work against the raiders, particularly when raids went wrong, casualties mounted, and many good fighting men lost their lives. This is especially evident in light of the 1 March 1917 raid. It was one of the largest raids ever carried out by the Canadian Corps, and their most significant failure. The raid was executed by battalions from the $4^{\text {th }}$ Division, which were relatively new to the battlefield on the Western Front and who were eager to make their mark, especially in relation to the other three veteran Canadian divisions.

The preparation was intensive but the operation was flawed from the start. This large raid was organized at the divisional headquarters, as opposed to the battalions engaged in the forthcoming operation doing the planning. This was one of the major drawbacks from the

\footnotetext{
${ }^{333}$ Pedley, 250-251.

${ }^{334}$ Pedley, 263-264.
} 
systematization of raids into established doctrine. As part of the dramatic attack, the planners chose to forego artillery support for the raiders in favour of a poison gas cloud, an experiment that had never been tried before. To date, artillery, mortar, and rifle grenades had been essential in any large-scale attack, and the use of poison gas was completely different. When the divisional planners presented their strategy, they overrode the objections from their experienced veteran junior commanders, who predicted all manner of problems with the reliance on gas, with which the infantry had almost no training. ${ }^{335}$ This was one case where battle planning was totally divorced from the realities on the front, and was symptomatic of the gradual change in raid planning from the lower levels of command to officers who were further up the chain of command - and further away from the vital front line perspective. Corporal Will Bird of the $42^{\text {nd }}$ Battalion, after witnessing a previous failed raid, elucidated this problem of raid planning becoming too concentrated in the hands of upper command: "As with so many elaborately planned affairs that look so good on paper, all did not go as expected...At any conference regarding raids I had but one point to make...never plan a raid on paper. There was continual change in enemy posts and in enemy tactics...But I was always talked down. The sticklers for paper work were in command. ${ }^{, 336}$ As was the case with the raid that Corporal Bird was discussing, the March 1 Gas Raid was one instance where the derogatory phrase "Lions led by Donkeys" certainly held true.

After several costly delays in waiting for the proper wind conditions, which alerted the Germans to the impending attack, the gas was finally released on 1 March. The Germans

\footnotetext{
${ }^{335}$ Cook, "A Proper Slaughter," 15.

${ }^{336}$ Bird, 128-129.
} 
remained unharmed, having had ample time to don their gas respirators. ${ }^{337}$ Maurice Bracewell of the $102^{\text {nd }}$ Battalion recounted the failure in command that cost many skilled raiders their lives:

A big raid into the German lines by two [sic, four] battalions on a Brigade front was planned...The German staff knew all about the impending attack and were sitting waiting for it. The gas was turned on prior to the start of the artillery barrage and the men stood in it in their gas masks...The wind was blowing very strongly right into our own lines!...The Colonels of the attacking Battalions were reported as protesting the ruling most vehemently but the Army Brass was adamant in their stand... Most of them were cut down as soon as they started out. The enemy had his artillery and Machine guns concentrated on that piece of frontage. Our own lines got all the gas, the front trenches were saturated with it. ${ }^{338}$

The Canadians, when all the dead were finally collected and counted, had suffered a staggering forty-three percent casualty rate of the 1600 men who went over the top. ${ }^{339}$ Private Bert Cooke of the $75^{\text {th }}$ Battalion remembered the magnitude of the defeat: "Our battalion suffered heavy losses, at the same time losing our Colonel [Beckett] and Adjutant. Also ten other officers and one hundred fifty men were wounded. Fifty-five men were killed and ninety men were missing." He continued to describe the slaughter's effects on his comrades, "The men came out for a rest on March 2, and they needed it badly after doing such work. Nevertheless, it was a sad day knowing we had lost so many men...Our sadness continued...as we buried the Colonel and the Major...”340 With the appalling slaughter of so many skilled men and officers, those that remained in the $54^{\text {th }}$ and $75^{\text {th }}$ Battalions must have had a severe loss of faith in the wisdom of command decisions.

\footnotetext{
${ }^{337}$ E.L.M. Burns, General Mud: Memoirs of Two World Wars. (Toronto: Clarke, Irwin \& Co. Ltd., 1970), 39.

${ }^{338}$ CLIP, Maurice Bracewell, memoirs, 1 March 1917.

${ }^{339}$ Cook, Shock Troops, 70.

${ }^{340}$ Cooke, 102.
} 
The number of dead Canadians was so high that a temporary local cease-fire was established between the Canadian and German lines so the Canadians could collect their numerous dead from No Man's Land. Maurice Bracewell, a soldier in the $102^{\text {nd }}$ North British Columbians who were acting in support of the raid, described in his memoir this instance of live and let live: "The whole front area was in such a state that a 36 hour cease fire had to be arranged to get it cleaned up...We worked night and day on burial parties and even traded dead with the German burial parties." ${ }^{341}$ Raiding, which usually was a force to destroy notions of live and let live on the battlefield, was, in this case, a catalyst for it.

Experimentation, one of the cornerstones in the development of raiding, was characterized by trial and error, and the 1 March raid was a fatal error of catastrophic proportions. While it was necessary to experiment, the $4^{\text {th }}$ Division had done little to train the raiders in how to incorporate poison gas into their attack doctrine, and they seemed to simply hope that it would work. On the Western Front, hoping for success generally led to defeat. Such failures brought up issues of accountability and blame, especially when the raiding battalion headquarters objected to the plan and was overruled by divisional headquarters. ${ }^{342}$ Failure at raiding taught valuable lessons, but could also harm morale. The $75^{\text {th }}$ Battalion's Private Bert Cooke was moved to write a poem in remembrance of the terrible tragedy that he witnessed:

There was nothing much done till away in March, then a raid was pulled off one night in the dark. / Old Fritz seemed to know we were coming just then. $\mathrm{He}$ outnumbered our boys again and again. / Some gas was put over, but turned with the wind, the Huns they all knew it and just simply grinned. But the boys they went over and tackled them right, we got in their trenches and made them all fight. / On this

\footnotetext{
${ }^{341}$ Ibid.

${ }^{342}$ Ashworth, 142.
} 
occasion we will never forget, all the boys in the outfit will tell you that yet. We lost our Colonel and Major Langstaff, they died like heroes, they fought till the last. / They lay in the graveyard not far from the Ridge, with others beside them that fell as they did. They did their duty that terrible night, we will never forget that month or fight. / We relieved the next day we came out for a rest, we needed it badly the biggest and best. Our outfit was crippled, the men badly beat, our clothes were all torn, and kit-that all went. Our Colonel was gone, some officers too, those that were left said, 'what shall we do?'343

The failure of the 1 March raid was felt throughout the ranks of those involved, and eventually throughout the entire Canadian Corps via rumour and shared reports, as a lesson in futility and waste. If there was any consolation, the raid re-taught very hard lessons that admittedly should have been known already to those organizing the enterprise, and it also served as a poignant reminder of the sheer danger and immense risk of trench raiding, and what happened when planners diverged from established doctrine, past lessons, and the philosophy of careful planning and preparation that had made past Canadian raids successful.

\section{Failed Raids, the Will to Fight, and Morale}

The harsh reality of minor operations was that they were not always perfectly executed, and despite the Canadian's expertise in performing these minor operations with skill and efficiency, especially during the 'professional' phase in the spring and summer of 1917, it was rare when a formation of raiders did not suffer casualties. While all losses were to be lamented, the killed raiders tended to be the best and most aggressive fighters in the battalion. This was where Haig's strategy of constant attrition, and the resulting doctrine of relentless raiding

\footnotetext{
${ }^{343}$ Cooke, 106. Note: The quote above was edited for brevity's sake, as Private Cooke's moving poem was much longer than quoted.
} 
throughout the Canadian Corps, worked against itself. Raiding was essential to hone the soldiers' battlefield skill set, but when engaged in too often these raids were harmful, as they killed off the best fighters and most aggressive junior officers. ${ }^{344}$

Due to the losses in men, morale, and materiel from failed raids, these minor operations could be viewed as counterproductive to the fighting efficiency. Edmund Blunden, who was not a Canadian soldier but witnessed many similar events while serving in the $11^{\text {th }}$ Royal Sussex Regiment, said this about raids:

I can say that our greatest distress at this period was due to the short and dry word 'raid'. Adducing one reason or another, the lowering of the enemy's spirits, the raising of our own, the identification of some supposedly new troops opposite, the damaging of the German trenches, the Great Unknown behind us were growing infatuated with this word. ${ }^{345}$

Raids were dangerous undertakings no matter the extent of planning or preparation, and they put great strain on the men - especially if they resulted in failure. "If, as we approached that locality, some disgruntled soldier was heard to say that the raid was a rotten failure, with nothing to show for it but our own casualties, we passed him by contemptuously as a grouser. But it was the truth, nevertheless," wrote Lieutenant Pedley of the $4^{\text {th }}$ Battalion "We had had a dozen casualties, of which two were fatal...The whisper went around that these casualties were the work of our own barrage. The tape had been laid too far out, rumour had it - a scant hundred yards from the German line. And the boys had had too much rum; so that they dashed away at the first gun-fire

\footnotetext{
${ }^{344}$ Cook, At the Sharp End, 301.

${ }^{345}$ Edmund Blunden, Undertones of War. (London: Cobden-Sandersen, 1930), quoted in Ashworth, 186.
} 
and ran right into it." 346 With raids failing from the slightest misstep, or merely from bad luck, performing on the razor's edge eventually took its toll.

Frequent raiding sapped the courage out of even the most grizzled veterans. Perhaps the loss of men and morale due to constant raiding was not worth the tactical or strategic gains? The answer is far from simple, and while it is impossible to quantify the building or degrading of morale, what can be ascertained is that the positive lessons from raiding were quite significant in supporting the Canadians' tactical evolution on the battlefield. However, the harsh reality of combat on the Western Front was that, even in success, soldiers died. They died well and they died badly, but the armies were always losing men. Raiding served as part of the strategy of attrition to both sides of the conflict; causing losses in men, materiel, and morale, to the intended victims of the raid and also to the Canadians. Where raiding was perhaps most detrimental in this regard was that those who died were usually the best and most able combat soldiers of a unit. Whether their losses were actually worth the gains in tactical evolution, and the transference of lessons to major battles, cannot be accurately determined, but the vital operational lessons raiding produced cannot be ignored. They were an essential aspect of the advancement of the offensive learning curve. However, these vital lessons were forged in Canadian blood.

\section{Minor to Major Operations: Transference of Ideas}

Raiding tactics during the second era of trench raiding were applied to large-scale operations. One thing that Major-General Louis Lipsett of $3^{\text {rd }}$ Division noticed after a raid by the $1^{\text {st }}$ C.M.R. in late December 1916 was the usefulness of infiltration into No Man's Land prior to

zero hour. $^{347}$ These jumping off points allowed the raiders to sneak closer to the enemy trenches prior to the offensive, reducing the time the attackers had to spend in crossing the killing zone

\footnotetext{
${ }^{346}$ Pedley, 264.

${ }^{347}$ Rawling, Surviving, 103.
} 
between the front line trenches. This concept, developed and experimented during raiding, found its way into the attack plans of all four divisions at Vimy Ridge. Recalling the macro implications of raiding doctrine, Captain Maurice Pope of the $11^{\text {th }}$ Brigade Command Staff noted in a letter to his father:

The confidence and morale of the army is remarkably fine, while the Bosche seems to be drooping. We daily raid, bombard and generally annoy him in a way that he never would have stood when I first came out here. The ease and regularity with which we carry out our smaller operations seems to augur well for the larger ones that will be undertaken later on. Many of our raids are really small offensives with the exception that we make no effort to hold the trench systems that we penetrate. He does not come back at us very often and when he does so his luck is usually out. ${ }^{348}$ While there were sometimes heavy casualties to the raiders, and very few raids that did not result in the loss of some men, the aggressive spirit helped to restore confidence to the Canadians, especially after the terrible blood-letting on the Somme, where the infantry was pounded relentlessly by enemy artillery fire and the attacks were often shattered in No Man's Land before they ever reached an enemy trench.

Raids became laboratories for experimentation with combined arms cooperation. Artillery was proving to be the crucial factor in any successful offensive, and the effective trio of crushing preparatory bombardments, a protective creeping barrage, and infantry-wielded heavy weapons, the combination of which would propel the Canadians to victory at Vimy Ridge on 9 April 1917, were first battle-tested in minor operations. One such experimental and educational raid was executed by the $42^{\text {nd }}$ Battalion on 1 April 1917. The raid featured a complicated barrage of artillery, trench mortars, rifle grenades, and indirect machine gun fire while the raiders

${ }^{348}$ Pope, 79. 
advanced in teams of bombers, riflemen, Lewis gunners, and engineers. ${ }^{349}$ Each squad and support arm had its own vector of fire and its own role in the support of the raiding parties. This provided accurate tactical fire support - bombarding enemy emplacements and troop garrisons. ${ }^{350}$ The men entered the enemy trench under this intense shower of combined arms firepower to wreak havoc among the German communication trenches. The raiders then quickly and efficiently withdrew with only one man wounded. ${ }^{351}$ This example of a combined-arms assault featured the same tactics that the Canadians would employ against the Germans on Vimy Ridge eight days later. ${ }^{352}$ Raiding had evolved to mirror major operations.

\footnotetext{
${ }^{349}$ LAC, WD, $42^{\text {nd }}$ Infantry Battalion, April 1, 1917.

${ }^{350}$ Ibid.

${ }^{351}$ Ibid.

${ }^{352}$ Rawling, Surviving, 106.
} 
CHAPTER III: Battle Raids to Open Warfare, Spring 1917 to Armistice

\section{Minor to Major Operations: Raiding Applied to Vimy Ridge}

The Canadians were well prepared when they attacked Vimy Ridge on the morning of 9 April 1917. Months of intensive preparation, an extensive logistical train, a network of communications, and vital intelligence ensured that the operation went as smoothly as possible. ${ }^{353}$ Raiding also was a key component for preparing the soldiers for the battle; not only in gathering actionable intelligence through smaller raids, but also in that the larger battle raids in the early half of 1917 resembled major battles, differing only in that the raids featured smaller force ratios. ${ }^{354}$ These were, in effect, dress rehearsals for the big show in 9 April 1917.

At 0530 the four Canadian divisions emerged out of their mine tunnels and "jumping off" points to take Vimy Ridge. In victory, the Canadian Corps demonstrated how it had learned and processed key lessons and tactics since the Somme, many of which had been practiced and honed in minor operations. Moreover, the battle planning for the attack on Vimy was arguably simpler than the plans drawn up for the big battle raids such as the 17 January Calonne Raid, as commanders did not have to concern themselves with the tricky withdrawal of troops and evacuation of wounded, prisoners, and intelligence information from hostile territory. Lieutenant C.B.F. Jones wrote home on 15 April 1917 about the preparations for the battle at Vimy: "Our plans worked beautifully. Everything had been carefully rehearsed beforehand; each battalion had its own special work, and weeks before, we had studied the ground in front of our trenches, and the [German] trenches, from aeroplane photographs. ${ }^{, 355}$ In light of their experience in executing large daylight battle raids since December of 1916, assaulting Vimy Ridge would have been familiar tactical territory for many of the seasoned Canadian soldiers.

\footnotetext{
${ }^{353}$ Cook, Shock Troops, 79-80.

${ }^{354}$ Macintyre, Canada at Vimy, 71-72.

${ }^{355}$ LFTF, 201.
} 
The troops on the ground displayed a tactical sophistication that closely resembled the major raids that had been pulled off in the previous months. Many of the battalions used mine tunnels as jumping off points for the attack, a familiar tactic to those raiders who took part in the Lille Road raid on 20 December 1916. This allowed the men on April 9, just as it had during the raids, to attack the German trenches from the most forward position possible in order to avoid being caught in enemy defensive artillery and machine-gun fire. At Vimy, the infantry advanced in small unit tactics, moving forward in sections, each with its individual task, equipped differently to meet their objectives, and often leapfrogging through each other to keep up momentum to reach the final objectives. ${ }^{356}$ The use of leapfrogging tactics, where sections advanced through each other, one covering the advance of the other, to take successive objectives was also foreshadowed by the battle raids of the previous winter's raiding campaign. ${ }^{357}$ The creeping barrage, which contributed heavily to victory, was also previously perfected in battle raids such as the 20 December Lille Road raid or the 17 January Calonne raid. ${ }^{358}$ The assault on Vimy Ridge - in terms of planning, preparation, logistics, tactics, and weaponry involved - was essentially a battle raid on a macro scale, and therein lay the root of its success: the Canadians were taking what they excelled at and practicing it on a much greater scale. With this in mind, once the Canadian soldiers had finished consolidating and digging in on the newly won slopes of Vimy, almost immediately afterwards they looked down towards the Douai Plain in anticipation of another era of trench raiding.

\section{Professional Minor Operations: Raiding into the Summer of 1917}

The Canadians continued to drive eastward after Vimy, attacking Arleux in late April 1917 and Fresnoy in early May. Despite hard fighting, the Canadians succeeded in pushing the

\footnotetext{
${ }^{356}$ LAC, RG9, v.3858, 82/4, "Raids Carried Out By the Canadian Corps, Dec 20 1916," 4 January 191[7].

${ }^{357}$ Ibid.

${ }^{358}$ Ibid.
} 
Germans back. The assault troops and artillery of the Canadian Corps were beginning to develop a very close working relationship, and the change from "fire then movement" to "fire and movement," as evidenced by these campaigns, was essential to victory in the battlefield. In accordance with these large set-piece battles in the spring of 1917, the Corps continued its policy of regular raiding. Raids and patrols were integrated into the main battle plan, being used as means to consolidate territory, and also as a way to prepare for larger assaults. In the coming months, raids would be used to straighten out defensive lines, which had transitioned from harddefined trenches with thick belts of barbed wire to a more flexible outpost-based defensive system. ${ }^{359}$ The German defensive outposts projected into No Man's Land, often in a checkerboard defence, and would be more concentrated towards the reserve battle lines. These changing defensive strategies, utilized on both sides of the battlefield, were in response to the power of the artillery bombardments and the coordinated infantry assault, as witnessed at Vimy Ridge. A looser front line allowed for flexibility in reaction to an attack, and minimized casualties from crushing artillery bombardments. These looser defensive lines also meant the Canadians had to adjust their raiding strategy. It became more difficult for raiders to capture enemy sentries or inflict great casualties on the Germans, usually while they lay vulnerable in their deep dugouts, because the front lines were only very thinly held, and as soon as a raid was detected, the sentries raised the alarm and fled - leaving the Canadian raiders to face the inevitable counterattack in force. ${ }^{360}$

Only a few weeks after Vimy, the $49^{\text {th }}$ Battalion raided Saline Trench in the Douai Plan. Despite thorough preparation and intelligence, and overcoming enemy posts in quick succession, the raiders quickly ran into stiffer resistance further down the trench system. Enemy sentries,

\footnotetext{
${ }^{359}$ Bennett, S.G. The $4^{\text {th }}$ Canadian Mounted Rifles 1914-1918. (Toronto: Murray Printing Co. Lt., 1926), 66.

${ }^{360}$ Bennett, 109.
} 
seeing the raiders, fled to their rearward positions to summon reinforcements to counterattack. The Canadian raiders were then subjected to heavy interlocking machine gun fire from rearward positions of the enemy's checker-board defensive grid, forcing their withdrawal. This was facilitated by covering patrols in No Man's Land, and the raiders were fortunate to return to their lines with only one wounded man. ${ }^{361}$ The battle raid was no longer producing heavy enemy casualties and the procurement of prisoners: new raiding tactics were needed.

Throughout raiding's third era, raids continued to assist in the development of combined arms tactics. Infantry support weapon tactics, such as using machine guns to accompany the infantry assault, continued to benefit from experimentation and practice in aiding these minor operations. On 26-27 May 1917, a Canadian machine gun squadron after-action report noted new lessons about how it had supported a raid carried out by the Canadian Cavalry Brigade near Somerville Wood. Experimentation in positioning guns on extreme flanks for enfilading fire, the employment of new luminous sights for night time firing, the use of "very narrow deep trenches behind each gun" to protect the gun teams from enemy fire but also allow them to stay in action at the same time, and the deployment of defensive patrols to screen the valuable gun teams in case of an enemy counter-raid, were all noted and analysed in the report, and then sent on to higher commands. ${ }^{362}$

Raids in the summer of 1917 foreshadowed future changes to minor operations, with their role becoming increasingly tied to not only the destruction of enemy morale and materiel, but also to the eventual occupation of ground that had been overrun during raids. On 30 August 1917 , the $58^{\text {th }}$ Battalion raided an area known as Nun's Alley on the outskirts of the town of Lens. According to Brigadier-General F.W. Hill's report, the raid was carried out with the

\footnotetext{
${ }^{361}$ LAC, RG9, v.4154, 8/6, “Report on Raid,” 25 April 1917.

${ }^{362}$ LAC, RG9, v.3984, 1/19, "Report of action of Canadian Machine Gun Squadron regarding raid carried out by Canadian Cavalry Brigade," 30 May 1917.
} 
following directive concerning the German strongpoint in the sector: "In order to deprive the enemy of this advantage, and to secure for ourselves a similar command of the enemy's trench system, and to enable us to construct our proposed trench east of our present front line, the $58^{\text {th }}$ Battalion was ordered to clear Nun's Alley as far as the crest and to establish a post there."”63 While in the enemy trenches, the $58^{\text {th }}$ Battalion's raiders established a trench block in order to hinder German counterattacks. As the Canadians defended this position, an enemy assault "was delayed by this obstacle...the precision of the rifle grenade fire stopped his advance, inflicting severe casualties. ${ }^{\not 64}$ Raids in late 1917 were becoming essential vanguards to the actual occupation of enemy territory, clearing the way of enemy resistance and strongpoints, foreshadowing the role raids would play in the Hundred Days offensives a year later.

\section{Raids instead of Battles: The $3^{\text {rd }}$ and $4^{\text {th }}$ Division Avion Raid, 8-9 June 1917}

Throughout the summer of 1917 , the Canadians continued to carry out the policy of attrition through major raids. One of the larger operations undertaken during this period was on 8-9 June, where parties from the $3^{\text {rd }}$ and $4^{\text {th }}$ Divisions cooperated to launch a large raid in the Avion Sector. ${ }^{365}$ The plan for this raid was to replace a battle, as a raid was more practical and effective because the Canadians did not have the resources available to expend energy in holding the territory they had captured. The raid would form part of the prolonged offensive against the German defences east of Vimy, where the Canadians were tasked with driving the Germans from the Lens / Avion sector in anticipation of the strike on German-fortified Lens later in the summer. In this period of "continuous aggression," the Canadians encountered stiff resistance from the enemy, especially as the infantry advanced rapidly, quickly outstripping the supporting

\footnotetext{
${ }^{363}$ LAC, RG9, v.4149, 15/5, dispatch, Brigadier-General Hill, "Report, $58^{\text {th }}$ Canadian Battalion, 33/333," 31 August 1917.

${ }^{364}$ Ibid.

${ }^{365}$ Reynolds, 145-146.
} 
artillery's ability to keep pace, leaving the attackers vulnerable while they attempted to hold their newly won ground against enemy counterattacks. ${ }^{366}$ After some deliberation with MajorGenerals Louis Lipsett of the $3^{\text {rd }}$ Division, and David Watson of the 4th, Lieutenant-General Julian Byng concluded that the same operational goals of a battle, the driving off of Germans from their positions in the Avion sector, could be achieved by a large battle raid. The attack would be essentially the same, differing only in that, after overcoming the enemy's resistance, capturing prisoners, and destroying their emplacements, they would withdraw rather than attempt to permanently hold the ground with little artillery support. General Sir Henry Horne, commander of the First Army and Byng's superior, agreed with the operational plan for these attacks to be carried out as large-scale raids, rather than battles. ${ }^{367}$ In this melding of raids into operations similar to, or as a precursor to, minor attacks, raids were becoming more and more associated with the occupation of ground, but they still maintained emphasis on hit-and-run tactics.

The raid called for the participation of six battalions, making it one of the largest raids of the war. The $4^{\text {th }}$ Division's $11^{\text {th }}$ Brigade would carry out the raid on the left flank with raiders from the $75^{\text {th }}, 87^{\text {th }}$, and $102^{\text {nd }}$ Battalions. The right would be attacked by the $3^{\text {rd }}$ Division's $7^{\text {th }}$ Brigade, which tasked the $42^{\text {nd }}, 49^{\text {th }}$, and Royal Canadian Regiment with carrying out their section of the attack. ${ }^{368}$ Corporal Will Bird of the $42^{\text {nd }}$ Battalion remembered the anticipation for the raid, and the preparations that were being undertaken: "Everyone was excited about a Brigade raid to be staged on the night of June 8. The Hun front line and second lines were to be taken, held for a time and then vacated....tapes were laid to the front line, white lines that led to

\footnotetext{
${ }^{366}$ Ibid, 145.

${ }^{367}$ Ibid, 146 .

${ }^{368}$ LAC, RG9, v.4199, 7/6, "Report on Minor Operation, 8-9 June 1917," 11 June 1917. See also Reynolds, 146.
} 
first aid stations, and guides for bringing back prisoners overland. In the dark they looked like pathways for ghosts."369

In anticipation of the raid, the battalions' raiders were sent to rearward areas in the weeks prior to the raid to practice on taped courses, day and night. With the attack devolving from battle to major raid, new ideas were incorporated from recent experience in raiding, mainly in the organization of raiding parties, small-unit assault tactics, and in inter-formation organization. The raiders trained intensely, intending to practice a new platoon organization in the raid, and also to incorporate Lewis guns in the assault, which were to fire while on the move as forward infantry support weapons. ${ }^{370}$ The attack plan also called for the raiders to advance using the newer tactic of the leap frog system, an infantry tactic that had proven its effectiveness in previous raids and at Vimy." 371 Gigantic maps covering dozens of square metres were drawn up so details of the operation could be shown to the entire raiding force. ${ }^{372}$ Further preparation included having the raiders spend time reconnoitring the objective area in nightly patrols, in order to be better acquainted with the terrain. ${ }^{373}$

Support for the raid was extensive, with as many trench mortars, artillery pieces, and machine guns as the divisions could muster. The $11^{\text {th }}$ Brigade's fire support, for example, consisted of four brigades of field artillery, three 6-inch heavy batteries, and one 9.2-inch heavy howitzer battery. ${ }^{374}$ Supporting fire was tasked with destroying wire to allow the raiders to storm the trenches, with the same bombardment then raking over the enemy lines in a creeping barrage

\footnotetext{
${ }^{369}$ Bird, 47.

${ }^{370}$ LAC, RG9, v.4148, 14/7, "Report on Minor Operation, "Training," 11 June 1917.

${ }^{371}$ LAC, RG9, v.4199, 7/6, "Report on Minor Operation, 8-9 June 1917, "Plan of Attack," 11 June 1917.

372 Reynolds, 146-147.

${ }^{373}$ LAC, RG9, v.4199, 7/6, “Report on Minor Operation, 8-9 June 1917, 'Preparation,"” 11 June 1917.

${ }^{374}$ Reynolds, 147-148.
} 
that would form a protective screen around the raided area. Additional artillery was tasked with counter-battery duty, in order to neutralize the German artillery response to the raid. ${ }^{375}$

At 2330 on the night of 8 June the raiders, numbering approximately 2,500 men, infiltrated No Man's Land to their jumping off positions. ${ }^{376}$ At 2345 the barrage commenced, and the raiders followed it into the enemy trenches. At times the raiders followed the barrage so closely that the enemy machine gun positions, cowering from the intense high explosives, did not have enough time after the barrage lifted to re-man their weapons. Corporal Bird noted, as a response to the massive raid against their lines, "the Germans were sending up orange sprays, red rockets, green flares, golden chains, seemingly all the varieties they had, but their artillery made small response." 377 The German heavy guns opened at 2351 , but featured "scattered shelling, but did not law down any definite barrage." 378 The three attacking battalions of the $7^{\text {th }}$ Brigade took their objectives with relative ease, with after-battle reports noting the poor state of the German trenches due to the Allied artillery bombardment, except occasional enemy machine gun emplacements which fought to the death. The R.C.R. encountered one such position, but utilized small arms tactics, pinning it down with Lewis guns and rifle grenades while a squad of grenadiers manoeuvred to its flank and bombed it out of action. ${ }^{379}$

The $11^{\text {th }}$ Brigade met with considerably more resistance. The $87^{\text {th }}$ Battalion encountered a heavily held secondary line in the enemy trenches, and faced resilient enemy emplacements of machine guns. It was only by the effective leadership and initiative of the junior commanders

\footnotetext{
${ }^{375}$ Ibid.

${ }^{376}$ For discussion on the numbers of troops committed, see the Reynolds article. Official reports describe numbers of troops committed in terms of platoons and companies, and the Reynolds article only mentions concrete figures for the $7^{\text {th }}$ Brigade, so therefore the figure of 2,500 total raiders is to be taken as a rough estimation. What can be ascertained with certainty, however, that this raid was indeed huge in scale and probably the largest to be carried out during the entire war.

${ }_{377}^{37}$ Bird, 48.

${ }^{378}$ LAC, RG9, v.4148, 14/7, "Report on Minor Operation, 'Training,", 11 June 1917.

${ }^{379}$ LAC, RG9, v.4148, 14/7, "Report on Minor Operation, 'Narrative,"” 11 June 1917.
} 
that the raiders were able to maintain platoon cohesion and overcome the entrenched enemy, sometimes resorting to vicious hand-to-hand combat. ${ }^{380}$ The $75^{\text {th }}$ Battalion also met with stiff fighting in its area of operations, with enemy machine guns causing severe casualties to the assaulting platoons. They caused many enemy casualties, and destroyed a number of dugouts and weapon emplacements, but were unable to achieve their final objective due to the ferocity of the enemy small arms fire. ${ }^{381}$ At $2345102^{\text {nd }}$ Battalion, which was attacking on the extreme right of the assault area, was actually raiding for the second time that night. Their first raid commenced at 2030 , and the men of the $102^{\text {nd }}$ attacked the Germans opposite their position with swiftness and ferocity, overpowering the garrisons in close quarters combat and in a flurry of grenade explosions. Their objectives met, they handed over their newly won territory to the British battalion that was moving in to relieve them. ${ }^{382}$

Their second raid capitalized on their first, but suffered due to exposed jumping off positions, and, because they had raided the area mere hours earlier, there was absolutely no chance of surprising the enemy. Following their barrage into the enemy lines, the raiders encountered thick wire, and were beset by German artillery while exposed in the open. Their casualties mounted, and the attack faltered. Friendly artillery could not assist, for the raiders were already too close to the enemy lines, and all attempts at rallying forward failed. The men of the $102^{\text {nd }}$ then retreated back to their jumping off position to allow the artillery and recently arrived support machine guns to pour their fire on the enemy positions. The men of the $102^{\text {nd }}$ suffered heavy casualties, some of which came from the position they had thought was in British hands - who had in fact had been dislodged by German raiders while the Canadians executed

\footnotetext{
${ }^{380}$ Reynolds, 158.

${ }^{381}$ Ibid, 160.

${ }^{382}$ Ibid, 162.
} 
their main raid. Heavy casualties occurred when the raiders walked into an ambush of machine guns, rifles, and grenades, leading to a further 30 casualties.

Despite the preparation and efficient execution of the operation, the raiders still encountered problems. One of the major setbacks was the failure in reliable communications. The attacking battalions, which were synchronized by watches and visual flares, were not overly affected at the sharp end, but their support weapons behind the point of attack were for a large part of the raid left without reliable means of coordinating support for the assault. "Not only did these [telephone] lines go out almost immediately, but the overland lines between Battalion Headquarters and Brigade advance report centre were continually out...Visual station was established...but...it was of practically no service. ${ }^{383}$ Despite great advancements in tactics and weaponry, vital communications between front lines and the support elements of command, artillery, and signals were still woefully inadequate. This explains the raiders' continued reliance on strict timetables, extensive preparation and contingency planning, and obsession with synchronized watches.

The raiders also encountered stiff enemy resistance, despite their own weight of fire and tactical efficiency. The fact that right before zero hour the weather turned rainy and overcast, and the night becoming especially dark, proved to be a severe hindrance to such a huge undertaking with such a large force ${ }^{384}$ With a total of about 700 casualties, or nearly $30 \%$ of the total number of raiders committed to battle, the raid cost the Canadians dearly. ${ }^{385}$ Major-General Lipsett, in commenting on the casualties accrued by his $7^{\text {th }}$ Brigade, noted "I regret that our casualties were so high, but most of those were slight wounds, and I think we may reasonably expect that the

\footnotetext{
${ }^{383}$ LAC, RG9, v.4154, 8/5, "Narrative of Raid, 42 ${ }^{\text {nd }}$ Battalion, 'General,"” 10 June 1917.

${ }^{384}$ LAC, RG9, v.4148, 14/7, dispatch " $3^{\text {rd }}$ Canadian Division, G.321," 12 June 1917.

${ }^{385}$ Reynolds, 164.
} 
German casualties are much higher., ${ }^{386}$ The raid, one of the largest carried out during the whole war, was indeed successful on that account, with an estimated 1,000 enemy casualties caused, along with the capture of over 60 German soldiers, and the destruction of 78 enemy dugouts. ${ }^{387}$ Undoubtedly optimistic in their estimations, these reports nonetheless conveyed the sentiment that the raid inflicted severe damage on the enemy.

Despite the casualties and setbacks, the raid proved to be a valuable educational experience for the Canadians, who were able to experiment with new platoon organizations, small unit tactics, and logistical strategy. The difficulties encountered, particularly the failure in communications, would serve as lessons for future operations.

\section{Achieving Symbiosis: Raids and Patrols}

Patrols became vital to minor operations of the third era, evolving to become an integral part of the preparation or assault phases of raids. They performed a critical reconnaissance role in preparation for raids, gathering information in the form of detailed sketches of enemy trenches, enemy front line trench activity, and intelligence on possible targets for upcoming offensives. ${ }^{388}$ On the night of 8-9 July 1917, the Canadian Cavalry Brigade raided a trench system near Ascension Wood in the Arras sector, and patrols played a prominent part in the success of the operation. In the days previous to the raid, "a series of patrol encounters...previously carried out on Ascension Wood, had already reduced the enemy's patrolling activities." 389 These fighting patrols were vital to the preparation of the raid, as they resulted in "practically complete command of No Man's Land," and also a detailed analysis of the enemy wire in the area to be

\footnotetext{
${ }^{386}$ Ibid.

${ }^{387}$ LAC, RG9, v.4148, 14/7, "Report on Minor Operation, 'Casualties,"” 11 June 1917.

${ }^{388}$ Rawling, Surviving, 100.

${ }^{389}$ LAC, RG9, v.3995, 7/5, "Account of a Raid by the Squadrons of Canadian Cavalry Brigade, 'Reconnaissance,"” 9 July 1917.
} 
raided. ${ }^{390}$ On the night of the attack, the assault section of the raid, numbering 153 raiders and six officers, was shielded by three covering patrols. These vanguard patrols were positioned one in front of the raiders, and on the two flanks, and numbered over 100 men in total. ${ }^{391}$ The official report for the raid indicated that these "flank and advanced guards" were seen as vital to the screening of the raid, as they allowed the raiders to attack their objectives without interference from enemy defensive patrols. The raid also featured the innovative "use of H.E. shell to direct parties in the dark" towards their objectives, which was an unconventional experiment in attempting to overcome the continual problem of command and control in the assault. ${ }^{392}$ Overall, the raid was a huge success, with the capture of 36 of the enemy prisoner and one machine gun, and the destruction of a whole garrison of 180 enemy soldiers, "of which a great majority were killed by bayonet, rifle, or artillery fire...or bombed in dugouts. [Sixty] are known to have been bayoneted." 393 The raiders lost one officer killed, and 26 wounded - a low casualty count for the scale of the raid, and a testament to the value of screening patrols in raiding. ${ }^{394}$

The success of raids often depended on patrols, and this was evident as early as 1916, but the relationship between patrollers and raiders was not standardized as a component of the actual assault until January 1918. Patrols had always been vital in gathering intelligence, but they evolved in 1918 to become a vital and integrated element of the raid. ${ }^{395}$ On 2 May the $28^{\text {th }}$ Battalion launched a concerted raid against the German trenches at Arras. Many features of the raid were those established during 1917, but one aspect outlined in the Operation Instructions

\footnotetext{
${ }^{390}$ Ibid.

${ }^{391}$ LAC, RG9, v.3995, 7/5, "Account of a Raid by the Squadrons of Canadian Cavalry Brigade, 'Plan,'” 9 July 1917.

${ }^{392}$ LAC, RG9, v.3995, 7/5, "Account of a Raid by the Squadrons of Canadian Cavalry Brigade, 'Remarks," 9 July 1917.

${ }^{393}$ LAC, RG9, v.3995, 7/5, "Account of a Raid by the Squadrons of Canadian Cavalry Brigade, "Results," 9 July 1917.

${ }^{394}$ Ibid.

${ }^{395}$ Ashworth, 72.
} 
reveals continual tactical development. The orders called for three covering patrols, which "will push out at least 100 yards in advance of each attacking party and cover the assembly. Their action will be to prevent enemy patrols from approaching, to observe any new posts the enemy may have established, and to report...should any change in positions be discovered. These patrols will remain in position until the attacking waves pass through them. ${ }^{, 396}$ These patrols, acting like skirmishers, would scout and ensure that the attack sector was clear of any German patrols or counterattacks on their flanks.

Despite not being primarily focused on engaging the enemy in combat, patrols were still dangerous and terrifying affairs. "In the dark, fear came over me. I began to think of No Man's Land as I had read about it, and as it had been vividly described to me," remembered James Pedley, as he was preparing to go out on a night patrol for the first time. "I began to imagine knifings and shootings, and the horror of being overwhelmed out there between the lines of wire...I grew cold, and shivered...I felt around me the wire and the corpses and the stinking shell holes and (after the killings achieved) came the fatal bayonet thrust, making me wince with imagined pain, and shiver cold as ice..." ${ }^{397}$ Patrols could also act as targets, goading enemy machine gun emplacements into firing and revealing their positions, and intelligence gathered from these patrols aided in the planning and execution of both major raids and offensives.

\footnotetext{
${ }^{396} \mathrm{LAC}$, WD $28^{\text {th }}$ Infantry Battalion, Instructions for Minor Operation, May $1^{\text {st }} 1918$. For another example of patrols acting as skirmishers for raiders, see McWilliams, et al., 144, where on 26 July 1918 , the $46^{\text {th }}$ Battalion raided the German line. The force consisted of two officers and $60 \mathrm{men}$, who were to attack with the object of taking prisoners and destroying enemy posts. They were crucially screened by a patrol of eight skilled scouts who prepared the attack route beforehand, performed vital reconnaissance, and provided flanking cover for the raiders while they were assembling for the attack.

${ }^{397}$ James Pedley, Only This: A War Retrospect 1917-1918. (Graphic Pub., 1927), 148-149. For a German perspective of night patrols, see Junger, 71.
} 
These supporting patrols were extremely intricate operations that required skill, patience, and bravery to carry out successfully, yet they too occasionally met with disaster. ${ }^{398}$ The $13^{\text {th }}$ Battalion was in the line near a point known as Archville Road in the Thelus / Arleux sector, and was tasked on 28-29 June 1917 with determining the positions of enemy units following another Canadian battalion's dummy raid that had occurred earlier that day. ${ }^{399}$ There were reports that the Germans had shelled their own lines during this "demonstration," which indicated that they might have possibility abandoned those trenches. The $13^{\text {th }}$ was tasked with "push[ing] a patrol into the enemy lines to investigate. ${ }^{400}$ Lieutenant J.F. Smith, who was the $13^{\text {th }}$ Battalion's Patrol Officer, along with eight other scouts, left their trenches in the evening and succeeded in sneaking past the German wire and into their trench. Despite a cautious advance, Smith's patrol was ambushed by an enemy strongpoint. ${ }^{401}$ As the patrollers attempted to cross the German wire, they were attacked at point-blank range by German grenades and a machine gun. Perhaps due to the fact that he realized the patrol objectives were at least partially fulfilled, and not wanting to fight the Germans where they had the tactical advantage, Lieutenant Smith immediately gave the order for the party to withdraw back to their own lines. ${ }^{402}$ Staying behind to cover his retreating scouts, Smith was injured and did not make it back to Canadian lines. Despite further aggressive patrols, he was nowhere to be found. Smith was regrettably added to the Battalion's list as MIA, or missing in action, and it was later found that he had been killed. ${ }^{403}$ Patrols were dangerous operations, but their value alongside raiding in minor operations later in the war cannot be ignored.

${ }^{398}$ R.C. Fetherstonhaugh, ed. The $13^{\text {th }}$ Battalion: Royal Highlanders of Canada 1914-1918. (Canada: Royal Highlanders, 1925), 184.

${ }^{399}$ LAC, WD, $13^{\text {th }}$ Infantry Battalion, June 29, 1917.

${ }^{400}$ Featherstonagh, The $13^{\text {th }}$ Battalion, 184.

${ }^{401}$ LAC, WD, $13^{\text {th }}$ Infantry Battalion, June $29,1917$.

${ }^{402}$ Ibid, 185.

${ }^{403}$ Ibid, 185, and Canadian War Graves Commission [CWGC], Casualty Details, Lieutenant Jeffrey Filder Smith, $13^{\text {th }}$ Battalion, (http://www.cwgc.org/search/casualty_details.aspx? casualty=1575916). 


\section{Increasing the Cycle of Violence with "Private Wars:" German Retaliatory Raiding}

Raiding on the Western Front was not a one-way process for the Canadians, for the German Army also participated in an aggressive policy of trench raids. In accordance with the spirit of revenge and retaliation that was prevalent on the Western Front, the Canadians often found themselves on the receiving end of a raid from their German adversaries - usually in direct retaliation for a previous Canadian attack. Just like the Canadian operations, the German raids were sometimes repulsed with little loss, but occasionally the Canadians suffered heavily at the hands of these skilled Sturmtrupp. ${ }^{404}$

The emergence of German raiding troops stems out of the formation of the elite Sturmtrupp, or storm troopers. Other unit formations took on more literal meanings in their names, such as Jagdkommando, or Patrouillentrupp, or hunting commando and raid troop respectively. ${ }^{405}$ These elite squads were primarily concerned with trench raids and attacking across No Man's Land in aggressive patrols. These were specialized assault units, and many were formed in the first half of 1916 by battalion commanders rather than being organized at higher levels. Their primary function was to participate in the attack with "limited objectives," or bite and hold as the allies referred to it, but the Sturmtrupp really found their main employment in counter-raiding the Allied lines in retaliation for raids they had received. ${ }^{406}$

The German raiding parties largely constituted the same arrangement of officers and men as their Canadian enemy. However, what made them different by the second era of raiding was that they had taken the opposite evolutionary route in the personnel selection for raids. Early German raiders were not specialized troops; they were merely men picked that night to go out on the attack. This was different from the Canadians, as their early raiders were "thrusters" and men

\footnotetext{
${ }^{404}$ Gudmundsson, 81 .

${ }^{405}$ Gudmundsson, 80-81.

${ }^{406}$ Ibid, 80. See also Junger, 83-84, for an account of a German Sturmtrupp experiencing an allied raid on their lines.
} 
from elite battalions fighting for reputation and unit honour. For the Germans later in the war, however, many of their raiders were part of the Sturmtrupp elite assault units. For the most part, these men were volunteers, and featured young "thrusters" who invariably developed an aggressive attack spirit that was not in tune with that of the regular line infantry. ${ }^{407}$ In 1918 , the Canadians also developed their own specialized raiding platoons, but these were integrated into the regular line infantry and were less segregated than their German counterparts; they were a sign of the universality of Canadian raiding within routine offensive minor operations.

The German high command was aware of live and let live just as their Allied counterparts were, and also looked to raiding as a means to quell notions of peace on the battlefield. They did this by using imported Jagdkommando units, which were not part of the trench garrison of the area and thus would not feel any kinship with their victims. They also had no reason to fear the escalation of violence caused by raiding, as by the time an Allied counter-raid might be executed on the German lines, the Jagdkommando units were already on their way back to their training grounds behind the lines. ${ }^{408}$ As one would imagine, the Jagdkommando were despised by regular German troops for coming into the line, stirring up the hornet's nest, and fleeing before the retaliation struck, in form of shells, raids, and often both.

Canadian raids and those from their enemy were in a constant state of instigation, retaliation, revenge, and escalation. German raids were usually in retribution for previous Canadian raids. On 26 May 1918 , the $24^{\text {th }}$ Battalion raided the German lines at Mercatel Switch, in the Arras sector. It was a highly successful raid that inflicted many casualties and garnered prisoners. In response to this raid, the Germans immediately attacked the $24^{\text {th }}$ Battalion's front with a severe bombardment. Following that, they executed a counter-raid on the following night.

\footnotetext{
${ }^{407}$ Gudmundsson, 81 .

${ }^{408}$ Ibid, 83.
} 
Their attacking parties were strong, with two squads numbering 50 men each, with a further estimated 200 men in support to take advantage of any openings the assaulting parties might make in the Canadian lines. ${ }^{409}$ Their raid failed, with heavy casualties suffered as the Germans attempted to approach the alert Canadians, who subjected them to heavy small arms fire. The Canadians immediately responded the next day, retaliating against the German counter-raid with another attack to the right of the $24^{\text {th }}$ Battalion's front. It can be assumed that the men of the $24^{\text {th }}$ would have gladly executed the raid themselves if they were not due to have been relieved. ${ }^{410}$ The Germans exacted revenge for that last raid with further bombardments on the Canadian lines, and then yet another raid on 8 June 1918 against the Canadian battalion to the left of the $24^{\text {th }} .411$ The cycle of violence that these events demonstrated left little hope for live and let live to become lodged on that sector of the front.

According to historian Bill Rawling, German raids were fewer in number and usually less sophisticated than their Canadian counterparts. This was because the Germans were in a defensive position strategically and could rely on their superior use of protective firepower and geography to combat the Allied advances. ${ }^{412}$ German raids, in the eyes of many of their Canadian enemy, were not highly regarded. Lieutenant-Colonel D.E. Macintyre of the $28^{\text {th }}$ Battalion offered some insight into the enemy minor operations:

Raids are frequent now. We raid the Germans partly to get information as to what they are doing and what they think we are doing and also to terrorize them and lower their morale. They try to raid us in order to discover what preparations we are making. Their raids, however, are unusually badly managed and more often

\footnotetext{
${ }^{409}$ Fetherstonhaugh, The $24^{\text {th }}$ Battalion, 213-214.

${ }^{410}$ Ibid, 214.

${ }^{411}$ Ibid, 215.

${ }^{412}$ Rawling, Surviving, 51.
} 
than not they left prisoners or dead with us and obtained no information or prisoners for themselves. ${ }^{413}$

This assessment of German raiding was somewhat simplistic, for the enemy did at times raid with great efficiency and sometimes with significant loss to the Canadians. Furthermore, German raids, on occasion, displayed just as much skill, preparation, and tactical sophistication as their Canadian enemy. The Germans became particularly adept at stealth raiding, with small numbers of raiders sneaking in under the Canadian wire undetected and stealing away into the night with prisoners in tow. On 2 December 1917 , the $19^{\text {th }}$ Battalion was attacked by a small raiding party, with one of its sentries snatched. Orders were given to strengthen the line, increase defensive patrols, and thicken defensive barbed wire around sentry posts. ${ }^{414}$ All of these actions took time, detracted from offensive operations, and had an impact on the Canadian soldiers in the line. Even limited raiding put the enemy - in this case the Canadians - on edge.

\section{Combating German Counter-Raiding: Defensive Doctrine and Morale}

The success of a German raid understandably put other Canadian units on high alert for the possibility of future enemy action in their area. "Not being far away from the enemy lines, special attention is being paid to guards. Raids by ourselves and the enemy have been frequent of late," remembered Private Donald Fraser of the $31^{\text {st }}$ Battalion on 25 March 1917. "The $18^{\text {th }}$ Battalion lost several men as prisoners. ${ }^{, 45}$ These raids raised the level of wariness and aggression. Corporal Will Bird of the $42^{\text {nd }}$ Battalion remembered such enemy actions as often adding to the soldiers' exhaustion: "We had heard they were invaded by a raiding party and had lost three men as prisoners...old Jerry had not been on the level. He had made his raid when they

\footnotetext{
${ }^{413}$ LAC, MG30 E241, D.E. Macintyre papers, 13 March 1917, 272.

${ }^{414}$ LAC, RG9, v.3858, 84/16, "Report from G.O.C., $4^{\text {th }}$ Canadian Infantry Brigade," 2 December 1917.

${ }^{415}$ Fraser, 255.
} 
were thoroughly exhausted after a hard night's work...They ain't got no sense of humour or honour. They give you the camel's 'ump.",416

While raiding and patrolling led to heightened anxiety, Lieutenant James Pedley of the $4^{\text {th }}$ Battalion saw firsthand what the Germans could do if the Canadians were not on the alert, "Fritz had raided the night before and had been repulsed without obtaining identification, but several of our men had been killed during the struggle. Their bodies lay scattered around the trench, covered by blanket or ground sheet, toes alone showing. ${ }^{417}$ Much like the Canadians, aggressive German units, either following orders from above or seeking out targets of opportunity, kept a steady stream of patrols in No Man's Land, as well as aggressive minor operations. On 16 June 1917 , for example, the $85^{\text {th }}$ Battalion received a heavy artillery barrage followed by an attempted bombing raid, which they repulsed successfully. Unperturbed by this failure, the Germans attempted the very next night another raid on the same battalion. Again, this attack was repelled, with Lewis guns, snipers, and rifle grenadiers combining to effectively defend the Canadian positions and break up the attack. ${ }^{418}$ Not all German raids were so decisively unsuccessful, however, and Canadians did suffer men killed and captured during enemy raids.

Losing men to a raid was seen as a mark against a unit's honour. Brigadier-General G.S. Tuxford of the $3^{\text {rd }}$ Brigade commented on an official document that described one of his battalion's failure in stopping a German raid: "I wish to protest against the statement in the remarks columns, that the first attempt on November $27^{\text {th }} / 28^{\text {th }}$ was partially successful...under no circumstances had this raid be described as being partially successful. It was not possible to have asked or have expected the Royal Montreal Regiment to do more than they did. I consider [it

\footnotetext{
${ }^{416}$ Bird, 110.

${ }^{417}$ Pedley, 183.

${ }^{418}$ Hayes, 73.
} 
injustice] to the $14^{\text {th }}$ Battalion that a...correction of this report to be made. ${ }^{.419}$ To a unit that saw themselves as elite and hard fighters, the fact that the enemy was able to best them at what was supposedly their own specialty was often a blow to a battalion's pride, and unit honour needed to be restored. Even unsuccessful attempts by the enemy in carrying out minor operations against Canadian positions were seen as "a bit of impudence that could not be tolerated, and retaliation was decided upon," noted a report by the $58^{\text {th }}$ Battalion, just prior to executing a retaliation raid on 5 April 1918 in revenge for the German attack against their position east of Willerval, in the Arleux sector. The $58^{\text {th }}$ Battalion's small 10-man retaliatory raid reportedly killed six of the enemy. ${ }^{420}$

If a Canadian unit was bested by German raiders, it was often viewed as a failure in command and discipline, and sometimes even worse. On 15 December 1916, the $49^{\text {th }}$ Battalion lost two men taken as prisoners to a well-organized German raid. The reaction from the $7^{\text {th }}$ Brigade commander was vehement concerning two sentries who were posted to guard against German attacks: "I am extremely dissatisfied with the conduct of Pte. Johnson and Dixon and unless these men can give some good reason for their failure to open fire whether upon the enemy or for the purpose of alarming the garrison, I think they should be brought to Court Martial. Be good enough to have them at your Headquarters...for examination by me." ${ }^{421}$ In another instance, the $13^{\text {th }}$ Battalion and $16^{\text {th }}$ Battalion were raided by organized and strongly supported German formations in July 1916. They lost 11 killed including a captain, 29 wounded, and an additional man was listed as missing and probably taken prisoner. The Canadian high command reacted strongly to the raid. Major-General Arthur Currie, then commander of the $1^{\text {st }}$ Division, stated in a dispatch to the commander of the $16^{\text {th }}$ Battalion that he considered the

\footnotetext{
${ }^{419}$ LAC, RG9, v.3858, 84/16, despatch "Headquarters, $3{ }^{\text {rd }}$ Canadian Infantry Brigade," 4 December 1917

${ }^{420}$ LAC, RG9, v.4696, 62/5, "Report on Raid by 'B' Company, $58^{\text {th }}$ Cdn. Inf. Bn.," 5 April 1918.

${ }^{421}$ LAC, RG9, v.4154, 8/9, dispatch " $7^{\text {th }}$ Canadian Infantry Brigade, To: $49^{\text {th }}$ Battalion," 15 December 1916
} 
conduct of the captain in charge and the sentries to be insufficient, and they should be charged with neglecting their duty. He continued his recriminations by stating, "The whole affair is a serious reflection on the training and discipline of the Battalion; it shows an indifference to the teaching of the War and a lack of appreciation of the responsibilities of officers, which I will not tolerate." ${ }^{422}$ To Canadian commanders, it was unacceptable for their formations to be raided and suffer losses at the hands of their enemy. Such incidents were seen as serious marks against the unit's honour and were pursued aggressively by commanders.

In the winter of 1917 , German raids became more frequent, which was in direct reaction to the increase in Canadian raids during the same period. These more frequent German raids prompted BEF high command to issue guidelines to aid in the combating of these enterprises. In a First Army despatch to all four Canadian divisions, it was noted that "It is obvious that the Germans are trying every means in their power to obtain identifications from the Corps so as to locate the Divisions. It is therefore of extreme importance to prevent as far as possible their achieving this result." ${ }^{, 423}$ The despatch emphasized that the enemy had attempted a great many raids in the early hours of the morning and units were to be prepared to ambush German raids with defensive patrols. ${ }^{424} \mathrm{~A}$ report by Brigadier-General Edmund Ironside sent to all four divisions noted, "The enemy has been continuously active in raiding...the majority of these raids have been repulsed with loss to the enemy, but hostile activity appears to be on the increase and the Corps Commander is anxious that this should be checked at once...Strong and active patrolling of No Man's Land must be organized...Plans for raids against the enemy will be

\footnotetext{
${ }^{422}$ LAC, RG9, v.3858, 84/16, "1 1 st Canadian Division, G.O.C., $3^{\text {rd }}$ Canadian Infantry Brigade," $19^{\text {th }}$ July 1916.

${ }^{423}$ LAC, RG9, v.3858, 84/16, "Canadian Corps, G.561," 15 March 1917.

${ }^{424}$ Ibid.
} 
worked out and executed at suitable points on the front." ${ }^{425}$ The cycle of violence in minor operations fed itself.

The Allied artillery gunners were always on alert to support their infantry brethren in the event of a German raid. E.G. Black, a Canadian artilleryman, recounted a time when "a signaller stuck his head out of the control-pit shouting, 'SOS'. I was beside the gun in less time than it takes to write the words. The gun was loaded and laid on our SOS line, and all I had to do was pull the firing lever to put an air-burst just in front of our trench where raiders might be approaching it...It is the unexpected and unknown that terrifies. ${ }^{, 426}$ Close support of artillery, and their timely response to Canadian flare-signal requests for S.O.S. barrages, were important means of thwarting a potential German raid. These S.O.S. barrages consisted of "of an intense pre-planned squall of shells designed to catch an attacker in No Man's Land, before he could reach the defender's front trench. A good S.O.S. response could smother him with such an impenetrable wall of bursting shrapnel or high explosive that he would be entirely obliterated, in every horrific sense of that particular term." ${ }^{427}$ The fast response of the gunners in protecting their infantry from potential German raids was well appreciated by the front line troops, as Corporal Bird recalled "in the morning...[t]he enemy tried to raid trenches near Hill 70 and we saw our S.O.S. go up. The response of our artillery was heartening. It did not seem an instant before a barrage was falling on the German lines." ${ }^{428}$

That close cooperation between infantry and their supporting arms, instigated by the early trench raids and slowly improved upon through successive minor operations, would eventually pay great dividends in major battles. The combining of firepower and small-unit tactics into an

\footnotetext{
${ }^{425}$ LAC, RG9, v.4017, 35/14, "Canadian Corps, G.14/25-7," 2 December 1917.

${ }^{426}$ Ernest Black, I Want One Volunteer. (Toronto: Ryerson, 1965), 162-163.

${ }^{427}$ Griffith, 41.

${ }^{428}$ Bird, 111-112.
} 
offensive doctrine of "fire and movement" demonstrated its effectiveness at Vimy Ridge, but it really made a crucial difference in subsequent major operations - especially when open warfare was restored to the Western Front during the Hundred Days. However, tactics unfortunately did not compensate for poor strategy, and even the well-oiled Canadian Corps was unprepared for what was to follow in the fall: the muddy hell known as Passchendaele. This environment proved to be a serious challenge to the Canadian infantry who took over from British units in the fall, after the British offensives had ground to a halt. The muddy and broken terrain around Passchendaele made trench raiding almost impossible. ${ }^{429}$ But the awful terrain did not keep the Canadians cowering in their flooded trenches and craters. Minor operations were still carried out in the form of dangerous reconnaissance patrols in No Man's Land. Passchendaele was won with raw courage, "sheer unadulterated bravery," including instances of lone infantrymen charging pillboxes and machine gun nests, and bombing them into submission. ${ }^{430}$ Passchendaele was taken, but at the terrible cost of nearly 16,000 Canadian casualties, and in its wake left the Corps' morale battered as it prepared for its final winter of the war.

\section{The Final Hunting Season: Raiding in the Winter of 1917-1918}

After the Passchendaele campaign was shut down in mid November 1917, the Canadians did not rest to await the next big battle. As winter came, another season of raiding began in lieu of any large-scale battles that would not emerge in the Western Front until the German offensives in the spring of 1918. The Canadian minor operations over the winter of 1917-1918 were carried out during a period of reorganization for the Canadian troops. They were still reeling from the terrible slaughter on the Passchendaele front, and needed time to recuperate and reorganize. This period also saw a Canadian infantry that was markedly different than the one

\footnotetext{
${ }^{429}$ Rawling, Surviving, 158.

${ }^{430}$ Cook, Shock Troops, 322-323. For further discussion on patrols and their importance at Passchendaele, see Shackleton, 174.
} 
that fought over roughly the same ground two years before. As 1918 dawned, the Canadians were a battle-hardened and professionalized infantry formation. ${ }^{431}$ Part of that professionalism was because of the Canadians' ownership of No Man's Land, due in large part to their aggressive raiding policy, which allowed them an area to hone and perfect their skills, although, as we have seen, that ownership was occasionally tested by German counter-raids.

As part of the Canadian campaign of raiding, on 17 January 1918 , the $46^{\text {th }}$ Battalion attempted to send a "strong battle patrol" across the muddy morass of No Man's Land and through the enemy wire, but it was caught in the open and suffered casualties. ${ }^{432}$ The $46^{\text {th }}$ Battalion recovered from this minor setback with a larger raid in February. The raid was successful in reaching its objectives and in capturing four German prisoners, but the documentation of the raid provides some insight into the murky world of raiding. Colonel H.J. Dawson gave brigade headquarters an account of the raid, but it was rewritten by a brigade staff officer, before being sent to divisional headquarters. The initial report observed that, while the attack was a success, the supporting mortar barrage had failed, with rounds falling short and causing friendly causalities. However, the rewritten brigade report ignored these facts and stated that "Our barrage was very good." The Canadian casualties were also downplayed. In the initial report, it stated that there were "two men missing, one severely wounded, and two slightly wounded," but this was later summarized simply as "light" casualties. When the raid report finally filtered its way up, all the way to British General Headquarters, General Haig's staff published an account in a newspaper with a claim that "Our raiding party returned to our lines

\footnotetext{
${ }^{431}$ Tim Cook, "Bloody Victory: The Canadian Corps in the Hundred Days," in 1918: Year of Victory: The End of the Great War and the Shaping of History. Ashley Etkins, ed. (Auckland: Exile Pub. Ltd., 2010), 163.

${ }_{432}$ J.L McWilliams and R.J. Steel. Suicide Battalion: $46^{\text {th }}$ South Saskatchewan. (Edmonton: Hurtig Publishers, 1978), 131.
} 
without loss. ${ }^{, 433}$ Although that was technically true, no raiders were killed in action during the attack, the wording was extremely misleading. This rewriting of reports is troubling, in that it suggests that at least some of the lessons from raiding were perverted in the name of putting forward the best face to higher formations. While there does not appear to be much evidence in the records, it is, of course, a difficult circumstance to locate, especially if the original report was destroyed.

Even with the advent of effective battle raids, the Canadians continued also to practice traditional stealth raiding into 1918. Stealth raids were still the most efficient way of gathering intelligence information from the enemy. The $27^{\text {th }}$ Battalion raided on $18-19$ February 1918 at Metal trench, in the Avion sector. ${ }^{434}$ Thorough reconnaissance was done in the weeks prior to the raid, revealing that at trench grid N.33.d the enemy were not alert, yet always occupying their forward posts. ${ }^{435}$ Due to this it was decided that a small stealth raid would be best to procure intelligence information, and the raid would consist of only 49 men. ${ }^{436}$ Despite the small scale of the raid, practicing and preparation for the raid was thorough, with a set of practice trenches set up behind the lines so that the raiders would all be familiar with their role in the attack. In the days before the raid, wire cutting was done by battalion trench mortars, but in order to mask the point of attack to the enemy the mortars cut the wire at numerous points along the enemy front. On 17 February, patrols discovered that the Germans were shielding these gaps in the wire with their own strong patrols, so the raid was altered on the morning of 18 February to include a crash bombardment of shrapnel shells to support the raiders. ${ }^{437}$

\footnotetext{
${ }^{433}$ Ibid, 132-133

${ }^{434}$ LAC, RG9, v.4148, 14/15, "Report on Small Raid," 19 February 1918.

${ }^{435}$ Ibid.

${ }^{436}$ LAC, WD, $27^{\text {th }}$ Infantry Battalion, 19 February 1918.

${ }^{437}$ LAC, RG9, v.4148, 14/15, "Report on Small Raid," 19 February 1918.
} 
At zero hour, 0200 , the raiders stormed the enemy lines following their shrapnel barrage, which then transitioned to a box barrage to cover the assault. They were also supported by Lewis gun positions and rifle grenadiers as covering parties. Splitting into two groups, the Canadian soldiers assaulted down the enemy trenches. As they encountered enemy posts, the raiders attacked with grenades and bayonets, taking prisoner any enemy who survived their onslaught. At 0216 , the raiders quickly withdrew back to their own lines, covered by the supporting parties equipped with rifle grenades and Lewis guns. The raiders captured six prisoners, inflicted a number of casualties, and suffered no casualties of their own. ${ }^{438}$ This raid demonstrated crucially the emerging flexibility of Canadian minor operations, where they adapted the parameters of the raid to new intelligence information to provide the raiders with the best chance of accomplishing their objectives.

Despite the efficient combat system that had been built up over the latter half of 1917 , Canadian raids still ended in failure. On 7 January 1918 , for example, the $4^{\text {th }}$ C.M.R. was ordered to attack the enemy trenches with the objective of destroying machine guns, dugouts, and securing prisoners. Thirty raiders were detailed to carry out the raid, and went to the rear to practice and train. ${ }^{439}$ As part of the initial scouting process, the area was investigated thoroughly by battalion scouts, who discovered thick wire at the enemy trenches. This wire was thus to be destroyed with both hand-cutters and with a bangalore torpedo explosive. On the night of the raid, the raiders were prepared to execute the attack, but the wire was too thick to be cut, with raiders working feverishly for hours in the dark of No Man's Land. Nor did the bangalore detonate. One man even tried to valiantly go forward and extricate the bangalore to fix it, but got entangled in the wire and alerted the German sentries. Grenades began to explode around the

\footnotetext{
${ }^{438} \mathrm{LAC}, \mathrm{WD}, 27^{\text {th }}$ Infantry Battalion, 19 February 1918.

${ }^{439}$ Bennett, 93.
} 
raiding party, who were forced to retreat. ${ }^{440}$ The raiders had squandered their window of opportunity. Even minor incidents - the malfunction of a weapon or the alerting of a sentry could ruin a raid. The raiders in this case were fortunate to retire without casualties.

\section{Raiding Perfected: 58 ${ }^{\text {th }}$ Battalion "Commotion Sap" Raid, 13 January 1918}

As the Canadians continued to raid in the winter as part of the strategy of attriting the enemy forces in between the big battles, they steadily made improvements to their tactics, logistics, and command and control in minor operations. On 13 January 1918 , the $58^{\text {th }}$ Battalion raided "Commotion Sap," a strongpoint near St. Emile, Lens sector. The officer who volunteered to command the raid, Lieutenant Arnold Jucksch, spent five weeks prior to the raid patrolling No Man's Land and reconnoitring the area to be raided, noting every detail. This reconnaissance aided in recreating exact replicas of enemy trenches behind the lines, as well as accurate reports of enemy patrols, sentry posts, routine, and machine gun firing arcs. ${ }^{441}$ The raid was planned to gather intelligence, for "abnormal activity having been recently shown by the enemy in St. Emile Section, identification was very much desired...Commotion Sap...was settled upon as the most likely spot for a real surprise." ${ }^{442}$ The 42 raiders were divided into 6 sections; each assault section featured bayonet men, bombers, and dedicated rifle-grenadiers. Two sections were equipped almost entirely with rifle grenades, to act as mobile support sections to attack enemy strongpoints and to provide cover for the assault sections. Support was given by Stokes mortars and machine gun teams providing barrages on the suspected enemy reinforcement points, and an ammonal tube was used to create a path in the enemy wire, and also served as the signal for the start of the raid. The raiders practiced on the recreated trench systems in daylight and at night, and even simulated the attack with live ammunition and an actually ammonal tube explosion to

\footnotetext{
${ }^{440}$ Ibid.

${ }^{441}$ Shackleton, 202-203.

${ }^{442}$ LAC, RG9, v.4154, 8/8, "Report on Raid, 'Information," 13 January 1918.
} 
add realism. At 1800 on 13 January, zero hour, the ammonal tube exploded and the raiders began their swift assault. ${ }^{443}$

Everything unfolded with textbook precision, with the raiders attacking with such swiftness that the enemy was given no time to organize a defence. The raiders used grenades and rifle grenades to deadly effect, bombing German positions as they stormed down their planned assault routes in the enemy trenches. "The objectives allotted to each section were all gained," noted the official after-action report. ${ }^{444}$ After attaining their objectives and securing prisoners, the raiders quickly withdrew and were back in their own trenches in a little more than an hour. ${ }^{445}$ The official report commented that "No.1 section encountered particularly strenuous opposition and it was only through...the initiative displayed by all ranks that they were able to make good their objective...Absence of casualties was due in great measure to every man knowing his special duty and carrying it out with steadiness, quickness and determination." ${ }^{, 446}$

The raid was a tremendous success, arguably one of the most efficiently executed raids since the Petit Douve raid in November 1915, considering the number of troops committed, the casualties sustained, and the damage dealt during the raid. The raiders succeeded in capturing 11 prisoners, and an estimated 16 casualties were caused to the enemy. The raiders suffered no men killed or wounded $-\mathrm{a}$ true testament to the level of preparation and planning that went into the raid. Major-General Lewis Lipsett, commander of the $3^{\text {rd }}$ Division, surmised, "I think we are justified in considering it one of the most successful of the small raids carried out on the front." He also concluded that "the 23 Mills rifle grenade deserves consideration. In my opinion, the training in the use of this grenade, which enables us to out-range the German stick and egg

\footnotetext{
${ }^{443}$ Shackleton, 203.

${ }^{444}$ LAC, RG9, v.4154, 8/8, "Report on Raid, 'Objectives,"” 13 January 1918.

${ }^{445}$ Schackleton, 207, and LAC. RG9, v.4696, 62/4, "Notes on Raid," 14 January 1918.

${ }^{446}$ LAC, RG9, v.4154, 8/8, "Report on Raid, "Casualties," 13 January 1918.
} 
grenades, is of great importance." ${ }^{447}$ In training for future raids, staff officers used the 13 January Commotion Sap raid as a model of how to carry out such an operation. ${ }^{448}$ The combination of detailed reconnaissance, thorough planning and preparation, effective use of rifle grenades, and leadership from junior officers all combined to demonstrate the pinnacle of Canadian minor operations tactics prior to the Hundred Days.

\section{An Alternative to Raiding: ANZAC Peaceful Penetration}

In the fighting on the Western Front, Canadians certainly were not the only military formation to participate in raiding, and each national force adapted a system of minor operations that best suited its approach to trench warfare. The Germans, as discussed above, adopted their raiding strategy to focus less on destruction of the enemy and dugouts, although that was achieved, but rather more on stealth raids, supported by artillery and trench mortars, to secure identifications, intelligence information, and prisoners. Although all armies adapted their own individual approaches to raiding, the Australians, or ANZAC Corps, was particularly noteworthy for their approach to minor offensive operations on the Western Front.

The Australians did not begin to fight on the Western Front until the spring of 1916, for their war began with the ill-fated invasion at Gallipoli in 1915. When they did arrive on the European battlefield, they were quickly introduced to a "sharper incident of regular trench warfare," like on the night of 5 May 1916, when the Germans raided the new Australian units at the Bridoux Salient, south of Messines. ${ }^{449}$ The Australians lost men taken prisoner, a machine gun, and two top-secret Stokes trench mortars.

\footnotetext{
${ }^{447}$ LAC, RG9, v.4053, 24/6, dispatch, Major-General L.J. Lipsett "C.111, $3^{\text {rd }}$ Canadian Division, Canadian Corps," 24 January 1918.

${ }^{448}$ Shackleton, 207.

${ }^{449}$ Charles Bean, Anzac to Amiens. (Canberra: Australian War Memorial Press, 1946), 207.
} 
The Australians quickly recovered and learned from their setback. They soon instituted an aggressive policy of trench raiding. For example, a Second Army "Program of Proposed Operations," dated 15 June 1916 , contained eight raids within a 10 day period by the $1^{\text {st }}$ ANZAC Corps. ${ }^{450}$ Similarly, the ANZAC raiders were equally busy later in the month, with a raid being pulled off on the night of 25-26 June 1916 southeast of a point called Bois Grenier. This attack succeeded in entering the enemy trench, killing several Germans, and withdrawing with four prisoners in tow. On the same night, another ANZAC unit raided east of Pont Ballot further down the line from the other raid. These raiders also were successful, killing several Germans, blowing up a mine shaft, and taking nine prisoners. The two raids accounted for an estimated 60 enemy casualties, while suffering 13 wounded and one killed. ${ }^{451}$ The ANZAC Corps became adept at trench raiding, much like the Canadians, but as the war progressed into 1918 their approach to minor operations differed significantly from their fellow colonials.

In 1918, the Australians began to practice a form of offensive operations that they termed "peaceful penetration." 452 This tactic was an evolution of the aggressive patrol, much like the raid. Where it differed from raiding was that it focused on slowly capturing enemy outpost territory through successive minor raids, with the attackers holding the ground that they had overrun. This tactic emerged in reaction to the German defensive tactics that had created a deeper "checkerboard" stratified defence, with a loosely held front line screened by a series of outposts. $^{453}$ These forward outposts made for good targets. Historian C.E.W. Bean described an engagement in the spring of 1918 :

\footnotetext{
${ }^{450}$ LAC, RG9, v.3858, 82/3, "G.H.Q. Second Army Program of Proposed Operations," 15 June 1916.

${ }^{451}$ LAC, RG9, v.3858, 82/3, "Summery of Raids Second Army," 30 June 1916.

452 Bean, 445.

${ }^{453}$ Bean, 444.
} 
The Australians and New Zealanders...refused to leave the opposing Germans alone... Wherever the ground gave any freedom of movement, these Dominion troops began to pester the enemy, trying to waylay his patrols and cut out his posts - to wage....a ceaseless 'private war'...This was supplemented by a series of set attacks, generally planned to capture sections of the new front line from the Germans before they had fully established it. Often, when the Germans tried to bridge with new trenches the gaps so made, these new trenches would be successively wrenched from them. ${ }^{454}$

Whereas the Canadians had adopted a policy of "butcher and bolt," the Australians steadily exerted pressure, snuffing out strongpoints, eating into the German buffer zone, wreaking havoc with German morale and their entire defensive grid. A German report of an instance of peaceful penetration explains the frustration it caused to the enemy: "At 11 a.m. on July $8^{\text {th }}$ the enemy penetrated the forward zone...He occupied the trench where our most advanced outpost lay and apparently captured the occupants, comprising fifteen men. The larger part of the forward zone has been lost. ${ }^{.455}$ The Germans attempted to constantly change defensive tactics to combat the incessant "nibbling" of their front posts, to no avail. ${ }^{456}$

The Australians were not the only formation participating in peaceful penetration on the Western Front. Other Allied forces attempted to incorporate this tactic into their minor operations arsenal, and that included the Canadian Corps. For example, Currie's raiders took the idea of peaceful penetration and utilized it to good effect on the outskirts of Lens in the summer of 1917. In the suburbs of Mericourt, in the Avion sector, the Canadian battalions participated in

\footnotetext{
${ }^{454}$ Bean, 445.

${ }^{455}$ Bean, 456.

${ }^{456}$ Ibid.
} 
a policy of constantly advancing patrols to "keep nibbling into the enemy front towards Lens.",457 The terrain, broken with craters and rubble, provided the Canadian scouts with a haven to pursue an aggressive patrolling policy with relative impunity. The $85^{\text {th }}$ Battalion demonstrated this tactic by continually patrolling, taking and consolidating forward posts, and then linking them together with adjacent posts and communication saps until they were within 10 feet of the German front line wire. ${ }^{458}$ They had effectively reduced No Man's Land down to nothing, forcing the Germans back deeper into the suburbs of Lens.

While the Canadians occasionally engaged in this peaceful penetration, and usually when the terrain dictated it to their advantage, the Australians seemed to completely abandon regular trench raiding by 1918 , focusing on their evolving minor operations of closing with the enemy and slowly incorporating No Man's Land into their front lines. ${ }^{459}$ Whereas the Canadians' assault raids centred on inflicting casualties, capturing prisoners, and destroying trench systems in preparation for set-piece battles that would eventually occupy the same blood-stained ground, the Australians instead focused on the ground itself. They inflicted fewer casualties, but still discomfited the enemy. The Australian peaceful penetration was not better or worse than the Canadian "smash and grab" trench raids, it was just a different means to the same end: attriting morale and strength, pushing the enemy from prepared defences, and destabilizing his forces so that he would be weakened for the large-scale set-piece battles.

\footnotetext{
${ }^{457}$ Joseph Hayes, The Eighty-Fifth in France and Flanders. (Halifax: Royal Print \& Litho Ltd., 1920), 81-82.

${ }^{458}$ Ibid, 81.

${ }^{459}$ Bean, 456-459. A clear indication of this trend is that after peaceful penetration was established in 1918 , there are no further reports mentioned by C.E.W. Bean or in Canadian records of actual combat raids being undertaken by Australian units. A possible explanation for this is that peaceful penetration proved to be so successful for the Australians that they saw no need to change their tactics to a more risky one like trench raiding in order to attain the same goal.
} 


\section{Raiding and Prisoners of War}

One of the primary intelligence aims of Canadian raids was to capture prisoners of war. ${ }^{460}$ This was a dangerous task, but those who endeavoured to raid and bring back a valuable prisoner received incentives for their efforts. Lieutenant James Pedley of the $4^{\text {th }}$ Battalion remembered an instance where "Brigade wind was still up and there was great hope of getting a prisoner. 'Bring me in a Boche, Jimmy,' said Stagg, 'and you'll be in London next week.' That

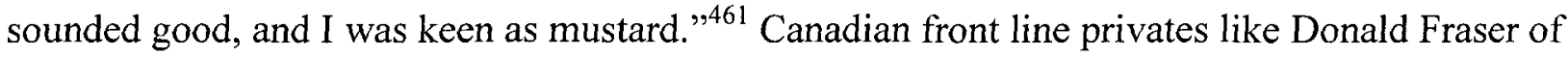
the $31^{\text {st }}$ Battalion were told, "Much valuable information is being obtained from prisoners captured during recent raids. Our command now know who are their opponents, where the enemy billets are, what mining is going on, etc. Confirmation is being obtained from photographs taken from planes. ${ }^{\not 62}$ These intelligence details could serve to augment future operations, revealing the enemy's state of readiness, their morale, their weaponry, scouting routines, or whether they were aggressive formations or not. ${ }^{463}$ No detail was too small; as Cuthbert Mathews, who fought from 1916 until his wounding in August 1918, recalled: "The prisoners [were] all either old men or boys [there] wasn't a decent sized man amongst them. But they were all well clothed and equipped. [They said] they had been getting plenty to eat." Prisoners were also a sign of a success on the battlefield. Battalions competed to pull off more and more daring raids while capturing as many prisoners as they could. Howard Thorburn of the Royal Field Artillery recounted: "We had a fight the other day and it sure was a good one...We'd absolutely flattened his trenches and over 200 were killed and 78 prisoners were taken. The Canadians hold the record for a raid having got 125 prisoners... We had pretty heavy

\footnotetext{
${ }^{460}$ Cook, At the Sharp End, 299. See also Jenkins, "Winning Trench Warfare," 143.

${ }^{461}$ Pedley, 169.

${ }^{462}$ Fraser, 188.

${ }^{463}$ Jenkins, "Winning Trench Warfare," 145.

${ }^{464}$ CLIP, Cuthbert Mathews, letter, June 11917.
} 
casualties however, but it was worth it." ${ }^{465}$ This inter-unit competition served to make risk-taking and experimentation in raids commonplace, but it also allowed for the harnessing of new tactics and weapons that would aid the Canadians in forthcoming battles. The failure to procure prisoners, however, could be seen as a mark against a unit's reputation. Lieutenant James Pedley remembered the aftermath of a failed raid: "the cruel truth was hard to face - eleven casualties, no identification, and a garbled message to brigade which had made matters even worse...now, to explain the exact meaning of the garbled despatch would mean putting emphasis on the very incident which was the battalion's mockery and shame."

Stealth raids were the preferred method of prisoner capture, as they allowed for a greater chance of surprising the enemy. In order to achieve this, some intrepid raiders embraced creative ways of camouflaging themselves. Private Fraser recalled: "I heard the $27^{\text {th }}$ Battalion made another raid, disguising themselves this time with grass coverings. They were more fortunate than before, obtaining a prisoner..." ${ }^{467}$ They had resorted to this camouflage because, as Fraser noted, they had previously experienced difficulty catching the enemy while they were vulnerable: "The $27^{\text {th }}$ Battalion went over on a raid. They had no casualties and captured no prisoners. They got into the enemy firing line but found no Heinies...It looks as if he moves his men back and forward to escape casualties." $468 \mathrm{He}$ continued with his assessment of the core aspects of stealth raiding. "Success at the expense of a minimum of risk appeared to be the cardinal point to work on...our Scouts should ascertain the easiest course to his trench, and by stealth we would take him by surprise, rushing back with the necessary prisoners. This plan

\footnotetext{
${ }^{465}$ CLIP, Howard Thorburn, letter, August 121917.

${ }^{466}$ Pedley, 266-267.

${ }^{467}$ Fraser, 188-189.

${ }^{468}$ Fraser, 256.
} 
would entail a considerable amount of luck and dexterity to be pulled off successfully. Any other scheme with a limited number of men appeared hopeless and suicidal."

Although prisoners were highly prized, the process of capturing them and keeping them alive on the battlefield was difficult. Furthermore, there was an ambiguous grey area between deadly combat and an enemy's surrender. Historian Tim Cook has concluded that surrendering on the Western Front was one of the most dangerous acts a soldier could undertake on the battlefield. ${ }^{470}$ This was evident when an enemy soldier laid down his arms to a trench raider. To do so was to surrender to a hardened killer, who was in the enemy trench to kill and destroy anything he encountered. The rules of war, which stipulated that surrendering soldier should not be harmed, were stretched or completely ignored while trench raiders attacked, and the raiders were seldom censured for "forceful behaviour," as the whole point of raids was to attack and shock the enemy by killing or maiming them, and dragging a few back as prisoners. ${ }^{471}$

In this murky moral environment, lines between battle and killing were often blurred. Private John Becker of the $75^{\text {th }}$ Battalion remembered one such grisly episode while raiding the enemy trenches with an unnamed fellow raider: "This German was lying on his back on the floor of the trench, his rifle not far away...His hands immediately went to his breast...and he murmured 'Kamerad, Kamerad.' I said to X 'Here's a prisoner for us.' He looked at the prostrate enemy, uttered an oath, kicked him as he lay looking at us, then pointed his rifle and shot him through the heart." Private Becker was surprised by the action but did not condemn it, writing that killing of prisoners - despite their value - was not uncommon, "There was no doubt shooting of helpless and wounded by both sides during the war - there were many evidences of it after every

\footnotetext{
${ }^{469}$ Fraser 185 .

${ }^{470}$ Tim Cook, "The Politics of Surrender: Canadian Soldiers and the Killing of Prisoners in the Great War," The Journal of Military History, Vol. 70, No. 3 (Jul., 2006), 638.

${ }^{471}$ Ibid, 643.
} 
action...we were told prior to this raid that only 5 or 6 prisoners were wanted - that we were to annihilate the rest." 472

Trench raiders, while in the enemy lines, were always fighting against the enemy, but also against the clock. If they waited too long in the German trenches they would be extremely vulnerable to counterattacks by a larger force. Taking too many prisoners was one way that raiders were slowed down, and could put the whole raid in jeopardy. Hard decisions were thus made. On 29 July 1918 , the $87^{\text {th }}$ Battalion raided the enemy trenches. The official report described the attack, stating "The raiding party...met with considerable opposition. They found...several wounded enemy. This party killed 17 of the enemy and took one prisoner." The report then continued, "The enemy everywhere showed fight, and all the prisoners taken, with the exception of two, had to be killed as they refused to come along. The enemy trenches were in bad shape and progress was slow." ${ }^{, 47}$ It is perhaps surprising that an official report was so open about these executions, but that is another indication that such acts were frequent and, as seen by many soldiers, unavoidable in the context of the operation. But prisoners remained extremely valuable, so this often militated against the coldblooded murder of all enemy troops. More prisoners taken usually meant more glory for the raiders. Nonetheless, it is clear that there were no easy answers in the chaos and confusion of a raid.

\section{Professionalism Attained: Spring and Summer Raiding in 1918}

Raiding continued to be practiced aggressively as the Canadians moved into the spring of 1918. While the principles of raiding were laid down, the soldiers at the front continued to tinker and experiment. Even as artillery was deemed nearly essential in every raid, it also had the drawback of alerting the enemy to an attack. One risky method of preserving surprise was to do

\footnotetext{
${ }^{472}$ Becker, 85

${ }^{473}$ LAC, RG9, v.3858, 82/8, "Minor Operations Report: $11^{\text {th }}$ Canadian Infantry Brigade," 29 July 1918
} 
away with the preparatory bombardment. This surprise tactic was employed by the $58^{\text {th }}$ Battalion on 13 January 1918, as discussed above, with the raiders succeeding in their objective of securing prisoners and information. A complicated crash barrage of trench mortars and rifle grenades had been used instead of artillery, with the hurricane barrage unleashed at the moment of the assault. ${ }^{474}$ This allowed the raiders to surprise the enemy by not telegraphing their intentions with an artillery bombardment, but still being able to lay concentrated firepower on the enemy's strongpoints and machine guns. The third era of trench raiding saw the infantry forming into self-sufficient assault units, capable of forging ahead on the battlefield and successfully assaulting and overcoming enemy strongpoints without being reliant on heavy artillery.

On 26 May 1918, the $24^{\text {th }}$ Battalion executed a large raid on the German lines near Mercatel, in the Arras sector. ${ }^{475}$ This raid demonstrated the efficiency level the Canadians had attained by the spring of 1918 , as it was conceptualized, planned and executed in a matter of only a few days. Thorough scouting was completed in the three nights before the raid, where opportunities for breaches in the enemy wire were marked along with detailed reconnaissance of the terrain near the front line and in No Man's Land. Officers studied the routes and laid down the axis of advance. Two attacking parties of 15 men each were detailed to assault the trenches, and they were protected by two covering squads equipped with rifle grenades and Lewis guns. The raiders succeeded, despite unforeseen difficulties with previously undiscovered German wire, in crossing to their jumping off point undetected. With no preparatory barrage, at 0016 the raiders sprang into the German trenches, immediately shooting two German sentries. They

\footnotetext{
${ }^{474}$ Rawling, Surviving, 172, and LAC, RG9, v.4053, 24/6, "Report on Raid carried out by $58^{\text {th }}$ Battalion," 13 January 1918. Note that Rawling states the raid took place on 21 January, when in fact the $58^{\text {th }}$ Battalion raided on 13 January, and it was the report that was filed on the $21^{\text {st }}$.

${ }^{475}$ Fetherstonhaugh, The $24^{\text {th }}$ Battalion, 212-231.
} 
attacked another post, killing one enemy and taking two prisoners, and then proceeded to assault further down the enemy trenches. In the preceding chaotic minutes, they encountered a further garrison of 15 Germans, who were all killed. With their allotted time in the enemy trenches running out, the raiders retreated with two prisoners, having suffered only two slightly wounded. ${ }^{476}$ The raid was a complete success and also served to demonstrate the ability of infantry to overcome strong enemy positions without outside support. These tactics would pay dividends in the frenzied battles of the Hundred Days, where the infantry would be fighting in constant battle patrols, pushing their way forward using advanced tactics to assault and overcome enemy resistance.

One key development in Canadian minor operations during the spring of 1918 was that every company had one platoon that was to consist of raiding specialists. This was a significant devotion of resources to raiding, considering there were only four companies in 1000-men strong battalions, and each one was about 200 men. The four platoons in a company numbered about 40 strong at this point on the war. These embedded specialists were different than the infantry structure of 1915-1917 when raid leaders either asked for volunteers or selected men they saw as most fit for the raid. ${ }^{477}$ With the institution of raiding increasingly professionalized, as with bombing, scouting, and machine gun specialization, raiding finally in 1918 had become a standard aspect of every Canadian battalion.

Raiding continued to evolve in the summer of 1918 , as the allies prepared to strategically counterattack the German forces, which had, at that point, been attacking on the Western Front for several months and had suffered close to a million casualties. ${ }^{478}$ The $2{ }^{\text {nd }}$ Division

\footnotetext{
${ }^{476}$ Ibid.

${ }^{477}$ Rawling, Surviving, 174.

${ }^{478}$ Robert Foley, "From Victory to Defeat: The German army in 1918," in 1918: Year of Victory: The End of the Great War and the Shaping of History. Ashley Etkins, ed. (Auckland: Exile Pub. Ltd., 2010), 87. See also John
} 
experimented with, and developed a reputation for, carrying off many deep raids. These raids, also termed battle raids, did not stop after the initial surge into the enemy lines, but continued farther and farther into German reserve lines - sowing confusion and disorder amongst reinforcements and garrison troops who were not expecting such penetrations. ${ }^{479}$ First seen in late 1916 in raids such as the Lille Road raid by the $1^{\text {st }}$ C.M.R., battle raids continued to be one of the most effective tactics raiders employed against the enemy.

\section{Evolving Full Circle: Raiding in the Hundred Days}

With three years of training and preparation against the static German trench system, the war changed abruptly in late 1918 , when mobility was restored to the battlefield. This period, known as the Hundred Days offensives, and spanning from August to November 1918, was not conducive to traditional raiding. The Hundred Days saw a series of major set-piece battles at Amiens, Canal du Nord, the Drocourt-Queant Line, Valenciennes, and Mons, which were characterized by the combined arms approach to warfare. ${ }^{480}$ With these large battles far more frequent than in previous years, where there could be months before major engagements, there is evidence of Canadians engaged in both patrols and raids, but these were often smaller affairs, and usually directed against enemy posts and forward parties. Sergeant Charles Savage of the $5^{\text {th }}$ C.M.R. remembered one instance at the Canal du Nord in late September 1918 where the Canadians were on the receiving end of these minor raids: "They had placed one post almost on the canal bank...and since it was in a rather exposed position they had put fifteen or twenty men in it...The Germans apparently located this post, no very difficult job on a still night, and made a

\footnotetext{
Toland, No Man's Land: 1918, The Last Year of the Great War. (New York: Doubleday \& Company, Ltd., 1980), 299. For an analysis of the significance of the Spring Offensives see also Paul Davis, 100 Decisive Battles: From Ancient Times to the Present - The World's Most Major Battles and How they Shaped History. (New York: Oxford University Press, 1999), 364-367.

${ }^{479}$ Cook, Shock Troops, 400.

${ }^{480}$ Schreiber, 119.
} 
very good plan for putting it out of action. They assembled forty or fifty men with ladders in the canal and at about two PM of a hot day they all appeared suddenly on our edge of the canal. Each one threw three or four bombs into the unfortunate post. Then they jumped back into the canal. And that was that..." ${ }^{481}$ These were essentially minor raids to harass and kill the enemy, but on a very small scale and never of the depth or complexity of the intricate operations that took place in the early summer of 1918.

Traditional raiding, as a product of a static battlefield, was not suited to the open field warfare during the final months of the war. The offensive fronts were simply changing too quickly for raiding to be of any use, since the Germans were in constant retreat. ${ }^{482}$ Yet pressure had to be kept on the enemy. This change in operational tempo and tactics demanded the return, full-circle, to the aggressive patrols that first spawned trench raids in 1915. For example, when the $116^{\text {th }}$ Battalion attacked during the Amiens offensive, it utilized battle patrols to carry out what could be termed "constant raiding," where aggressive infantry repeatedly attacked, retreated, and attacked from flanks to overcome the enemy positions. The official report described one instance on 13 August where "Later in the day the $116^{\text {th }}$ Battalion steadily penetrated again, and after midnight had established themselves just east of Middle Wood, which was strongly held by nests of Machine Guns...Patrols were sent through the village towards Blucher Wood and met serious opposition. Severe close fighting ensued, and the enemy suffered many casualties. About noon an enemy counterattack drove our patrols back on their resistance line..." ${ }^{, 483}$ The report continued to describe the assault, where on another flank the $52^{\text {nd }}$ Battalion attacked and occupied the village of Damery by the use of minor tactics, employing smoke and

\footnotetext{
${ }^{481}$ LAC, Charles Henry Savage, memoir, Fall 1918.

${ }^{482}$ LAC, WD $28^{\text {th }}$ Infantry Battalion, 6 May 1918. See also Toland, 400.

${ }^{483}$ LAC, RG9, v.3858, 82/8, "Summary of Minor Operations on Front of $3^{\text {rd }}$ Canadian Division, Aug 12-15 Inclusive" 15 August 1918.
} 
rifle grenades to assault the German positions. ${ }^{484}$ The Canadians carried out, in essence, "constant" minor operations, adapting a static trench tactic to fight in rapid mobile warfare where there were no trenches. ${ }^{485}$

After Amiens, the Canadians continued to stay on the attack, forging ahead swiftly behind the retreating German army. At the Canal du Nord in late September, nightly combat patrols were carried out along the front in order to hold the line and to gather information on German strongpoints. ${ }^{486}$ In October, as the Canadians pursued the retreating Germans from one village to the next, they carried out modified raiding tactics, utilizing strong screening combat patrols, supported by artillery and mobile machine guns, to forge ahead, capture ground, and to regain contact with the rapidly retreating enemy. These patrols also were to find out any weak points in the enemy line, so a subsequent attack could capitalize on that weakness and pursue the enemy. ${ }^{487}$ As the Germans began retreating at an accelerated pace in late October and early November, the Canadians had to adapt their offensive strategy once more. Their strong patrols and artillery combination, although extremely swift moving compared to combat just four months previously, was still not fast enough to regain contact with the enemy's rearguard sections after the main body of the enemy had retreated during the night. General Currie therefore ordered his troops to not become decisively engaged with the enemy, using patrols and screens of mobile machine gun carriers, armoured cars, and cavalry to shield the rapidly advancing infantry platoons. ${ }^{488}$ Experience in raiding once more aided the main battle, as the basic premise of a raid was to attack, overcome the enemy, but not to be engaged so heavily as to

\footnotetext{
${ }^{484}$ Ibid.

${ }^{485}$ Schreiber, 127. See also Overseas Military Forces of Canada (hereafter referred to as OMFC). Report of the Ministry, 1918. (London: Minister Overseas Military Forces of Canada, 1919), 150.

${ }^{486}$ OMFC, Report of the Ministry, 154-155.

${ }^{487}$ Schreiber, 118. See also OMFC, Report of the Ministry, 171-172.

${ }^{488}$ Ibid, 127.
} 
hamper a speedy withdrawal back to friendly lines. Currie took these operational goals and applied them to his new tactic of steadily pushing against the enemy's contracting lines. ${ }^{489}$ The Hundred Days Campaign was characterized, most often, by open warfare that saw the Canadians rely heavily on these battle patrols. Essentially, in the final stages of the Great War, raids made one final evolution: from "butcher and bolt" to "butcher and advance."

${ }^{489}$ OMFC, Report of the Ministry, 171. 


\section{Conclusion}

The development of Canadian trench raiding from 1915 to 1918 is fundamental to understanding the experience of warfare on the Western Front. Raiding in the Canadian Corps developed tactics, weaponry, command and control, and had an impact on the psychology of the infantryman's wartime experience. These minor operations also shaped the Canadian soldier's conception of peace and violence on the battlefield, morality and killing in combat, fear and bravery, and morale and the will to fight. Trench raiding was influential in almost all facets of the Canadian combat experience on the Western Front.

The first era of raiding saw the evolution of aggressive patrols into well planned trench raids. Elite units such as the $7^{\text {th }}$ Battalion on 15 November 1915 went into No Man's Land to attack the enemy, and paved the way for future battalions to follow suit. In an effort to strike back against a largely unassailable enemy, these innovative trench raids also had a dramatic effect upon the notion of live and let live. By fostering aggression and retaliation, trench raids served as a counter-force to notions of peace on the battlefield. To commanders like General Sir Douglas Haig, raiding became a significant part of the solution to combat peace and lack of offensive activity within the BEF, and to carry out a constant war of attrition against the enemy. Raids thus were systematized and standardized by 1916, which marked their transition from an expression of elite ethos to that of standardized doctrine, and in doing so created a wealth of opportunities for experimentation and tactical innovation. These early raids, usually stealth enterprises, provided the infantry, artillery, signals, and engineer corps with an arena to test and perfect tactical doctrine in the constant search to overcome the primacy of the defensive.

Despite these operational benefits, the systematization of raids had its drawbacks as well: the element of surprise was diminished due to the fact that the enemy often expected raids, and 
there was a danger as competition among Canadian units led them to carry out increasingly dangerous and risky operations. The gathering of intelligence was a key objective of trench raiders, with the goal of determining enemy positions, dispositions, strengths, and a host of other key bits of tactical information. Raiders also secured prisoners to be interrogated, even though in doing so sometimes the rules of war were bent, or ignored outright, and prisoners were killed in the heat of battle. By the time of the 1916 Battle of the Somme, raiding had become the de-facto laboratory of tactical and technological experimentation for trench warfare. Concepts like the creeping barrage, small-unit tactics, rifle-grenade barrages, or advanced communications and signals networks were tested and perfected in trench raids before their use in the big shows.

After the Somme, raiding underwent an operational evolution, progressing through its second era, the lessons from which would be applied to larger offensives in 1917. The key development of the battle raid, such as the $1^{\text {st }}$ C.M.R. Lille Road raid of 20 December 1916, where the raiders attacked in daylight with a large force of men over a wide front, were vital laboratories of practice and experimentation for battle tactics. Command, eager to right the wrongs committed at the Somme, participated in a thorough examination of trench raids throughout the first half of 1917, engaging in a discourse with lower levels of command in order to improve all aspects of the infantry attack. This period also saw the rise of specialized infantry often employing rifle grenades, Lewis guns, and Stokes bombs, and practice with these vital weapons during raids would late pay dividends in larger assaults. Patrols also found prominence during this era, for their utility in flanking and screening raiding parties was invaluable in making sure the attack was informed and protected. These lessons learned were applied to the critical battles of 1917 , where infantry were increasingly able to overcome the primacy of the defensive with innovations in tactics and weaponry. 
Cooperation with artillery, a vital component to overcoming the deepened German defensive systems in 1917 and 1918, was tested, experimented, and honed in the many minor offensive actions. Raids also allowed new recruits to gain vital experience in battle, so that they were hardened combat soldiers by the time the next major set-piece battle emerged. John Becker, a private of the $75^{\text {th }}$ Battalion, remembered one incident when, "our boys made a raid on his trenches. They were able to do a tremendous amount of damage. We had light casualties...Several of our boys were new men. It was a crucial experience for them because it was their first time in the battle line. ${ }^{, 490}$ As the $5^{\text {th }}$ C.M.R.'s Sergeant Charles Savage noted, "Experience was a soldier's best friend, for the longer a man succeeded in keeping alive in the trenches, the better were his chances of continuing in that more or less fortunate condition." ${ }^{\text {,491 }}$

However, not all raids ended in success, and the heavy losses that resulted from failed raids impacted negatively upon the morale and fighting spirit of men and their units. The failure of many raids due to poor planning or logistical preparation, poor intelligence gathering, communications, out of control competition for regimental pride, or by sheer bad luck took their toll on the survivors. The resentment of raiding is perhaps is best summed up by Private Becker, who had this to say about a failed raid: "And what was it all for? Our Battalion alone had lost almost 100 killed and wounded. We had 4 or 5 prisoners and had killed a number but I don't believe the enemy loss was half ours. The idea was to get identification and to wear down their defence in preparation for a general attack...however it was actually just one of those many crazy ideas that cost us men and wore ourselves out. No one will ever convince me that the raid did us any good whatever." ${ }^{492}$ To many of the soldiers tasked with storming the enemy trenches and engaging in violent hand-to-hand combat night after night, trench raids might have seemed to be

\footnotetext{
${ }^{490}$ Becker, 118.

${ }^{491}$ CLIP, Charles Henry Savage, memoir, 1916.

${ }^{492}$ Becker, 82.
} 
wasteful and foolhardy enterprises with no larger goal other than to enforce high command's policy of attrition. Indeed, many good soldiers died in minor operations that did not influence the immediate strategic situation. The soldiers might have snickered at the objectives of some raids, especially those that were to "stimulate the fighting spirit," "demonstrate dominance over the enemy," or "bloody the men," yet the battlefield perspective of the veteran trench soldier was vastly different than that of the general in high command. These soldiers, of course, also did not have the benefit of hindsight 95 years later, and thus could not see how these operations had an impact on the multiple facets of war-fighting on the Western Front.

Raiding never stopped developing from 1915 to the summer of 1918. Even during the Hundred Days, which saw the restoration of the war of movement that largely negated the value of raids, once again raiding tactics were adapted to suit the battlefield environment. In these final months of the war, the raid evolved full-circle into aggressive combat patrols, reminiscent of those that were undertaken in 1915, but with significant differences: the combat patrols during the Hundred Days were infused with all the lessons learned in raiding pertaining to tactics, weaponry, communication, and logistics to make the infantry into self-sufficient, heavily armed combat units that were capable of tackling enemy strongpoints and machine gun nests. The assaults on towns such as Valenciennes and Mons featured small-unit tactics quite similar to those carried out during trench raids, except instead of attacking and retreating back to the safety of friendly lines, the Canadian troops kept forging ahead in a spirit of continuous raiding, a variation on the Australian "peaceful penetration." Trench raids were one of the foundations which enabled the Canadian Corps to grind out victory. Raiding might not have delivered the knockout-blow for the Canadian infantry, but it was one of the main reasons the final punches were as hard-hitting as they were. 
In summation, raiding had a tremendous impact on the tactical and technological development of the Canadian infantryman's experience on the battlefield. Despite the hard lessons and losses from the raids, their influence, when taken as a whole throughout the war, was a positive one for the Canadian Corps. Without the lessons learned from raids, the experimentation in weaponry, from grenades, knives, rifle grenades, and Lewis guns, to major arms such as trench mortars, heavy artillery, and machine guns, would have had to be learned in the episodic major battles, where the stakes were much higher, the troop concentrations denser, and the chance of disaster more likely. These "butcher and bolt" operations were therefore a very important factor in the development of the Canadian attack doctrine, and were especially critical in shaping the Canadian Corps' well-deserved reputation as an elite fighting force. 
Bibliography

Survey Literature

Cook, Tim. Clio's Warriors: Canadian Historians and the Writing of the World Wars. Vancouver: UBC Press, 2006.

Davis, Paul K. 100 Decisive Battles: From Ancient Times to the Present - The World's Most Major Battles and How they Shaped History. New York: Oxford University Press, 1999.

Jones, Archer. The Art of War in the Western World. Chicago: University of Illinois Press, 2001.

Keegan, John. A History of Warfare. Toronto: Vintage Canada, 1993.

Keegan, John. Face of Battle: A Study of Agincourt, Waterloo, and the Somme. London: Pimlico, 2004.

Secondary Literature

i) Strategy, Tactical Doctrine, Weaponry and Technology

Emme, Eugene. M. "Technical Change and Western Military Thought: 1914-1945" Military Affairs, Vol. 24, No.1 (Spring, 1960): 6-19.

Engen, Robert. " Steel Against Fire: The Bayonet in the First World War." Journal of Military and Strategic Studies, Vol. 8, No. 3 (Spring 2006)

Foley, Robert. "What's in a Name: The Development of Strategies of Attrition on the Western Front 1914-18"' The Historian, Vol. 68, No. 4 (2006): 722-746

Griffith, Paddy. Battle Tactics of the Western Front. London: Yale University Press, 1994.

Liaropoulos, Andrew N. "Revolutions in Warfare: Theoretical Paradigms and Historical Evidence: The Napoleonic and First World War Revolutions in Military Affairs" The Journal of Military History, Vol. 70, No. 2 (Apr., 2006): 363-384.

Miedema, Aaron. T. Bayonets and Blobsticks: The Canadian Experience of Close Combat 19151918. Unpublished MA Thesis: Royal Military College of Canada, 2010.

Overseas Military Forces of Canada. Report of the Ministry, 1918. London: Minister Overseas Military Forces of Canada, 1919.

Rawling, Bill. Surviving Trench Warfare. Toronto: University of Toronto Press, 1992.

Rawling, Bill. "Communications in the Canadian Corps, 1915-1918." Canadian Military History, Vol. 3, No. 2, (Autumn 1994), 6-21. 
Todd, Frederick. P. "The Knife and Club in Trench Warfare, 1914-1918" The Journal of the American Military History Foundation, Vol. 2, No. 3 (Autumn, 1938): 139-153.

ii) Combat Motivation and Live and Let Live

Ashworth, Tony. Trench Warfare: The Live and Let Live System. London: Pan Macmillan Ltd., 1980.

Cook, Tim. "The Politics of Surrender: Canadian Soldiers and the Killing of Prisoners in the Great War", The Journal of Military History, Vol. 70, No. 3 (Jul., 2006): 637-665.

Van Bergen, Leo. Before My Helpless Sight: Suffering, Dying, and Military Medicine on the Western Front, 1914-1918. Aldershot: Ashgate, 2009.

Watson, Andrew. Enduring the Great War. New York: Cambridge University Press, 2008.

iii) Regimental and Divisional Histories

Bennett, Stewart. G. The $4^{\text {th }}$ Canadian Mounted Rifles 1914-1918. Toronto: Murray Printing Co. Ltd., 1926.

Fetherstonhaugh, Robert. C., Ed. The $13^{\text {th }}$ Battalion: Royal Highlanders of Canada 1914-1918. Canada: Royal Highlanders, 1925.

Fetherstonhaugh, Robert. C., Ed. The 24th Battalion, CEF, Victoria Rifles of Canada 1914-1919. Montreal: Gazette Printing Co., 1930.

Hayes, Joseph. The Eighty-Fifth in France and Flanders. Halifax: Royal Print \& Litho Ltd., 1920.

Hodder-Williams, Ralph. Princess Patricia's Canadian Light Infantry, 1914-1919. Edmonton: Executive Committee PPCLI, 1968.

Iarocci, Andrew. Shoestring Soldiers: The First Canadian Division at War, 1914-1915. Toronto: University of Toronto Press, 2008.

McWilliams, James. L., and R. James. Steel. Suicide Battalion: $46^{\text {th }}$ South Saskatchewan. Edmonton: Hurtig Publishers, 1978.

Murray, W.W. The History of the $2^{\text {nd }}$ Canadian Battalion (East Ontario Regiment) Canadian Expeditionary Force in the Great War. Ottawa: Mortimer Ltd., 1947.

Radley, Kenneth. We Lead, Others Follow: First Canadian Division 1914-1918. St. Catherines: Vanwell Publishing Ltd., 2006. 
Shackleton, Kevin. R. Second to None: The Fighting $58^{\text {th }}$ Battalion of the Canadian Expeditionary Force. Totonto: Dundun Press, 2002.

iv) Raid Case Studies

Cook, Tim. "A Proper Slaughter: The March 1917 Gas Raid at Vimy", Canadian Military History, Vol. 8, No. 2 (1999): 7-24.

Godefroy, Andrew. "A Lesson in Success: The Calonne Trench Raid, 17 January 1917", Canadian Military History, Vol. 8, No. 2 (1999): 25-34.

Reynolds, Ken. "Under the Cover of Darkness: The Canadian Trench Raid of 8-9 June 1917" In Fortune Favours the Brave: Tales of Courage and Tenacity in Canadian Military History, edited by Bernd Horn, 143-174. Toronto: Dundurn Press, 2009.

Senior, Michael. "Raids and Patrols: What's the Difference?", The Western Front Association: Stand To!, No.89, (August/September 2010), 9-11.

v) History of the Great War on the Western Front

Bean, Charles. E.W. Anzac to Amiens. Canberra: Australian War Memorial Press, 1946.

Cook, Tim. At the Sharp End: Canadians Fighting the Great War 1914-1916. Toronto: Penguin, 2007.

Cook, Tim. Shock Troops: Canadians Fighting the Great War 1916-1918. Toronto: Penguin, 2008.

Cook, Tim. The Madman and the Butcher: The Sensational Wars of Sam Hughes and General Arthur Currie. Toronto: Penguin, 2010.

Dennis, Peter. and Jeffrey Grey, ed. 1917: Tactics, Training, and Technology. Australian Military History Publications, 2007.

Ekins, Ashley, ed. 1918: Year of Victory: The End of the Great War and the Shaping of History. Auckland: Exile Pub. Ltd., 2010.

Gwyn, Sandra. Tapestry of War: A Private View of Canadians in the Great War. Toronto: Harper Collins Ltd., 1992.

Granatstein, Jack, and Desmond Morton. Marching to Armageddon: Canadians and the Great War 1914-1918. Toronto: Key Porter Books, 1989.

Gudmundsson, Bruce. Stormtroop Tactics: Innovation in the German Army: 1914-1918. New York: Praeger Publishers, 1989. 
Harris, J.P. Douglas Haig and the First World War. New York: Cambridge University Press, 2008.

Jenkins, Dan R. Winning Trench Warfare: Battlefield Intelligence in the Canadian Corps, 19141918. Unpublished PhD. Thesis, Carleton University, 1999.

Jenkins, Dan R. "Other Side of the Hill: Combat Intelligence in the Canadian Corps, 19141918." Canadian Military History, Vol. 10, No. 2 (2001), 7-26.

Junger, Ernst. Storm of Steel. London: Penguin, 1961.

Keegan, John. The First World War. London: Random House Ltd., 2001.

Macintyre, Donald E. Canada at Vimy. Toronto: Peter Martin Associates, Ltd., 1967.

Morton, Desmond. When Your Number's Up: Toronto: Random House of Canada Ltd., 1993.

Prior, Robin, and Trevor Wilson. The Somme. London: Yale University Press, 2005.

Reid, Walter. Architect of Victory: Douglas Haig. Edinburgh: Birlinn Ltd., 2006.

Schreiber, Shane B. Shock Army of the British Empire: The Canadian Corps in the Last 100 Days of the Great War. London: Praeger, 1997.

Toland, John. No Man's Land: 1918, The Last Year of the Great War. New York: Doubleday \& Company, Ltd., 1980.

Primary Material

i) Letters and Memoirs: Malaspina University, Canadian Letters and Images Project (CLIP)

Adamson, Agar. Letters, 1914-1918.

Andrews, Alfred Herbert John. Diary, 1914-1918.

Blake, Herbert Percy. Letter to Miss Blake, March 5, 1917.

Bracewell, Maurice Wilfred. Memoir, 1917.

Hampson, Sidney Thomas. Diary, 1915.

McNaughton, John Leslie. Letter to Stuart, March 20, 1917.

Matthews, Cuthbert King. Letter to Mother, June 11917.

Savage, Charles Henry. Memoir, 1915-1918. 
Thorburn, Howard Beverly. Letter to Dad, August 12, 1917.

ii) War Diaries, Digitized: Library and Archives Canada [LAC]

$2^{\text {nd }}$ (Eastern Ontario Regiment) Infantry Battalion, 1915-1918.

$4^{\text {th }}$ (Central Ontario) Infantry Battalion, 1915-1918.

$7^{\text {th }}\left(1^{\text {st }}\right.$ British Columbia) Infantry Battalion, 1915-1918.

$8^{\text {th }}\left(90^{\text {th }}\right.$ Regiment) Infantry Battalion, $1915-1918$.

$10^{\text {th }}$ (Canadians) Infantry Battalion, 1915-1918.

$13^{\text {th }}$ (Royal Highlanders of Canada) Infantry Battalion, 1915-1918.

$14^{\text {th }}$ (Royal Montreal Regiment) Infantry Battalion, 1915-1918.

$19^{\text {th }}$ Infantry Battalion.

$20^{\text {th }}$ Infantry Battalion.

$21^{\text {st }}$ Infantry Battalion.

$24^{\text {th }}$ (Victoria Rifles) Infantry Battalion, 1915-1918.

$25^{\text {th }}$ (Nova Scotia Rifles) Infantry Battalion, 1915-1918.

$27^{\text {th }}$ (Winnipeg) Infantry Battalion, 1915-1918.

$28^{\text {th }}$ (Northwest) Infantry Battalion, 1915-1918.

$29^{\text {th }}$ (Vancouver) Infantry Battalion, 1915-1918.

$31^{\text {st }}$ (Albertan) Infantry Battalion, 1915-1918.

$42^{\text {nd }}$ (Royal Highlanders) Infantry Battalion, 1915-1918.

$43^{\text {rd }}$ (Cameron Highlanders) Infantry Battalion, 1915-1918.

$44^{\text {th }}$ (Manitoba) Infantry Battalion, 1915-1918.

$46^{\text {th }}$ (South Saskatchewan) Infantry Battalion, 1916-1918.

$49^{\text {th }}$ (Edmonton) Infantry Battalion, 1916-1918. 
$54^{\text {th }}$ (Kootenay) Infantry Battalion, 1915-1918.

$58^{\text {th }}$ Infantry Battalion, $1916-1918$.

$72^{\text {nd }}$ (Seaforth Highlanders of Canada) Infantry Battalion, 1916-1918.

$85^{\text {th }}$ (Nova Scotia Highlanders) Infantry Battalion, 1916-1918.

$102^{\text {nd }}$ (North British Columbia) Infantry Battalion, 1916-1918.

$1^{\text {st }}$ CMR, 1915-1918.

$2^{\text {nd }} C M R, 1915-1918$.

$4^{\text {th }}$ CMR, 1915-1918.

$5^{\text {th }}$ CMR, 1915-1918.

Princess Patricia’s Canadian Light Infantry [PPCLI], 1914-1918.

iii) Battalion/Brigade/Division/Corps Minor Operations Folders RG9 / RG24 [LAC]

RG9, v.3858

RG9, v.3859

RG9, v.3865

RG9, v.3915

RG9, v.3925

RG9, v.3984

RG9, v.3995

RG9, v.4016

RG9, v.4017

RG9, v.4028

RG9, v.4040

RG9, v.4052 
RG9, v.4053

RG9, v.4061

RG9, v.4065

RG9, v.4106

RG9, v.4140

RG9, v.4148

RG9, v.4149

RG9, v.4154

RG9, v.4199

RG9, v.4208

RG9, v.4286

RG9, v.4319

RG9, v.4690

RG9, v.4699

RG24, v.1865

iv) Published Memoirs / Diary Collections

Bagnall, Fred. Not Mentioned in Dispatches: The Memoir of Sgt. Fred Bagnall, $14^{\text {th }}$ Battalion CEF: 1914-1917. Ottawa: CEF Books, 2005.

Becker, John H. Silhouettes of the Great War: The memoir of John Harold Becker, $75^{\text {th }}$ CEF, 1914-1918. Ottawa: CEF Books, 1998.

Bird, Will. Ghosts Have Warm Hands. Toronto: Clarke, Irwin, \& Co. Ltd., 1968.

Black, Ernest G. I Want One Volunteer. Toronto: Ryerson, 1965.

Blunden, Edmund. Memoirs of an Infantry Officer. London: 1930. 
Burns, Eedson L.M. General Mud: Memoirs of Two World Wars. Toronto: Clarke, Irwin \& Co. Ltd., 1970.

Canadian Bank of Commerce, Letters from the Front, Being a Record of the Part Played by Officers of the Bank in the Great War, 1914-1919, Volume 1. Canadian Bank of Commerce Press, 1920.

Christie, Norm M., ed. Letters of Agar Adamson: 1914-1919. Ottawa: CEF Books, 2008.

Cooke, Bert. We're Not Dead Yet: The First World War Diary of Bert Cooke. Edited by Milly Walsh and John Callan. St. Catherines: Vanwell Pub., 2005.

Fraser, Donald. The Journal of Private Fraser 1914-1918: Canadian Expeditionary Force. Victoria: Sono Nis Press, 1985.

Peat, Harold R. Private Peat. New York: Grosset and Dunlap Pub., 1917.

Pedley, James H. Only This: A War Retrospect 1917-1918. Graphic Pub., 1927.

Pope, Maurice. Letters from the Front. Toronto: Pope \& Co., 1993.

Roy, Reginald H, ed. The Journal of Private Fraser, 1914-1918, Canadian Expeditionary Force. Victoria: Sono Nis Press, 1985.

Sassoon, Siegfried. Undertones of War. London: 1928.

v) Unpublished Diary Collections / Memoirs [LAC/CWM]

CWM, 1980 1226-286 58 A 1.62.1, Currie papers, 1914-1918.

MG30 E241, D.E. Macintyre papers, diary, 1915-1918.

vi) Training Manuals [CWM and LAC]

LAC, RG9, v.3858, folder 82, file 1, S.S. 107 "Notes on Minor Operations", General Staff G.H.Q., March 1916. 